KARIN CRISTINA DA SILVA MODENA

INFLUÊNCIA DE MATERIAIS ODONTOLÓGICOS NA CAPACIDADE DE RESPOSTA DE FIBROBLASTOS CULTIVADOS DE POLPA DENTAL HUMANA 

KARIN CRISTINA DA SILVA MODENA

\section{INFLUÊNCIA DE MATERIAIS ODONTOLÓGICOS NA CAPACIDADE DE RESPOSTA DE FIBROBLASTOS CULTIVADOS DE POLPA DENTAL HUMANA}

Tese apresentada à Faculdade de Odontologia de Bauru, Universidade de São Paulo, como parte dos requisitos para obtenção do título de Doutora em Odontologia, na área de Dentística Restauradora.

Orientadora: $\operatorname{Prof}^{\mathrm{a}} \operatorname{Dr}^{\mathrm{a}}$ Maria Fidela de Lima Navarro

Versão Corrigida

BAURU

2012 


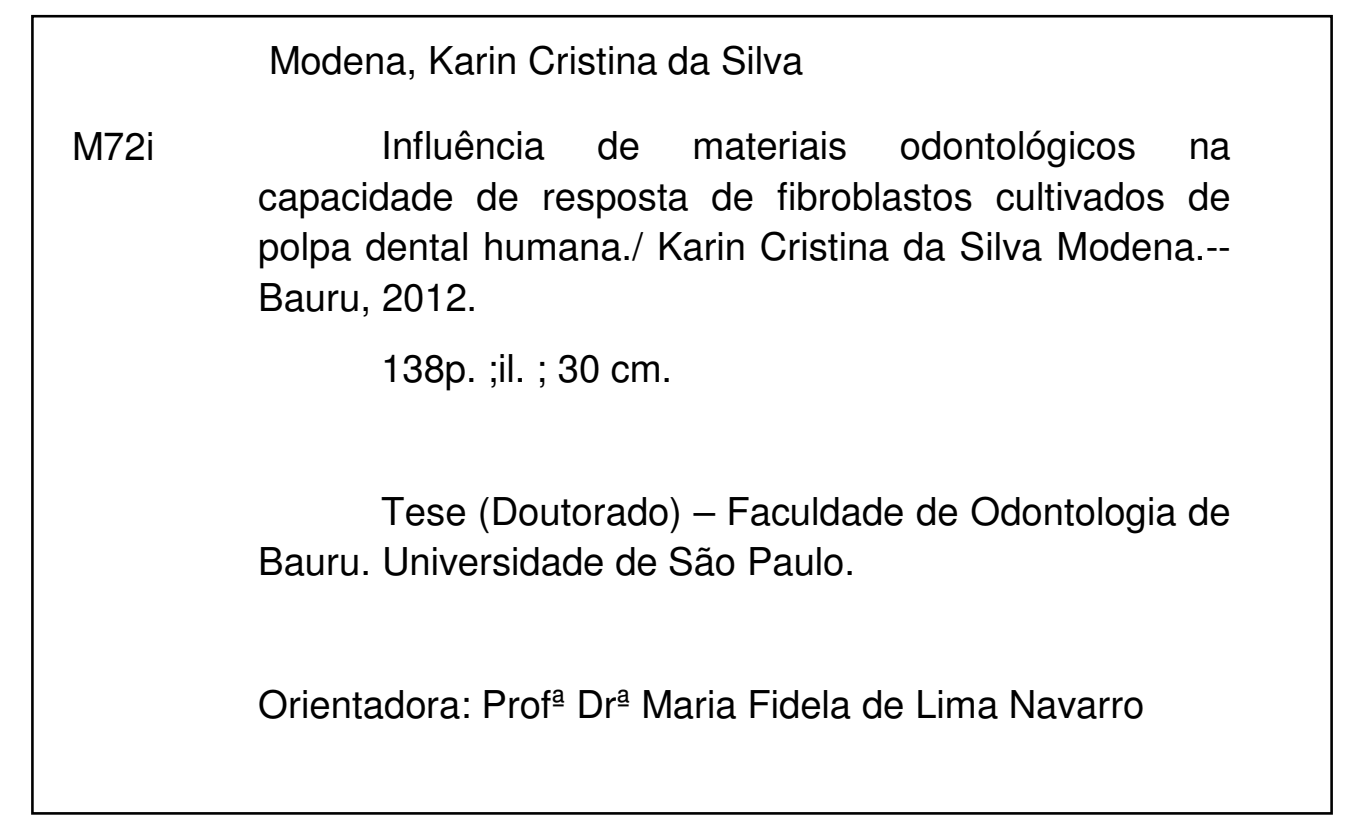

Nota: A versão original desta tese encontra-se disponível no Serviço de Biblioteca da Faculdade de Odontologia de Bauru - FOB/USP.

Autorizo, exclusivamente para fins acadêmicos e científicos, a reprodução total ou parcial desta tese, por processos fotocopiadores e outros meios eletrônicos.

Assinatura:

Data:

Comitê de Ética da FOB-USP

Protocolo no: 137/2007 


\title{
DEDICATÓRIA
}

\begin{abstract}
A Deus,
Por me iluminar e me carregar nos braços para que eu sempre conseguisse ultrapassar e vencer todos os percalços que fazem parte do nosso caminho e nos tornam pessoas mais fortes e corajosas. Por nunca ter me desamparado, embora eu achasse que estivesse sozinha. A cada dia o Senhor me faz crer que tudo o que acontece na nossa vida é para um bem maior, apesar de não entender naquele momento o porquê. Por ter colocado na minha vida vários anjos, em especial tia Cinira, tia Paula, tia Maria e tio Celso, que me acolheram abrindo mão de muitas coisas para cuidar de mim, com todo o amor e dedicação.

\section{Aos meus pais Francisco Aurélio Modena e Renilde da Silva (in memoriam),}

Mesmo que a nossa convivência não tenha sido por muito tempo, me deixaram como ensinamento ter objetivos na vida e a lutar para alcançá-los com dignidade e respeito ao próximo. Estudar, estudar e estudar para ter um futuro melhor era o que meu pai sonhava para mim. Com todo o seu jeito durão por fora, por dentro tinha um coração imenso e sempre se preocupava com a minha felicidade. Pouco tenho a falar da minha mãe porque o nosso convívio foi de apenas 6 anos, o que me lembro era de seu carinho e dedicação por mim e meu pai.

Às minhas tias e tio Maria Elisa Modena Dias Duarte e Celso Dias Duarte (in memoriam), Cinira Antônia Modena e Paulina Modena de Castro,

Não conheço uma família que tenha feito tudo, mais do que tudo por uma sobrinha como vocês. A vocês eu devo tudo o que sou até agora. Tia Maria e tio Celso, com quem eu fui morar no início, não mediram esforços para que eu me sentisse acolhida e amada. De uma bondade e carinho imensuráveis, tio Celso me tratava como mais que uma filha, como uma boneca que precisava de todo o cuidado e mimo e tia Maria que deixou a vida tranquila que a aposentadoria lhe proporcionara para voltar a ser mãe e ter todo o trabalho que duas crianças dão. Após minhas férias de colégio, não quis voltar para casa e fiquei, sem pedir permissão, morando com a Tia Cinira e tia Paula, que a partir de então, foram e são minha mãe e pai.
\end{abstract}



Elas escreveram uma mensagem que me tocou profundamente e não posso deixar de compartilhar: "Lembre-se sempre: só temos uma vida para viver: a nossa. Procure nortear a sua pelo amor, honestidade, discernimento, solidariedade, etc. Daqui a anos, a efemeridade da existência vai fazê-la lembrar com saudade das tias que sempre lhe desejaram o melhor dos mundos e almejaram ardentemente que todo dia seja dia para que você seja muito feliz.” Esta foi uma das maiores demonstrações de amor que já recebi. Vocês me deram educação, carinho, amor, conforto, me ensinaram valores que levarei para o resto de minha vida. Tia Cinira abriu mão de muitos sonhos para se dedicar a mim, com um amor incondicional, passou por cima de muitas coisas para atender aos meus desejos. Tia Paula, com seu jeito meigo, sempre com uma palavra de conforto e carinho me ensinou que o amor é possível e com ele no coração a vida se torna mais fácil. Sem vocês eu não teria estudado, me formado numa ótima universidade e agora concluído mais essa fase. A vocês, minha eterna gratidão por terem me proporcionado uma vida maravilhosa, por me acolherem e por suportarem os meus momentos de adolescente que vocês não tinham obrigação de fazê-lo, mas, que o que imperou foi o amor por mim. 

"Tu não temerás os terrores noturnos nem a flecha que voa à luz do dia nenhum mal te atingirá porque aos seus anjos ele mandou que te guardem em todos os seus caminhor" Salmo 90 



\section{AGRADECIMENTOS}

\section{À MINHA FAMÍLIA}

À minha irmã Aline Modena,

Obrigada querida irmã, por tua atenção, dedicação, carinho e paciência. Este é o amor puro e sincero, sem interesse algum, o amor fraterno.

Ao meu irmão e família Marco Antônio Modena, Maria Ângela, Maria Estela e Maria Angélica,

Pelos momentos agradáveis que passamos juntos, pelo carinho que sempre tiveram conosco e pela torcida.

Aos meus tios Ezídio Modena e Joana,

Pelo incentivo e apoio constantes, pelos prazerosos momentos que passei na sua casa, com meus primos.

À minha segunda família, Artur Modena, Rosana, dona Maria (in memoriam) e seus filhos Patrícia, Diego, Danielle e Rodrigo,

Vocês sempre tiveram um carinho imenso por mim e estavam presentes em todos os momentos alegres e tristes da minha vida. A filha "branca", como vocês me chamam, só tem a agradecer o amor, o afeto, a confiança e a preocupação que demonstram toda a vez que nos encontramos. Infelizmente a distância nos separa, mas, com certeza os nossos corações estão conectados. Amo vocês.

Ao meu padrinho Antonio Celso, Rosângela e Rafael,

Por vocês sempre se preocuparem comigo desde a infância. Sempre me deram conselhos para que eu seguisse o melhor caminho. Cada abraço apertado que recebo é como se fosse uma carga de energia boa. Padrinho, você é um exemplo de pessoa e de profissional a ser seguido. Vocês também fazem parte de mais essa vitória na minha vida. 

Ao meu grande companheiro, Marco Antonio (Marquinho),

Pela pessoa maravilhosa e admirável que você é, tudo o que eu sempre pedi a Deus: companheiro, carinhoso, paciente, atencioso e trabalhador. Com você aprendi que com trabalho, humildade, perseverança e paciência podemos atingir nossos objetivos. Espero que juntos, um pelo outro, possamos conseguir ter uma vida de muitas alegrias e conquistas. $\mathrm{O}$ companheirismo, o cuidado que você tem por mim, o carinho imenso e a confiança que você passa me faz querer que essa união permaneça por muito tempo.

\section{AOS MeUS MESTRES,}

\section{À minha orientadora $\operatorname{Prof}^{a} \operatorname{Dr}^{a}$ Maria Fidela de Lima Navarro,}

Meu agradecimento eterno pela oportunidade de trabalharmos juntas, de conhecer outros países, grande sonho da minha vida, apoiando a minha ida a congressos e por passar tantos momentos agradáveis e divertidos ao seu lado. A senhora é um exemplo de pessoa dedicada e batalhadora. Os seus ensinamentos ficarão para a vida toda. Nunca me esquecerei de que devemos olhar pra frente e esquecer o que passou porque não pode ser mudado: "bola pra frente, santinha", e que pra tudo tem uma saída. Muito obrigada por ter feito parte da minha vida.

\section{Ao prof. Carlos Ferreira dos Santos,}

Como eu sempre digo, você foi um dos anjos que Deus colocou na minha vida. Desde os meus devaneios na graduação de querer trabalhar com fitoterápicos (??), nunca me disse "não", só me encaminhou para as melhores decisões. Não tenho palavras para agradecer tudo o que tem feito por mim desde 2003. Suas palavras de carinho sempre me marcaram muito: "Calma fia, tudo tem seu tempo" e "Nada acontece por acaso, Papai do Céu sabe de todas as coisas". Você é uma pessoa iluminada, sempre me socorreu nos momentos de dificuldade às vezes sem eu mesma pedir, simplesmente sentia e você percebe os meus sentimentos sem eu ter que dizer nada.

\section{À querida prof ${ }^{a}$ Maria Teresa Atta,}

Muito obrigada pela paciência com que sempre me recebeu, fosse para ouvir os meus problemas pessoais (que foram muitos) ou responder às minhas dúvidas de projetos 

de pesquisa, artigos, Comitê de Ética, etc. Com seus conselhos sábios me fez abrir os olhos em várias ocasiões, enxergar tudo de uma maneira diferente e aceitar que o sofrimento é inevitável e faz parte do nosso aprendizado. Você é uma pessoa maravilhosa por dentro e por fora, além de uma ótima professora, é a grande amiga que ficará guardada no meu coração para sempre.

\section{À prof ${ }^{\mathrm{a}}$ Linda Wang,}

O seu entusiasmo pelo trabalho é contagiante. Muito obrigada pelo convite para participar do seu grupo de pesquisa, me senti muito lisonjeada. Espero poder contar com a sua parceria e apoio em outros projetos. Você é um exemplo de competência, garra e força de vontade. Tenho muito que aprender com você ainda. Obrigada pelo carinho que sempre demonstrou por mim e pela paciência nos momentos em que eu estava mais atarefada e tinha várias coisas em débito com você.

\section{Ao querido prof José Mondelli,}

Tenho muito que agradecer o carinho de pai com que o senhor me tratou desde o momento em que ficou sabendo da minha história de vida, e se propôs a ajudar-me no que eu precisasse. Foi pelo senhor que resolvi partir para a área de Dentística, porque até então meu desejo era ser Cirurgiã Buco-Maxilo Facial. Muito obrigada por todos os ensinamentos, momentos na clínica integrada restauradora e clínicas de especialização. Quero eu sentir metade do amor que o senhor sente pela Odontologia.

Aos professores Flavio Cardoso Faria, Aquira Ishiquiriama, Sérgio Kiyoshi Ishiquiriama, Paulo Afonso Silveira Francisconi, José Carlos Pereira, Eduardo Batista Franco, Rafael Francisco Lia Mondelli, Acácio Lins do Valle e Carlos Eduardo Francischoni,

Meus agradecimentos pelo carinho e prontidão com que sempre me receberam, pelo apoio e ajuda que me deram nos momentos que passei na FOB, tanto na graduação quanto na pósgraduação. Vocês são mais que professores formando dentistas, são formadores de opinião, passando aos seus alunos valores como respeito ao próximo e honestidade. Além disso, amam o que fazem e isso é um estímulo para nós, que estamos iniciando na carreira. Tão importante quanto o ensino de uma profissão, são os ensinamentos de vida que levamos para sempre. 



\section{AOS MeUs AMigos}

\section{À minha irmã japonesa Cintia Nishida,}

Você também foi um dos anjos que Deus colocou na minha vida. Nunca eu tinha tido uma amiga tão dedicada como você. Muito obrigada por me ouvir e segurar a minha "barra" nos momentos de dificuldade. Embora eu não estivesse nos meus melhores dias, você nunca me deixou. A nossa cumplicidade é tanta que sabemos o que está acontecendo apenas com um olhar. Compartilhamos momentos de muitas alegrias e vitórias. Você é uma pessoa de extrema bondade, querida por todos, o que me causa certo ciúme. Muito obrigada por me aceitar com todos os defeitos que possuo e continuar sendo minha grande amiga. À tia Neuzinha pelo enorme carinho e amizade, pelas comidas japonesas maravilhosas e por me receber em sua casa sempre com um sorriso no rosto. Assim como a Cintia, a senhora possui um coração de ouro.

\section{À Adriana Calvo, Bella Luna Colombini Ishikiriama e Flavia Nashan,}

Minhas grandes amigas de todas as horas. Sempre estiveram ao meu lado para tudo e sei que posso contar com vocês para qualquer coisa. Com vocês aprendi o que é ser e ter uma amiga de verdade. Porque os verdadeiros amigos gostam de você do jeito que você é, com todos os seus defeitos e qualidades, assim como sua família. Com amigas como vocês meus dias se tornaram melhores em Bauru. Bella, fico extremamente feliz por olhar para trás e ver a evolução da nossa amizade. O passar dos anos nos fez amadurecer e ver que a amizade é um dos bens mais importantes que levamos dessa vida. Vocês tomaram um pedaço no meu coração e conforme o tempo passa, percebemos quem são os verdadeiros amigos, aqueles que podemos chamar de irmãos. Sou muito grata por vocês me quererem tão bem e cada uma de vocês é única e nenhuma substitui a outra.

\section{À Luana Mendonça,}

Amiga, nunca vou esquecer-me do que me ensinou no ano passado. Isso foi um marco muito grande na nossa amizade. Você é uma pessoa maravilhosa que eu quero muito bem e tenho um carinho especial. Às vezes o ciúme tomava conta de mim e eu não conseguia enxergar que podia nascer uma amizade verdadeira entre nós. Você também sempre vai morar no meu coração, mesmo que a distância nos afaste. É por isso que destino existe, é por isso que nós não nos encontramos por acaso. 



\section{À minha roommate Dayane Kemp,}

A nossa amizade surgiu depois da graduação, com a sua volta a Bauru. Muito obrigada pela paciência que você está tendo nesse período da minha vida, a minha gratidão é imensa por isso. Nós compartilhamos as nossas vidas, sonhos, medos, erros e sempre você teve palavras de apoio e conselhos. Além de darmos boas risadas com as histórias engraçadíssimas que você tem. Obrigada de todo o meu coração.

Aos meus amigos queridos Gustavo e Adriana, Luciana Mendonça e Leandro Martins, Max Dória e Luiz Alves,

Pelos vários momentos agradáveis, divertidíssimos e engordativos que passamos juntos no Solar Cristiane. Ter um grupo de amigos quando estamos em outra cidade, sem a nossa família é fundamental, e com certeza vocês alegraram os meus dias.

Às minha amigas das turmas de Mestrado e de Doutorado Leslie Casas-Apayco, Luciana Francisconi, Paula Sampaio, Polliana Scaffa, Ticiane Fagundes, Marcela Calabria e Maria Cristina

Companheiras de clínicas, seminários, viagens, pesquisas...Agradeço por fazerem parte da minha vida, sempre com um sorriso no rosto e prontas para me ajudar em qualquer coisa de que eu precisasse. Quando cada uma seguir o seu caminho (o que já aconteceu com algumas), gostaria que lembrassem que podem contar com a minha amizade a qualquer momento e que possamos nos reencontrar sempre que possível. Vocês fazem muita falta no meu dia-a-dia.

Aos meus amigos da Disciplina de Farmacologia Ana Carolina Morandini, Carla Sipert, Caio Figueiredo, Daniel Brozoski, Fernanda Veronese, Lucimara Teixeira das Neves, Thais Marchini de Oliveira, Thaís Garbieri, Thiago José Dionísio, Viviane Parisi e Vera Rufino,

Todos, de alguma maneira, foram fundamentais para que esse trabalho pudesse se concretizar. Muito obrigada por eu fazer parte desse grupo com pessoas tão queridas que proporcionassem um ambiente de trabalho muito tranquilo e alegre. Sempre que eu precisava, alguém estava pronto para me ajudar. Carla me ensinou muitas partes da metodologia deste trabalho. Carol resolveu muitas das minhas dúvidas e Thiago, fico sem palavras para agradecer as infinitas vezes em que precisei de você, desde a Iniciação Científica. Muito obrigada pela paciência com que sempre me tratou, pelo sorriso no rosto e pelos momentos de 

muita alegria com que você conduzia as pesquisas no laboratório. À Vera, pelo exemplo de mulher batalhadora e forte, pelos maravilhosos bolos que alegravam as nossas tardes, deixando nossa vida um pouco mais doce.

Aos meus amigos Bruna e Pedro, Mário, Jorginho, Déia, Vitor, Massao, Carlessa,

\section{Beta e Camila}

Meus amigos bauruenses, companheiros dos finais de semana. A alegria é garantida quando estamos juntos. Muito obrigada pelo apoio e carinho que sempre demonstraram por mim. Cada um de vocês que passar, quando for embora, vai levar um pedaço de mim, mas comigo vai deixar um pedaço de si.

Existem pessoas que apenas passam por nossas vidas. Porém existem aquelas que acrescentam alegria ao nosso dia-a-dia, nos ajudando a escrever nossa história.

\section{AOS FUNCIONÁRIOS}

Do departamento de Dentística e Endodontia Nelson, Zuleika, Rita, Natália, Elísio, Beth, Ligia e Edimauro,

Departamento de Microbiologia André, Dalva e Livia,

Departamento de Bioquímica Telma e Ovídio,

Do Serviço de Biblioteca e Documentação da FOB/USP,

Da clínica de pós-graduação, Cleusinha e Hebe

Por serem tão prestativos quando precisei, sem qualquer obrigação. Vocês foram os meios para que eu pudesse realizar esse trabalho, desenvolver minhas habilidades atendendo pacientes e resolvendo pequenos problemas que surgem no dia-a-dia. 



\section{AgRADECIMENTOS InSTITUCIONAIS}

Ao Departamento de Ciências Biológicas, Disciplina de Microbiologia, na pessoa da prof $^{a} \operatorname{Dr}^{\mathrm{a}}$ Ana Paula Campanelli e Disciplina de Bioquímica na pessoa da $\operatorname{prof}^{\mathrm{a}} \operatorname{Dr}^{\mathrm{a}}$ Marília Afonso Rabelo Buzalaf,

Por disponibilizar o uso dos equipamentos e funcionários para que esse trabalho pudesse ser realizado.

Às instituições Universidade de São Paulo, na pessoa do Magnífico Reitor Prof Dr João Grandino Rodas, e a Faculdade de Odontologia de Bauru, na pessoa de seu Diretor Prof Dr José Carlos Pereira,

Pelas condições de estudo e pesquisa proporcionadas por esta instituição, que me auxiliaram na realização desse trabalho.

Ao programa de Pós-Graduação em Odontologia da FOB/USP, na pessoa do Prof Dr Paulo César Rodrigues Conti,

Pelo aprimoramento da minha formação superior, tornando-me uma pessoa mais crítica e questionadora.

\section{À Coordenação de Aperfeiçoamento Pessoal de Nível Superior (CAPES),}

Pelo financiamento desse trabalho com a concessão de bolsa de estudos durante todo o período de minha pós-graduação, o que possibilitou a minha permanência em Bauru. 

"Não busco discipulos para comunicar-thes saberes. Os saberes estão soltos por aí, para quem quiser. Busco discipulos para neles plantar minhas esperanças." 



\section{RESUMO}

O presente trabalho tem como objetivo investigar a influência de materiais utilizados na prática odontológica (Single Bond, HEMA, Vitrebond, Ketac Molar e Dycal) na resposta inflamatória de fibroblastos cultivados de polpa dental humana de dentes permanentes em relação à expressão e produção de mediadores da inflamação. As culturas primárias de fibroblastos foram estabelecidas a partir do tecido pulpar de terceiros molares hígidos. Após a quarta passagem, os fibroblastos foram estimulados pelos materiais e pelos materiais seguidos por LPS de E. coli pelos tempos de 6 e 24 horas. Os testes utilizados foram: MTT, Trypan Blue, Análise de Griess, PCR quantitativo e ELISA. Os dados foram analisados estatisticamente aplicando-se o teste ANOVA a 1 critério e pós-teste de Tukey e ANOVA a 2 critérios e teste de correção de Bonferroni ( $\mathrm{p}<0,05)$. Os materiais SB10 (Single Bond 1:100) e DY (Dycal) afetaram a viabilidade celular com diminuição do metabolismo. Os materiais SB1 (Single Bond 1:1.000), SB10 (Single Bond 1:100) e VB (Vitrebond) seguidos de LPS de $E$. coli diminuíram o metabolismo celular de maneira estatisticamente significativa. Os níveis de óxido nítrico produzidos foram diminuídos quando os fibroblastos foram estimulados pelo KM (Ketac Molar). A expressão gênica para pró-colágeno tipo I foi diminuída quando os fibroblastos foram estimulados pelos materiais SB10 (Single Bond 1:100), SB (Single Bond polimerizado) e DY (Dycal). Para o SDF-1 $\alpha /$ CXCL12 houve um aumento da expressão para o grupo estimulado apenas por LPS de E. coli, SB10 (Single Bond 1:100) e DY (Dycal). Para o IL-6 notou-se uma diminuição significativa para o grupo estimulado por H1000 (HEMA $1000 \mathrm{nM}$ ) e um aumento para o grupo SB10 (Single Bond 1:100). A expressão gênica de IL8/CXCL8 diminuiu para os fibroblastos estimulados pelas três concentrações de HEMA e de Single Bond, VB (Vitrebond) e DY (Dycal) no período de 6 horas e houve um aumento para os materiais SB10 (Single Bond 1:100) e VB (Vitrebond) no período de 24 horas. Houve diminuição na secreção de SDF-1 $\alpha /$ CXCL12 para as três concentrações de HEMA e DY (Dycal) e uma tendência de diminuição para os demais materiais testados. A produção de IL-6 foi aumentada para os materiais VB (Vitrebond) e KM (Ketac Molar). A produção de IL8/CXCL8 foi aumentada para SB1 (Single Bond 1:1.000), VB (Vitrebond) e KM (Ketac Molar) e diminuída para SB10 (Single Bond 1:100) e DY (Dycal). O Single Bond e o HEMA, em várias concentrações, diminuíram a expressão e produção de moléculas envolvidas no processo inflamatório e, por causa de seu efeito citotóxico, devem ser vistos com cautela quando em íntimo contato com o órgão pulpar. O hidróxido de cálcio causou intensa morte 

celular e não estimulou a produção dos mediadores da inflamação avaliados neste trabalho, mas esse evento parece ser fundamental para o processo de reparo do tecido pulpar e formação de barreira mineralizada. Os cimentos de ionômeros de vidro utilizados aumentaram a produção de quimiocinas relacionadas ao processo inflamatório, portanto, esses materiais, embora não tenham causado morte de grande número celular, devem ser utilizados com restrições.

Palavras chave: Fibroblasto. Viabilidade celular. Citocina. Quimiocina. Materiais Dentários. 



\section{ABSTRACT \\ Influence of dental materials on the response capability of cultured fibroblasts from human dental pulp}

The aim of the present study is to investigate the influence of dental materials (Single Bond, HEMA, Vitrebond, Ketac Molar e Dycal) in the inflammatory response of human dental pulp fibroblasts from permanent teeth in relation to inflammatory mediators expression and production. Primary cultures were established from third molars pulp tissue. After the fourth passage, the fibroblasts were stimulated only by materials and also by the materials followed by LPS from E. coli for 6 and 24 hours. Data were statistically analyzed using Oneway ANOVA and Tukey post-test and Two-way ANOVA followed by Bonferroni post-test $(\mathrm{p}<0.05)$. SB10 (Single Bond 1: 100) and DY (Dycal) affected cell viability and consequently decreased cell metabolism. SB1 (Single Bond 1:1,000), SB10 (Single Bond 1:100) and VB (Vitrebond) followed by LPS E. coli decreased cell metabolism. Nitric oxide levels were reduced when fibroblasts were stimulated by KM (Ketac Molar). Pro-collagen type I expression was reduced when fibroblasts were stimulated by SB10 (Single Bond 1:100), SB (polymerized Single Bond) and DY (Dycal). SDF-1 $\alpha /$ CXCL12 expression was increased for the group stimulated only by LPS from E. coli, SB10 (Single Bond 1:100) and DY (Dycal). IL-6 expression had a significant decrease in the group stimulated by H1000 (HEMA 1000 $\mathrm{nM}$ ) and an increase for SB10 (Single Bond 1:100) group. The expression of IL-8/CXCL8 decreased when fibroblasts were stimulated by the three concentrations of HEMA and of Single Bond, VB (Vitrebond) and DY (Dycal) at 6 hours and increased for SB10 (Single Bond 1:100) and VB (Vitrebond) at 24 hours. There was decrease in SDF-1 $\alpha / C X C L 12$ production for the three concentrations of HEMA and DY (Dycal) and a declining trend for the other materials tested. The production of IL-6 was increased by VB (Vitrebond) and KM (Ketac Molar). The production of IL-8/CXCL8 increased by SB1 (Single Bond 1:1,000), VB (Vitrebond) and KM (Ketac Molar) and decreased by SB10 (Single Bond 1:100) and DY (Dycal). Single Bond and HEMA, in different concentrations, decreased the production and the expression of molecules involved in the inflammatory process and, because of its cytotoxic, should be viewed with caution when in intimate contact with the pulp tissue. Calcium hydroxide caused intense cell death and did not stimulate the production of inflammatory mediators evaluated, but this event seems to be essential to the pulp tissue 

repair process and mineralized barrier formation. The glass ionomer cements used increased the production of chemokines related to the inflammatory process, therefore, these materials, although they have not caused death of many cells, must be used with restrictions.

Key words: Fibroblast. Cell viability. Cytokine. Chemokine. Dental Materials. 



\section{LISTA DE ILUSTRAÇÕES}

FIGURAS

Figura 1- Fibroblastos de polpa dental humana. A cultura primária foi estabelecida por meio de técnica de explant. Sete dias do início da cultura (A), 14 dias (B), 17 dias (C) e 21 dias (D). Visualização em microscópio óptico invertido com contraste de fases com aumento de $10 \mathrm{X}$.

Figura 2- Ensaio de viabilidade celular (Trypan Blue) dos fibroblastos de polpa dental humana quando estimulados pelos materiais $\mathrm{H} 10$ (HEMA 10 nM), H100 (HEMA 100 nM), H1000 (HEMA 1000 nM), SB 0,1 (Single Bond 1:10.000), SB 1 (Single Bond 1:1.000), SB 10 (Single Bond 1:100) comparados ao grupo controle CLE e VB (Vitrebond), SB (Single Bond), KM (Ketac Molar), DY (Dycal) comparados ao grupo controle CTW. Valores dados em porcentagem de células vivas no período de 6 horas. $*<$ CLE, $\mathrm{p}<0,05 ; \mathrm{n}=3$.

Figura 3- Ensaio de viabilidade celular (Trypan Blue) dos fibroblastos de polpa dental humana quando estimulados pelos materiais $\mathrm{H} 10$ (HEMA 10 nM), H100 (HEMA 100 nM), H1000 (HEMA 1000 nM), SB 0,1 (Single Bond 1:10.000), SB 1 (Single Bond 1:1.000), SB 10 (Single Bond 1:100) comparados ao grupo controle CLE e VB (Vitrebond), SB (Single Bond), KM (Ketac Molar), DY (Dycal) comparados ao grupo controle CTW. Valores dados em porcentagem de células vivas no período de 24 horas. $*<$ que os respectivos controles, $\mathrm{p}<0,05 ; \mathrm{n}=3$.

Figura 4- Citotoxicidade (MTT) dos materiais H10 (HEMA 10 nM), H100 (HEMA 100 nM), H1000 (HEMA 1000 nM), SB 0,1 (Single Bond 1:10.000), SB 1 (Single Bond 1:1.000), SB 10 (Single Bond 1:100) comparados ao grupo controle não estimulado CLE e VB (Vitrebond), SB (Single Bond), KM (Ketac Molar) e DY (Dycal) comparado ao grupo controle CTW, utilizados para estimular fibroblastos de polpa dental humana no período de 6 horas. Valores representativos das médias \pm desvio padrão, $n=3$. Não houve diferença estatisticamente significativa para os grupos estudados 

Figura 5- Citotoxicidade (MTT) dos materiais H10 (HEMA $10 \mathrm{nM}$ ), H100 (HEMA 100 nM), H1000 (HEMA 1000 nM), SB 0,1 (Single Bond 1:10.000), SB 1 (Single Bond 1:1.000), SB 10 (Single Bond 1:100) comparados ao grupo controle não estimulado CLE e VB (Vitrebond), SB (Single Bond), KM (Ketac Molar) e DY (Dycal) comparado ao grupo controle CTW, utilizados para estimular fibroblastos de polpa dental humana no período de 24 horas. Valores representativos das médias \pm desvio padrão. * < que os respectivos controles, $\mathrm{p}<0,05 ; \mathrm{n}=3$.

Figura 6- Citotoxicidade (MTT) dos materiais H10 (HEMA 10 nM), H100 (HEMA 100 nM), H1000 (HEMA 1000 nM), SB 0,1 (Single Bond 1:10.000), SB 1 (Single Bond 1:1.000), SB 10 (Single Bond 1:100), VB (Vitrebond), SB (Single Bond) e KM (Ketac Molar) seguidos por estímulo por LPS de E. coli comparado ao grupo controle CLE, CLE LPS e CTW no período de 24 horas. Valores representativos das médias \pm desvio padrão. $*<$ CLE, CLE LPS e CTW, $<<0,05$. O ensaio foi realizado em triplicata.

Figura 7- Quantidade de nitrito produzida por fibroblastos de polpa dental humana estimulados pelos materiais VB (Vitrebond), SB (Single Bond), KM (Ketac Molar), DY (Dycal) no período de 6 horas. Valores representativos das médias \pm desvio padrão. * < CTW, $\mathrm{p}<0,05$. O ensaio foi realizado em triplicata.

Figura 8- Expressão do RNAm para pró-colágeno tipo I por fibroblastos de polpa dental humana estimulados pelos materiais H10 (HEMA 10 nM), H100 (HEMA 100 nM), H1000 (HEMA 1000 nM), SB 0,1 (Single Bond 1:10.000), SB 1 (Single Bond 1:1.000), SB 10 (Single Bond 1:100) nos períodos de 6 e 24 horas. Valores representativos das médias \pm desvio padrão. $*<\mathrm{CLE}, \mathrm{p}<0,05$. \# $>$ CLE 6 horas, $p<0,05$. O ensaio foi realizado em triplicata..

Figura 9- Expressão do RNAm para pró-colágeno tipo I por fibroblastos de polpa dental humana estimulados pelos materiais VB (Vitrebond), SB (Single Bond), KM (Ketac Molar), DY (Dycal) no período de 6 horas. Valores representativos das médias \pm desvio padrão. $*<\mathrm{CTW}, \mathrm{p}<0,05$. O ensaio foi realizado em triplicata.

Figura 10- Expressão do RNAm para SDF-1a/CXCL12 por fibroblastos de polpa dental humana estimulados pelos materiais H10 (HEMA 10 nM), H100 (HEMA 100 nM), H1000 (HEMA 1000 nM), SB 0,1 (Single Bond 1:10.000), SB (Single Bond) e KM (Ketac Molar) seguidos por LPS de E. coli no período de 24 horas. Valores representativos das médias \pm desvio padrão. ${ }^{*}>$ CLE LPS, $\mathrm{p}<0,05$. O ensaio foi realizado em triplicata 

Figura 11- Expressão do RNAm para SDF-1a/CXCL12 por fibroblastos de polpa dental humana estimulados pelos materiais H10 (HEMA 10 nM), H100 (HEMA 100 nM), H1000 (HEMA 1000 nM), SB 0,1 (Single Bond 1:10.000), SB 1 (Single Bond 1:1.000), SB 10 (Single Bond 1:100) nos períodos de 6 e 24 horas. Valores representativos das médias \pm desvio padrão. \# > SB 106 horas, $\mathrm{p}<0,05$. O ensaio foi realizado em triplicata.

Figura 12- Expressão do RNAm para SDF-1a/CXCL12 por fibroblastos de polpa dental humana estimulados pelos materiais VB (Vitrebond), SB (Single Bond), KM (Ketac Molar), DY (Dycal) nos períodos de 6 e 24 horas. Valores representativos das médias \pm desvio padrão. \# $>$ DY 6 horas, p<0,05. O ensaio foi realizado em triplicata..

Figura 13- Expressão do RNAm para IL-6 por fibroblastos de polpa dental humana estimulados pelos materiais H10 (HEMA $10 \mathrm{nM}$ ), H100 (HEMA 100 nM), H1000 (HEMA 1000 nM), SB 0,1 (Single Bond 1:10.000), SB 1 (Single Bond 1:1.000), SB 10 (Single Bond 1:100) nos períodos de 6 e 24 horas. Valores representativos das médias \pm desvio padrão. $*<$ CLE, $\mathrm{p}<0,05$. \# $>$ SB 0,1 24 horas, p<0,05. Não foi detectada a expressão do gene IL-6 para os materiais SB 1 e SB 10 no período de 24 horas. $\mathrm{O}$ ensaio foi realizado em triplicata..

Figura 14- Expressão do RNAm para IL-8/CXCL8 por fibroblastos de polpa dental humana estimulados pelos materiais H10 (HEMA 10 nM), H100 (HEMA 100 nM), H1000 (HEMA 1000 nM), SB 0,1 (Single Bond 1:10.000), SB 1 (Single Bond 1:1.000), SB 10 (Single Bond 1:100) nos períodos de 6 e 24 horas. Valores representativos das médias \pm desvio padrão. * < CLE 6 horas, $\mathrm{p}<0,05$. \# $>$ SB 106 horas, $\mathrm{p}<0,05$. O ensaio foi realizado em triplicata.

Figura 15- Expressão do RNAm para IL-8/CXCL8 por fibroblastos de polpa dental humana estimulados pelos materiais VB (Vitrebond), SB (Single Bond), KM (Ketac Molar), DY (Dycal) nos períodos de 6 e 24 horas. Valores representativos das médias \pm desvio padrão. $*<$ CTW 6 horas, $\mathrm{p}<0,05 . \&>\mathrm{CTW}, \mathrm{p}<0,05$. $\mathrm{O}$ ensaio foi realizado em triplicata..

Figura 16- Produção in vitro de SDF-1a/CXCL12 por fibroblastos de polpa dental humana estimulados pelos materiais H10 (HEMA 10 nM), H100 (HEMA 100 nM), H1000 (HEMA 1000 nM), SB 0,1 (Single Bond 1:10.000), SB 1 (Single Bond 1:1.000), SB 10 (Single Bond 1:100) nos períodos de 6 e 24 horas. Valores representativos das médias \pm desvio padrão. ${ }^{*}<\mathrm{CLE}, \mathrm{p}<0,05$. O ensaio foi realizado em duplicata.. 

Figura 17- Produção in vitro de SDF-1a/CXCL12 por fibroblastos de polpa dental humana estimulados pelos materiais VB (Vitrebond), SB (Single Bond), KM (Ketac Molar), DY (Dycal) no período de 24 horas. Valores representativos das médias \pm desvio padrão. $*<$ CTW, $p<0,05$. O ensaio foi realizado em duplicata.

Figura 18- Produção in vitro de IL-6 por fibroblastos de polpa dental humana estimulados pelos materiais VB (Vitrebond), SB (Single Bond), KM (Ketac Molar), DY (Dycal) no período de 6 horas. Valores representativos das médias \pm desvio padrão. \& $>$ CTW, $\mathrm{p}<0,05$. O ensaio foi realizado em duplicata.

Figura 19- Produção in vitro de IL-8/CXCL8 por fibroblastos de polpa dental humana estimulados pelos materiais H10 (HEMA 10 nM), H100 (HEMA 100 nM), H1000 (HEMA 1000 nM), SB 0,1 (Single Bond 1:10.000), SB 1 (Single Bond 1:1.000), SB 10 (Single Bond 1:100) no período de 24 horas. Valores representativos das médias \pm desvio padrão. ${ }^{*}<\mathrm{CLE}, \mathrm{p}<0,05$. \# $>$ CLE, $\mathrm{p}<0,05$. O ensaio foi realizado em duplicata...

Figura 20- Produção in vitro de IL-8/CXCL8 por fibroblastos de polpa dental humana estimulados pelos materiais VB (Vitrebond), SB (Single Bond), KM (Ketac Molar), DY (Dycal) nos períodos de 6 e 24 horas. Valores representativos das médias \pm desvio padrão. $*<\mathrm{CTW}, \mathrm{p}<0,05$. \& $>\mathrm{CTW}, \mathrm{p}<0,05$. O ensaio foi realizado em duplicata..

LISTA DE TABELAS

Tabela 1- Alvos utilizados na RT-PCR e números de catálogos. 59

Tabela 2- gene para RPL13A. 59 



\section{LISTA DE ABREVIATURAS E SIGLAS}

ADA: American Dental Association

bis-GMA: bis-glicidil metacrilato

BSA: bovine serum albumin - soroalbunima bovina

$\mathrm{Ca}(\mathrm{OH})_{2}$ : hidróxido de cálcio

CIV: cimento de ionômero de vidro

CIVMR: cimento de ionômero de vidro modificado por resina

CLE: grupo controle

$\mathrm{CO}_{2}$ : dióxido de carbono

$\mathrm{CoCl}_{2}$ : cloreto de cobalto

CT: cicle threshold - ciclo limiar

CTW: grupo controle transwell

DNA: Deoxyribonucleic Acid - ácido desoxirribonucleico

DMEM: Dulbecco's Modified Eagle's Medium - Meio de Eagle modificado por Dulbecco DY: Dycal

et al.: e colaboradores

ELISA: Enzyme-Linked Immunoabsorbent Assay - Ensaio imunoenzimático

GRO: Growth-related Oncogene - Oncogene relacionado ao crescimento

H: HEMA

H10: HEMA $10 \mathrm{nM}$

H100: HEMA $100 \mathrm{nM}$

H1000: HEMA $1000 \mathrm{nM}$

HEMA: 2-hidroxietil metacrilato

IL: Interleucin - Interleucina

IFN: Interferon

kDa: quilodalton

KM: Ketac Molar 

LAFFIC: Laboratório de Fisiologia e Farmacologia Clínica

LBP: LPS-binding protein - proteína ligadora de LPS

LPS: Lipopolysaccharide - lipopolissacarídeo

LTA: Lipoteichoic acid - ácido lipoteicóico

MDPC-23: células de rato semelhantes a odontoblasto

MIP: Macrophage Inflamatory Protein - Proteína inflamatória para macrófago

MMP: metaloproteinase de matriz

MTA: Mineral Trioxide Aggregate - agregado de trióxido mineral

MTT: 2,5 difenil brometo de tetrazolium

NADPH: nicotinamide adenine dinucleotide phosphate - fostato denucleotídeo adenina nicotinamida

NF-кB: Nuclear Factor kappa B - fator nuclear kappa B

NK: Natural Killer

NED: cloreto de N-(1-naftiletilenodiamino)

$\mathrm{NiCl}_{2}$ : cloreto de níquel

NO: nitric oxide - óxido nítrico

NOS: nitric oxide synthase - óxido nítrico sintase

$\mathrm{PaCl}_{2}$ : cloreto de paládio

PAMP: padrões moleculares associados a patógenos

PBS: Phosphate Buffered Saline - Tampão fosfato salina

$\mathrm{PGE}_{2}$ : prostaglandina $\mathrm{E}_{2}$

RANTES: Regulated on Activation Norma T-cell Expressed and Secreted

ROS: Reactive Oxygen Species - espécies reativas de oxigênio

RNA: Ribonucleic Acid - ácido ribonucleico

RT-PCR: Reverse Transcriptase - Polymerase chain reaction - Transcriptase reversa seguida de reação em cadeia da polimerase 

SB: Single Bond

SB0,1: Single Bond 1:100

SB1: Single Bond 1:1000

SB10: Single Bond 1:10.000

SBF: soro bovino fetal

SDF: Stromal Cell-Derivated Factor - Fator celular derivado de estroma

TA: temperatura ambiente

TEGDMA: dimetacrilato de trietileno glicol

TIMP: Tissue inhibitors of metalloproteinases - inibidor tecidual de metaloproteinases

TLR: Toll-like receptor - receptor do tipo Toll

TGF: Transforming Growth Factor - Fator de crescimento transformador

TNF: Tumor Necrosis Factor - Fator de necrose tumoral

UDMA: uretano dimetacrilato

VB: Vitrebond

VEGF: Vascular Endotelial Growth Factor - Fator de crescimento vascular endotelial 



\section{SUMÁRIO}

1. Introdução e Revisão de Literatura.....................................................................25

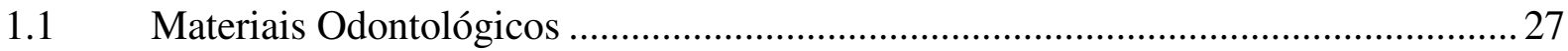

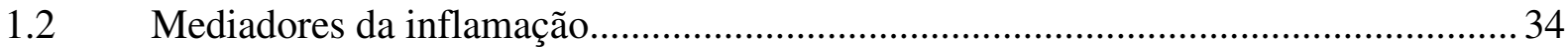

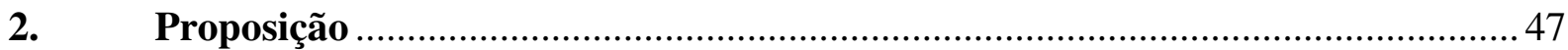

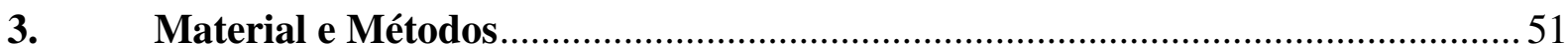

3.1. Coleta do tecido pulpar e estabelecimento de cultura primária................................53

3.2. Estimulação dos fibroblastos pulpares pelos materiais ............................................54

3.3. Estimulação dos fibroblastos pulpares pelos materiais seguidos por LPS de E. coli

3.4. Avaliação da viabilidade celular e do efeito citotóxico dos materiais nos fibroblastos de polpa: Trypan Blue e MTT.

3.5. Avaliação dos níveis de óxido nítrico produzidos por fibroblastos

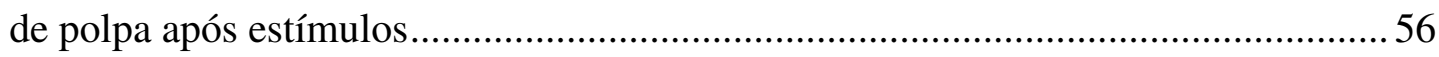

3.6. Avaliação da expressão gênica de pró-colágeno tipo I, MMP-9, SDF-1 $\alpha /$ CXCL12, IL-6 e IL-8/CXCL8 por fibroblastos da polpa.... .56

3.7. Avaliação da produção de SDF-1 $\alpha /$ CXCL12, IL-6 e IL-8/CXCL8 por fibroblastos da polpa 59

3.8. Análise estatística

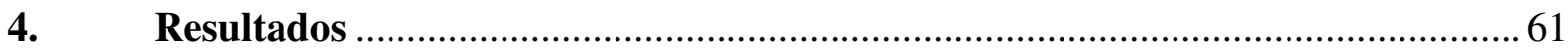

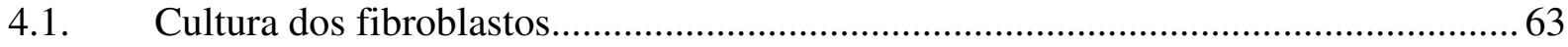

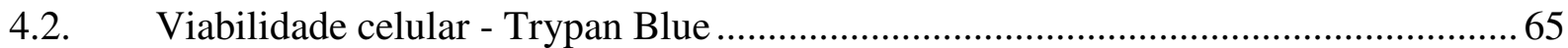

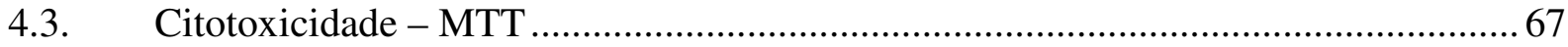

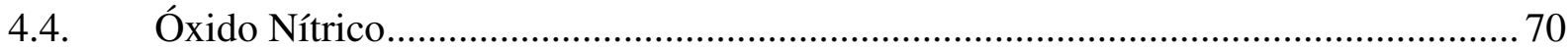

4.5. Expressão gênica do RNAm para pró-colágeno tipo I, MMP-9, SDF-1 $\alpha /$ CXCL12, IL-6 e IL-8/CXCL8 ................................................................. 71

4.6. Detecção da produção de SDF-1 $\alpha /$ CXCL12, IL-6 e IL-8/CXCL8 ............................ 78 



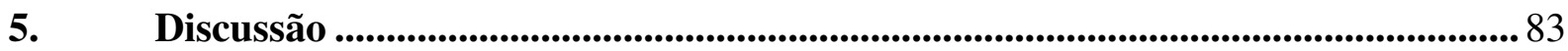

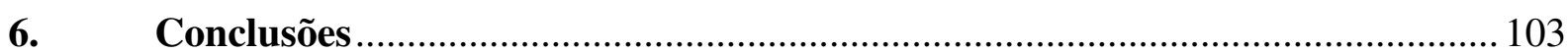

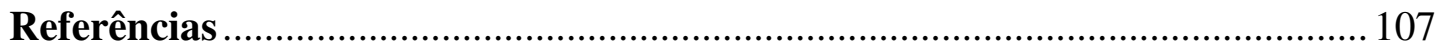

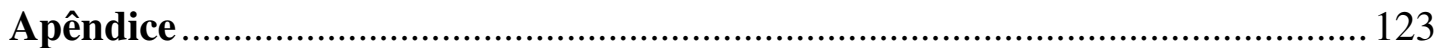

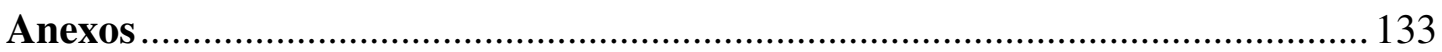



Introduçã e Revisano de Literatura

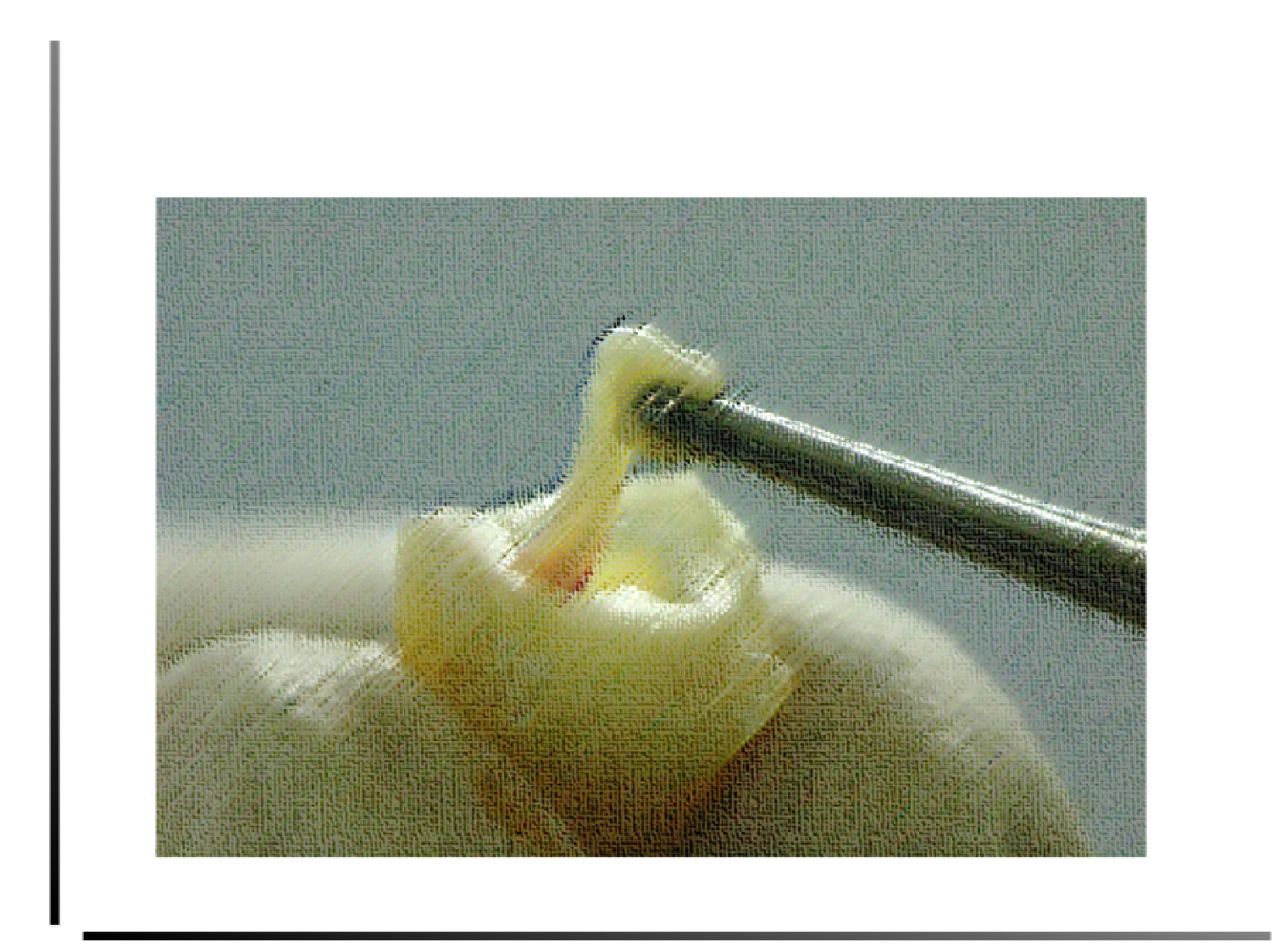





\section{INTRODUÇÃO E REVISÃO DE LITERATURA}

\subsection{Materiais Odontológicos}

O principal objetivo da Odontologia Restauradora é restaurar e manter a saúde do órgão dentário por meio de adequado tratamento restaurador que proteja e restabeleça a função pulpar. A proteção do complexo dentino-pulpar se faz pela aplicação de uma ou mais camadas de materiais específicos entre o material restaurador e o tecido dentário com o intuito de evitar novas agressões ao tecido pulpar, causadas pelos procedimentos operatórios, toxicidade de materiais restauradores, presença de bactérias entre outras. Alguns dos materiais utilizados com essa finalidade são os produtos a base de hidróxido de cálcio, cimentos de ionômero de vidro e adesivos dentinários (MODENA et al., 2009).

É de grande importância o estudo dos materiais de forramento e de proteção do complexo dentino-pulpar em relação à biocompatibilidade, citotoxicidade e capacidade de estimular células da polpa na produção de mediadores da inflamação para que sejam utilizados de maneira correta, sem prejuízo da vitalidade do tecido pulpar.

Os materiais aplicados em terapias restauradoras interagem com os tecidos vizinhos e podem influenciar o organismo como um todo. Embora as propriedades físicas das resinas compostas estejam constantemente sendo melhoradas, estudos in vivo mostram que seu uso como material restaurador está ocasionalmente associado com necrose e irritação da polpa (HANKS et al., 1991; STANLEY et al., 1975; STANLEY et al., 1967) e do periodonto (NASJLETI et al., 1983). A maioria dos componentes dos sistemas adesivos e das resinas compostas como o bis-glicidil metacrilato (BisGMA), uretano dimetacrilato (UDMA), trietileno glicol dimetacrilato (TEG-DMA), canforoquinona, 2-hidroxietil metacrilato (HEMA) e outros possuem citotoxicidade definida quando em contato direto com fibroblastos (HANKS et al., 1991). Os monômeros mais citotóxicos são o Bis-GMA e o UDMA, que causam efeitos irreversíveis no metabolismo celular (HANKS et al., 1991). Estes monômeros quando aplicados em discos de dentina, mesmo com a presença de pressão interna, podem se difundir através dos túbulos dentinários e alcançar a câmara pulpar em concentrações diretamente proporcionais ao peso molecular dos materiais monoméricos (BOUILLAGUET et al., 1996). Os componentes da resina composta podem ser lixiviados durante a polimerização quando o grau de conversão não é totalmente atingido (FERRACANE et al., 
1990; RUEGGEBERG et al., 1988) ou quando a resina é degradada por bactérias, enzimas salivares, como a esterase, ou por hidrólise (FREUND et al., 1990).

Assim como as resinas compostas, os sistemas adesivos são compostos por diversos tipos de monômeros e são usados para aumentar a retenção, reduzir a microinfiltração e diminuir a sensibilidade pós-operatória das restaurações. Estudos in vivo demonstram que a aplicação da resina adesiva diretamente no local de exposição pulpar, ou sobre uma fina camada de dentina (menor que $0,5 \mathrm{~mm}$ ), causa dilatação e congestão dos vasos sanguíneos, inflamação e abscessos pulpares (HEBLING et al., 1999a; HEBLING et al., 1999b). A completa polimerização dos sistemas adesivos pode ser inatingível durante os processos de capeamento pulpar direto. $\mathrm{O}$ oxigênio e a umidade, devido à presença de sangue ou coágulo e exudatos, impedem a completa polimerização dos monômeros dos sistemas adesivos (GERZINA et al., 1996; RUEGGEBERG et al., 1990). Os monômeros não convertidos podem se difundir diretamente para a polpa através dos locais de exposição ou através dos túbulos dentinários e causar efeitos citotóxicos nas células pulpares (HANKS et al., 1994; PASHLEY, 1988). Outros trabalhos defendem o conceito de que a microinfiltração de bactérias ao redor das restaurações em resina composta é responsável pela inflamação pulpar em detrimento dos próprios compósitos (BRÄNNSTRÖM et al., 1972; COX et al., 1987).

Há uma notável diferença nas respostas celulares nas diferentes condições de polimerização (polimerização por 10 ou 40 segundos e não polimerização). Enquanto o sistema adesivo parcialmente polimerizado ou não polimerizado rapidamente induz apoptose em macrófagos, em células indiferenciadas da polpa e em células de rato semelhante à odontoblastos (MDPC-23) a resina adesiva polimerizada induz apoptose apenas em macrófagos. Isso pode ser explicado pela pequena quantidade de elementos tóxicos que são lixiviados das resinas adesivas polimerizadas quando comparado com as não polimerizadas (MANTELLINI et al., 2003).

Um dos problemas encontrados em restaurações adesivas é a degradação da camada híbrida. Essa é formada após a desmineralização superficial da dentina, quando ocorre a penetração da resina adesiva na matriz extracelular da dentina e sua polimerização e a sua degradação afeta a longevidade da restauração pela perda da força adesiva (BRESCHI et al., 2008). As enzimas que participam da degradação da matriz extracelular são as MMPs. A liberação e ativação de proteinases endógenas são responsáveis pela degradação de colágeno em camadas híbridas incompletamente infiltradas (CARRILHO et al., 2007). 
A aplicação de sistemas adesivos convencionais de dois passos (MAZZONI et al., 2006) ou auto-condicionantes (TAY et al., 2006) pode reativar as atividades gelatinolítica/colagenolítica da dentina, o que leva a pensar no papel da MMP-2 e MMP-9 da dentina na degradação de fibrilas colágenas não infiltradas corretamente na camada híbrida, formada tanto na parte coronária quanto na radicular. Essa hipótese foi confirmada por estudos mostrando que o tratamento da dentina condicionada com inibidores de MMP aumentou significantemente a estabilidade adesiva ao longo do tempo (BRESCHI et al., 2010; CARRILHO et al., 2007). A expressão de MMP-2 e MMP-9 também foi verificada em culturas de fatias de dentes após a aplicação de sistema adesivo auto-condicionante. Os resultados mostraram que o sistema adesivo estimulou a produção das MMPs pelo complexo dentino-pulpar após 7 dias, mais precisamente por odontoblastos, sugerindo que eles participam da degradação da camada híbrida (LEHMANN et al., 2009). Em cultura de fibroblastos estimulada por extratos de sistemas adesivos, a expressão de MMP-2 apresentouse aumentada apenas para o grupo em que as células foram incubadas com o meio de cultura que continha os discos de sistema adesivo por 96 horas, sendo que para o sistema adesivo auto-condicionante a expressão foi maior (ORSINI et al., 2011).

Uma alta concentração de HEMA, presente nos primers e nas resinas adesivas disponíveis no mercado, pode promover notáveis efeitos citopáticos em cultura de células pulpares, mesmo após a lavagem do material para diminuir a concentração de agentes ácidos e não ácidos, componentes comuns nas resinas adesivas dentinárias (SOUZA COSTA et al., 1999). Os monômeros não convertidos podem ser liberados dos materiais dentários e agir como radicais livres (MANTELLINI et al., 2003). Os glóbulos resinosos esféricos podem se difundir pelos túbulos dentinários, atingir o espaço pulpar e as células odontoblásticas (TAY et al., 1994). A presença de partículas de resina na polpa parece desencadear uma reação de corpo estranho, caracterizada pela presença de infiltrado inflamatório mononuclear e de células gigantes (GWINNETT et al., 1998).

Outro material de extenso uso na odontologia é o cimento de ionômero de vidro (CIV), surgido em 1971 com Wilson \& Kent, e introduzido no mercado no final da década de 70. Sua popularidade se deve ao fato de possuir importantes propriedades esperadas em um material restaurador como a liberação de flúor, coeficiente de expansão térmica linear próxima à estrutura dentária, biocompatibilidade e adesão (NAVARRO et al., 1998). Apesar das vantagens, os CIVs convencionais possuem limitações como materiais restauradores, 
relacionadas à suscetibilidade à desidratação (CHO et al., 1995) e propriedades físicas pobres como solubilidade e demorada reação de presa (MOUNT, 1994).

Melhorias no campo dos CIVs levaram ao desenvolvimento de uma versão fotopolimerizável, chamada de cimento de ionômero de vidro modificado por resina (CIVMR) (SIDHU et al., 1995). A incorporação de monômeros polimerizáveis e compatíveis com água como HEMA na formulação dos CIVs convencionais resultou no aumento da resistência flexural, resistência à tensão diametral, módulo de elasticidade e resistência ao desgaste (XIE et al., 2000), entretanto podem não ser tão biocompatíveis como os convencionais (STANISLAWSKI et al., 1999). O mecanismo de presa dos CIVMR consiste em duas reações principais: polimerização dos radicais livres dos componentes monoméricos, resultando em uma cadeia polimérica, e a reação ácido-base clássica, que se inicia na mistura do cimento e continua após a ativação por luz resultando numa matriz de polisais (YIU et al., 2004).

A incorporação de HEMA na formulação dos CIVs convencionais aumenta seus efeitos tóxicos (BOUILLAGUET et al., 1996) e como consequência, os CIVMR são considerados mais tóxicos que os convencionais (DE SOUZA COSTA et al., 2003; HUANG et al., 2002; LAN et al., 2003). Embora o grau de conversão do monômero para polímero dos CIVMR não seja determinado (PALMER et al., 1999), muitos estudos demonstram que quantidades mensuráveis são liberadas em soluções de estocagem (BOUILLAGUET et al., 1996; PALMER et al., 1999; STANISLAWSKI et al., 1999). O HEMA residual lixiviado pode facilmente se difundir através dos túbulos dentinários devido à sua hidrofilia e ao baixo peso molecular e atingir as células pulpares (BOUILLAGUET et al., 1996; STANISLAWSKI et al., 1999). A magnitude do dano que pode ser causado pelos monômeros residuais nas células da polpa é inversamente proporcional à camada de dentina remanescente entre a parede pulpar e o tecido pulpar (COSTA et al., 2003). Pode-se esperar que os CIVMR possam desencadear uma reação inflamatória quando aplicados diretamente em contato com o tecido conjuntivo (SOUZA et al., 2006).

Embora o CIVMR seja capaz de tomar presa sem ser ativado pela luz (HSE et al., 1999), são encontrados altos níveis de HEMA liberados quando a presa desses cimentos é apenas química (PALMER et al., 1999). Quando foi avaliada a porcentagem de HEMA liberada em diferentes CIVMR, observou-se que o Vitrebond (CIVMR para forramento) desprendeu maior porcentagem desse monômero que o Vitremer (CIVMR restaurador) após 
imersão em água destilada, mesmo sendo fotopolimerizado de acordo com as instruções do fabricante (PALMER et al., 1999). Outros componentes tóxicos dos CIVMR, como fluoreto, alumínio, prata, silício, estrôncio, zinco e silicato, também podem ser liberados durante a reação de presa ou na solubilização do cimento, com o tempo, em um meio ambiente úmido (KAWAI et al., 2002). Entretanto, Stanislawski et al. (1999) demonstraram que a concentração de íons liberados pelos CIVMR não é alta o suficiente para causar efeitos citotóxicos e que o $\mathrm{Zn}^{2+}$ foi o único componente encontrado em concentração alta o suficiente para induzir citotoxicidade (STANISLAWSKI et al., 1999).

As partículas inorgânicas são os maiores constituintes de materiais como as resinas compostas, compômeros e vários tipos de CIVs. Como as restaurações estão expostas ao desgaste na cavidade oral, essas partículas inorgânicas podem se soltar do material e induzir efeitos tóxicos nos tecidos vizinhos ou células. Células epiteliais de brônquios foram expostas às partículas inorgânicas BaAlSi e BaAlFSi e as produções de IL-6 e IL-8 foram avaliadas. Ambas as partículas aumentaram a produção de IL-8, mas não foi observada mudança na produção de IL-6 (ANSTEINSSON et al., 2009).

Os produtos à base de hidróxido de cálcio são amplamente utilizados, graças à sua comprovada propriedade antibactericida e sua capacidade de estimular a formação de dentina esclerosada, reparadora, e proteger a polpa contra estímulos térmicos (MODENA et al., 2009). A primeira formulação à base de hidróxido de cálcio foi introduzida na odontologia por Hermann (1920), que apresentava, segundo o autor, capacidade de induzir a polpa a formar barreira mineralizada, vedando a superfície exposta. Desde então, o hidróxido de cálcio é utilizado em um grande número de procedimentos como capeamento pulpar direto e indireto, apicificação, tratamento de reabsorção radicular, perfuração radicular iatrogênica, fratura dentária, reimplante dentário e como medicamento intracanal (FARHAD et al., 2005).

Esse material odontológico é, certamente, um dos mais estudados e, devido ao seu efeito direto ou indireto no processo de reparo da polpa exposta, é classicamente utilizado como controle positivo (padrão ouro) nos testes de compatibilidade biológica de materiais com a mesma finalidade. Seu potencial biológico e terapêutico fazem dele um material de escolha primária para todos os procedimentos conservadores da polpa (PEREIRA, 2004).

O cálcio PA, a suspensão ou o cimento de hidróxido de cálcio são recomendados para o tratamento de exposições pulpares e possui propriedades benéficas como a indução da 
mineralização, baixa toxicidade e alto $\mathrm{pH}$, responsável pela inibição do crescimento bacteriano (CAVALCANTI et al., 2005). Muitos trabalhos mostram reparo pulpar e formação de barreira mineralizada quando o tecido pulpar exposto é submetido ao capeamento direto com diferentes formulações de hidróxido de cálcio. Na prática clínica, a presença de barreira mineralizada após o capeamento pode ser considerada uma vantagem, pois proporciona proteção natural contra a infiltração de bactérias e produtos químicos. Entretanto, o valor da barreira mineralizada que protege a polpa tem sido questionado porque pode haver a formação de túneis na barreira mineralizada após o capeamento direto, permitindo a penetração de bactérias no interior do tecido pulpar (GOLDBERG et al., 1984). Stanley \& Pameijer afirmaram que estes túneis são uma consequência do grau de trauma da polpa e do número de vasos sanguíneos lesados durante a exposição mecânica e não do hidróxido de cálcio (STANLEY et al., 1997). Os defeitos na barreira mineralizada, quando presentes, representam inclusões celulares geralmente situadas entre a necrose por coagulação e a zona calcificada (PEREIRA et al., 2000). A presença da barreira mineralizada deve ser reconhecida não apenas como uma barreira física contra agressões, mas também como um sinal de recuperação biológica, representada pela atividade odontoblástica (STANLEY et al., 1997).

O mecanismo de reparo pulpar utilizando hidróxido de cálcio como capeador pulpar direto ainda não é bem compreendido. Entretanto, seu alto $\mathrm{pH}$ alcalino pode solubilizar e liberar algumas proteínas e fatores de crescimento da dentina. Estes eventos podem ser responsáveis pelo reparo pulpar e formação de barreira mineralizada (HEBLING et al., 1999a). Em consequência ao seu elevado pH, quando em contato direto com a polpa, produz uma camada de necrose por coagulação (HOLLAND, 1971). Essa camada cauterizada, em certa extensão, atua de forma semelhante à membrana basal existente entre os ameloblastos e os odontoblastos primários em diferenciação, no momento da formação do esmalte e da dentina (TJÄDERHANE, 2002).

Estudos clássicos em nível microscópico demonstram que o hidróxido de cálcio, ao produzir a necrose superficial da polpa, transforma-se em carbonato de cálcio. Os grânulos de carbonato de cálcio atuam, em um primeiro momento, como núcleos de calcificação distrófica, a margem e no interior da densa deposição de fibras reticulares, imediatamente abaixo da zona de demarcação (HOLLAND, 1971), a partir da qual as células odontoblastóides se diferenciam e se organizam para formar a barreira mineralizada (PEREIRA, 2004). Em princípio, a cauterização produzida pelo hidróxido de cálcio, ao invés 
de atuar como um obstáculo parece ser fundamental para o processo de reparo de polpas expostas (PEREIRA, 2004).

Sugere-se que o aumento do $\mathrm{pH}$ como resultado da presença de íons hidroxila livres pode iniciar ou favorecer a mineralização (TRONSTAD et al., 1981), entretanto outros compostos altamente alcalinos como hidróxido de bário e fosfato de cálcio falharam nesse processo (MITCHELL et al., 1958). O pH alcalino pode neutralizar o ácido lático secretado pelos osteoclastos podendo ajudar na prevenção de possível destruição do tecido mineralizado e o hidróxido de cálcio pode atuar como um tampão local contra as reações ácidas produzidas pelo processo inflamatório (HEITHERSAY, 1975). Tem sido sugerido que os íons cálcio podem reduzir a permeabilidade de novos capilares, portanto, menos fluido intercelular é produzido, o que aumenta a concentração de íons cálcio no local da mineralização (HEITHERSAY, 1975).

Em contrapartida a todas essas características vantajosas, o hidróxido de cálcio é solúvel em água e ácido e possui propriedades físicas deficientes (STANLEY et al., 1997). Outra teoria seria de que através de microinfiltrações, contaminantes como bactérias e seus produtos tóxicos ganham acesso ao tecido pulpar através dos espaços marginais (STANLEY et al., 1997). Portanto, a presença de produtos bacterianos, por meio das microinfiltrações, seria responsável pela inflamação pulpar e necrose e não o hidróxido de cálcio (STANLEY et al., 1997).

A inflamação é uma reação local dos tecidos a qualquer tipo de agressão e ocorre como uma resposta inespecífica caracterizada por uma série de alterações, as quais tendem a limitar os efeitos da agressão. Ou seja, é um conjunto de sinais e sintomas que agem no organismo com o objetivo de inibir ou diminuir os efeitos de agressões causadas por diversos fatores (MONTENEGRO et al., 2008). Esta resposta padrão é comum a vários tipos de tecidos e é mediada por diversas substâncias, mediadores da inflamação, produzidas pelas células danificadas e células do sistema imunitário que se encontram eventualmente nas proximidades da lesão. 


\subsection{MEDiAdORES DA INFLAMAÇÃo}

Embora a polpa e a dentina possuam diferentes estruturas e composição, reagem ao estímulo como uma unidade (D’SOUZA, 2002), denominada complexo dentino-pulpar, por existirem em íntima relação embriológica e funcional formam um complexo indissociável (OKIJI, 2002; PEREIRA, 2004). Quando ocorre exposição da dentina devido a trauma, atrição ou cárie são observadas profundas reações pulpares por meio de mudanças nos fibroblastos, nervos, vasos sanguíneos, odontoblastos, leucócitos e no sistema imunológico (D’SOUZA, 2002). Além da dentina, a polpa interage com outros tecidos como o periodonto e o sistema nervoso central (GOODIS, 2002).

A polpa dental é um tecido conjuntivo exclusivamente situado no interior da câmara pulpar e dos canais radiculares e, esse por sua vez tem como maior constituinte a matriz extracelular, composta por proteínas fibrilares. A polpa, em condições normais, possui populações heterogêneas de células incluindo em maior quantidade fibroblastos. Após o dano, as células mesenquimais indiferenciadas podem contribuir com o reparo pulpar e mineralização. Nervos (axônios e células de Schwann), células vasculares e perivasculares também estão presentes na polpa (GOLDBERG et al., 2004).

São funções da polpa a formação da dentina, inervação e defesa do dente (BHASKAR, 1980). A formação da dentina é a primeira função da polpa. Da papila dental surge uma camada especializada de odontoblastos adjacente e interna à camada interior do órgão do esmalte. $\mathrm{O}$ ectoderma interage com o mesoderma e os odontoblastos iniciam o processo de formação de dentina (SLAVKIN, 1978). A nutrição da dentina é função dos odontoblastos e dos vasos sanguíneos em que há a troca de nutrientes dos capilares para o fluido intersticial pulpar até a dentina através da rede de túbulos criada pelos odontoblastos, onde ficam seus prolongamentos (PASHLEY et al., 2002). A inervação da polpa e da dentina está conectada pelo fluido e seu movimento entre os túbulos dentinários e receptores periféricos, assim como os próprios nervos sensoriais da polpa (BRÄNNSTRÖM et al., 1972). Além da defesa do dente e da polpa ocorrer pela formação de nova dentina em face a agressões, o processo inflamatório também é considerado um estágio inicial do processo reparativo e regenerativo (SIMON et al., 2011).

Um arranjo celular característico pode ser visto na porção periférica da polpa. Uma camada de odontoblastos circunscreve a porção mais externa do tecido pulpar, formando uma 
camada única na qual os corpos celulares estão situados na polpa e os prolongamentos odontoblásticos se estendem para o interior dos túbulos dentinários. Abaixo da camada de odontoblastos, se encontra uma área relativamente livre de células, conhecida como Zona de Weil ou área livre de células, constituída por uma rica rede de fibras nervosas não mielinizadas, capilares sanguíneos e processos de fibroblastos. Subjacente à Zona de Weil encontra-se a zona rica em células constituída basicamente por fibroblastos, células de defesa como macrófagos e linfócitos, células mesenquimais indiferenciadas, fibras colágenas, vasos sanguíneos e fibras nervosas. Essa região é diferenciada pela grande quantidade de fibroblastos em relação à própria polpa (OKIJI, 2002).

Os fibroblastos são as principais e mais numerosas células do tecido conjuntivo, formando uma rede com a matriz extracelular e produzindo uma vasta gama de componentes desta matriz. São também os responsáveis por degradar elementos extracelulares, sendo essenciais para a remodelação do tecido conjuntivo, pela síntese de colágeno tipo I e III e pela síntese e secreção de componentes da matriz extracelular como proteoglicanas e fibronectina. Os fibroblastos são fonte de um grupo de enzimas denominadas metaloproteinases de matriz (colagenase, gelatinase e estromelisina) que degradam macromoléculas da matriz como o colágeno e proteoglicanas (OKIJI, 2002). Fibroblastos gengivais e de ligamento periodontal são capazes de reconhecer antígenos e responder com a produção de mediadores da inflamação (TAMURA et al., 1992; YAMAJI et al., 1995).

A resposta inflamatória da polpa pode ser desencadeada por agressões causadas por procedimentos dentários (calor e materiais restauradores), trauma, atrição, erosão, infecção causada por bactérias oriundas de lesões de cárie, microinfiltração de restaurações ou outras vias de entrada. Nem toda reação pulpar resulta em dano permanente à polpa. A inflamação geralmente é considerada uma reação inflamatória reparativa em que todos os elementos para o reparo estão presentes. Quando a lesão de cárie é eliminada ou se torna paralisada antes que a bactéria atinja a polpa, a inflamação caminha para a resolução e o processo de reparo ocorrerá (TROWBRIDGE, 2002).

A primeira linha de defesa contra os microrganismos é a imunidade natural ou inata, que consiste em mecanismos de defesa celulares e bioquímicos existentes antes que um processo infeccioso se instale. São componentes do sistema imunológico natural as barreiras físicas e químicas como o epitélio e substâncias antibacterianas, células fagocitárias como neutrófilos e macrófagos, células natural killer (NK), proteínas do sangue e citocinas. Quando 
os microrganismos patogênicos evoluem para resistir à imunidade natural, invadindo e replicando-se nas células do hospedeiro, são necessários mecanismos mais poderosos e especializados para a defesa contra esses patógenos. A imunidade adquirida apresenta alto grau de especificidade para distinguir as diferentes moléculas, habilidade para se "lembrar" e responder com mais rapidez a um mesmo microrganismo. Os principais componentes da imunidade adquirida são os linfócitos e seus produtos, os anticorpos (ABBAS et al., 2003)

As substâncias dos microrganismos que estimulam a imunidade inata são conhecidas como padrões moleculares associados a patógenos (PAMPs), e os receptores que se ligam a essas estruturas são chamados de receptores de reconhecimento de padrões (ABBAS et al., 2003). Dentre os receptores de reconhecimento de padrões estão os receptores do tipo Toll (TLRs) que reconhecem como PAMPs componentes da parede de bactérias, como os lipopolissacarídeos (LPS) em bactérias gram-negativas, ácido lipoteicóico (LTA) em bactérias gram-positivas, peptideoglicanas, lipoproteínas, RNA de dupla-hélice encontrado em vírus ou sequências de DNA encontradas em bactérias (ABBAS et al., 2003; COOPER et al., 2010). Quando ocorre a invasão do tecido dental por bactérias cariogênicas, seus componentes são detectados por TLRs-1 a 6 e 9, que são expressos por odontoblastos e fibroblastos pulpares e essa ligação ativa o fator de transcrição $\mathrm{NF}-\kappa \mathrm{B}$, responsável pela regulação da resposta inflamatória molecular (BOTERO et al., 2010; CHANG et al., 2005; FARGES et al., 2009).

A resposta inflamatória representa um balanço entre os mediadores pró-inflamatórios e anti-inflamatórios que neutralizam os efeitos prejudiciais de um irritante enquanto minimiza o dano no tecido. Este conceito é bem ilustrado pela discussão sobre citocinas na inflamação pulpar. Citocinas são proteínas secretadas por células da imunidade inata ou adaptativa em um processo inflamatório que ativa, medeia ou potencializa ações de outras células ou tecidos e também são produzidas em resposta à sinalização do NF-אB (COOPER et al., 2010). Embora a maioria das citocinas presentes no processo inflamatório seja produzida por células inflamatórias como monóctitos/macrófagos, linfócitos e neutrófilos, também podem ser produzidas por células não inflamatórias como os fibroblastos e células endoteliais (BARKHORDAR et al., 2002; COIL et al., 2004; YANG et al., 2003). As citocinas possuem numerosas funções na mediação de atividades pró ou anti-inflamatórias que afetam o processo inflamatório (FOUAD, 2002). Uma ligação entre uma citocina/quimiocina e seu receptor pode induzir a liberação de outras moléculas que iniciam uma cascata de outros estímulos e liberação (TAUB et al., 1994). 
Um grande número de citocinas exibe funções regulatórias que incluem o recrutamento de linfócitos, extravasamento, ativação, diferenciação e produção de anticorpos e são conhecidas como reguladores pró-inflamatórios. Neste grupo estão as interleucinas $1 \alpha$, $1 \beta$ (IL-1 $\alpha$, IL-1 $\beta$ ) e o fator de necrose tumoral $\alpha$ (TNF- $\alpha$ ) (COOPER et al., 2010).

$\mathrm{Na}$ inflamação aguda, macrófagos residentes, em resposta à infecção, podem secretar uma gama variada de mediadores químicos, tais como: IL-1, IL-6, IL-8, IL-12, TNF- $\alpha$, prostaglandina, leucotrienos, radicais de oxigênio e óxido nítrico. $\mathrm{O}$ efeito combinado destes mediadores resultará no desenvolvimento da resposta inflamatória (SIQUEIRA JR, 2000).

Como citocinas anti-inflamatória podem ser citadas IL-4, IL-5, IL-9, IL-10 e IL-13, que agem de várias maneiras para regular a ação de citocinas pró-inflamatórias. Alguns trabalhos incluem a IL-6 como uma citocina imunoregulatória e anti-inflamatória e citam que suas funções anti-inflamatórias são causadas pela supressão de IL-1 e TNF, indução da liberação de glicocorticóide e indução de antagonistas naturais de IL-1 e TNF, além de modulação da reabsorção óssea (BARTON, 1997; KHABBAZ et al., 2000).

IL-6 é conhecida por ser um dos maiores mediadores na regulação da resposta imune frente à inflamação atuando tanto na imunidade inata quanto na adquirida, sendo sintetizada por fagócitos mononucleares, células do endotélio vascular e fibroblastos em resposta a microrganismos e outras citocinas. Na imunidade natural, a IL-6 estimula a síntese de proteínas da fase aguda e a produção de neutrófilos por células-tronco da medula óssea. $\mathrm{Na}$ imunidade adquirida, estimula o crescimento de linfócitos $\mathrm{B}$ que se diferenciam em produtores de anticorpos (ABBAS et al., 2003).

O peptideoglicano da parede celular de Lactobacillus casei mostrou um aumento na produção de IL-6 por células pulpares humanas de uma maneira dose-dependente. Da mesma maneira, LPS de Porphyromonas endodontalis induziu a produção de IL-6 por células de polpa humana que precedeu e foi independente da produção de IL-1. Em polpa dental humana, o nível médio de IL-6 em dentes cariados e sintomáticos foi muito maior do que aquele encontrado em polpa normal (BARKHORDAR et al., 1999). Em tecidos gengivais inflamados, assim como em diferentes células desse tecido como fibroblastos, células endoteliais e macrófagos, foram encontrados elevados níveis de IL-6, diferentemente dos tecidos sadios (TAKAHASHI et al., 1994). 
As quimiocinas são potentes citocinas pró-inflamatórias, dividem familiaridades estruturais e agem mediando o deslocamento de leucócitos e a quimiotaxia de células inflamatórias para o local da inflamação (citocina quimiotática) (FOUAD, 2002). São polipeptídeos entre 8 e $12 \mathrm{kDa}$, classificadas em quatro famílias com base no número e posição dos resíduos de cisteína $\mathrm{N}$-terminal. As duas maiores famílias são as quimiocinas CC (resíduos de cisteína adjacentes) e CXC (resíduos separados por um aminoácido). As quimiocinas dos grupos CC e CXC são produzidas por leucócitos, células endoteliais, células epiteliais e também por fibroblastos. Em algumas destas células, a liberação de quimiocinas é induzida por microrganismos e por outras citocinas como o TNF e IL-1. Essa liberação constitui um importante mecanismo de defesa, pois recruta leucócitos para a região onde ocorre a infecção (ABBAS et al., 2003).

O tipo de infiltrado que caracteriza uma doença específica é controlado em parte por grupos distintos de quimiocinas que atraem especificamente os diferentes tipos celulares de leucócitos (HERLAAR et al., 1999). Quimiocinas da subfamília CXC, como a IL-8, oncogene relacionado ao crescimento (GRO) e fator estroma derivado de célula (SDF), são potentes quimiotáticos e ativadores de neutrófilos (OGURA et al., 2005; SCHALL et al., 1993). Os fibroblastos pulpares também são verdadeiras fontes de quimiocinas como mostrado por alguns estudos (NAGAOKA et al., 1996; OGURA et al., 2005; YANG et al., 2003).

A IL-8 é produzida por um gama de tipos celulares, incluindo neutrófilos, monócitos, macrófagos, fibroblastos e queratinócitos. A liberação de IL-8 ocorre após a estimulação celular com microrganismos (LPS) e mediadores endógenos como a IL-1. A principal função da IL-8 é induzir a migração de células imunocompetentes e efetoras primárias da inflamação, amplificando o processo inflamatório considerado fator chave da doença inflamatória aguda (GEMMELL et al., 1997). Foi demonstrado que polpas acometidas pela inflamação apresentam maiores quantidade de IL-8 que polpas sadias e que fibroblastos pulpares estimulados por LPS também produzem níveis mais elevados de IL-8 que o grupo controle (SILVA et al., 2009).

A expressão do RNAm e a liberação de IL-8 por fibroblastos de polpa dental humana após estimulação por LPS de Prevotella intermedia foi avaliada. Houve um aumento nos níveis de RNAm 2 horas após o início do estímulo por $0,1 \mu \mathrm{g} / \mathrm{mL}$ de lipopolissacarídeo, atingindo o pico máximo em 4 a 8 horas e diminuindo em 48 horas, retornando aos valores iniciais não estimulados em 60 horas. A produção de IL-8 começou a aumentar após 8 horas 
de estimulação por $10 \mu \mathrm{g} / \mathrm{mL}$ de LPS, demonstrando certo atraso em relação à expressão gênica (NAGAOKA et al., 1996).

A liberação de prostaglandina (PG) $\mathrm{E}_{2}$, IL-6 e IL-8 por células em cultura de tecido epitelial oral expostas a cloreto de níquel $\left(\mathrm{NiCl}_{2}\right)$, cloreto de cobalto $\left(\mathrm{CoCl}_{2}\right)$, cloreto de paládio $\left(\mathrm{PaCl}_{2}\right)$ e dimetacrilato de trietileno glicol (TEGDMA), por um período de 24 horas, foi quantificada em um trabalho de Schmalz et al. (2000). Os resultados mostraram que houve aumento de $\mathrm{PGE}_{2}$ após exposição do tecido ao $\mathrm{NiCl}_{2}$ e $\mathrm{CoCl}_{2}$ associado à significante redução na viabilidade celular, mas os níveis de IL-6 e IL-8 não foram aumentados nessas condições experimentais. A expressão de ambas as citocinas foi induzida pelo $\mathrm{PaCl}_{2}$ em condições não tóxicas (SCHMALZ et al., 2000).

Os mesmos autores avaliaram a síntese de IL-6 in vitro em cultura de fibroblastos e queratinócitos estimuladas por metais puros como zinco, níquel, cobre, paládio e cobalto. Foram observados elevados níveis de IL-6 nas culturas expostas a esses metais, sugerindo que os íons metálicos estão envolvidos na atividade pró-inflamatória em níveis tóxicos baixos ou inexistentes (SCHMALZ et al., 1998).

SDF-1 $\alpha /$ CXCL12 é uma quimiocina altamente expressa em condições basais, sendo considerada constitutiva e tem sido frequentemente relacionada à manutenção da homeostasia tecidual. Sua função quimiotática é exercida, além de neutrófilos, sobre linfócitos e monócitos e possui a capacidade de recrutar células-tronco CD34+ (KARIN, 2010). A importância do SDF-1 $\alpha$ no recrutamento de células-tronco e progenitoras foi estabelecida e mostrou que a sua expressão em tecidos afetados por agressões está correlacionada com o recrutamento de células-tronco adultas e reparo no tecido (JIANG et al., 2008). Entretanto, durante o processo inflamatório a expressão de SDF-1 $\alpha /$ CXCL12 pode-se apresentar diminuída (FEDYK et al., 2001; HOSOKAWA et al., 2005). Em polpas dentais acometidas pela inflamação, alguns estudos relataram aumento da expressão dessa quimiocina e de seu receptor (JIANG et al., 2008; JIANG et al., 2008). Discreto aumento foi observado na produção de CXCL12 em polpa dental humana estimulada por Enterococcus faecalis inativado por calor (SIPERT et al., 2010). Embora haja divergência na produção de SDF-1 $\alpha$ em tecidos inflamados, a literatura relata que os fibroblastos são também fontes dessa quimiocina (FEDYK et al., 2001).

Em trabalho do nosso grupo de pesquisa, quando fibroblastos gengivais e de ligamento periodontal foram estimulados por LPS de Porphyromonas gingivalis por períodos de 1, 6 e 
24 horas, a produção basal de SDF-1 $\alpha$ foi diminuída no período de 24 horas e com o aumento da concentração de LPS. Para a produção de IL-6, na primeira hora, os níveis basais foram baixos e não afetados pelas concentrações de LPS. Diferentemente, nos períodos subsequentes, houve um aumento da produção de IL-6 com o aumento da concentração de LPS para os fibroblastos ligamentares. Para os fibroblastos gengivais, a produção foi maior em 6 e 24 horas, porém sem diferenças entre as concentrações do estímulo (MORANDINI et al., 2010).

As células do sistema imunológico, como linfócitos T e B, neutrófilos e macrófagos infiltram o tecido pulpar durante a progressão da lesão de cárie (IZUMI et al., 1995). Entretanto, quando essas células são atraídas para o tecido em sua defesa, podem causar danos significativos para o local da inflamação devido à liberação de enzimas proteolíticas que degradam a matriz extracelular, além de liberar quantidades significativas de espécies reativas de oxigênio (ROS) e de enzimas como as metaloproteinases (MMPs), resultando em dano no tecido (COOPER et al., 2010).

Os microrganismos em lesões de cárie têm sido estudados e observa-se a presença de bastonetes Gram-positivos em 92\% dos dentes, cocos Gram-positivos em 32\%, cocos Gramnegativos em 11,6\% e bastonetes Gram-negativos em 5\% (DAHLÉN et al., 2004). Os odontoblastos são as primeiras células a serem encontradas pelos patógenos orais e são representados na dentina cariada essencialmente por bactérias Gram-positivas (LOVE et al., 2002). Com o progresso da infecção para a interface dentina-polpa, ocorre uma mudança na microflora caracterizada pela diminuição de bactérias aeróbias Gram-positivas e um aumento das anaeróbias Gram-negativas. As últimas, portanto, entram rapidamente em contato com os fibroblastos presentes na região subodontoblástica (STAQUET et al., 2008) e desempenham importante papel no desenvolvimento de sintomatologia por meio da indução da produção de citocinas pró-inflamatórias (KOGA et al., 1985). O lipopolissacarídeo é uma molécula formada por polissacarídeos e fosfolipídeos, sendo componente da membrana externa de bactérias Gram-negativas e capaz de exibir intensa imunoestimulação e atividade inflamatória (RIETSCHEL et al., 1996).

A estrutura do lipopolissacarídeo é formada por um componente anfipático lípide A, que se situa na superfície externa da membrana celular de bactérias e se encontra ligado de maneira covalente a uma região polissacarídea. Essa região polissacarídea é dividida em cadeia lateral (antígeno O) e região do núcleo, responsáveis pelas interações externas. O 
principal indutor de respostas imunológicas é o lípide A. A maior parte do conhecimento que se tem da estrutura da molécula de LPS é concentrada no antígeno derivado da enterobactéria Escherichia coli (KOGA et al., 1985).

A resposta dos fibroblastos frente a estímulos microbianos tem sido estudada em situações diversas, como fibroblastos pulpares estimulados por lipopolissarídeos (LPS) (COIL et al., 2004), ácido lipoteicóico (LTA) (TELLES et al., 2003) ou por sobrenadante de bactérias bucais (LETZELTER et al., 1998). O LPS é capaz de causar ativação celular imediata e liberação de citocinas pró-inflamatórias por macrófagos (RIETSCHEL et al., 1996). O efeito do LPS sobre células de polpa humana foi primeiramente descrito por Nakane et al. (1995) mostrando que o LPS de Escherichia coli, Porphyromonas gingivalis, Porphyromonas endodontalis e Fusobacterium nucleatum foi capaz de afetar a produção de DNA destas células, aumentando ou diminuindo-a dependendo da concentração do estímulo (NAKANE et al., 1995). Em fibroblastos de polpa humana, o LPS de E. coli aumentou a produção de IL-6 (COIL et al., 2004). Entretanto, a expressão de RNAm para IL-8 não foi induzida quando células de polpa dental humana em cultura foram estimuladas por LPS de Salmonella abortusequi e por lípide A de E. coli. Isso pode refletir a especificidade de células pulpares por LPS (NAGAOKA et al., 1996).

O caminho pelo qual o LPS é reconhecido foi esclarecido recentemente. Inicialmente o LPS se liga à proteína ligadora de LPS (LBP) solúvel no sangue ou no fluido extracelular. Este complexo é necessário para que o LPS se ligue a CD14, que existe como uma proteína plasmática solúvel, e uma proteína de membrana ligada à glicofosfatidilinisitol. Ocorrida a ligação entre LPS e CD14, a LBP se dissocia e o complexo LPS-CD14 se associa fisicamente ao TLR4. Uma proteína acessória extracelular chamada MD2 também se liga ao complexo CD14. LPS, CD14 e MD2 são requeridos para que ocorra a sinalização eficiente induzida pelo LPS (ABBAS et al., 2003). O complexo CD14, derivado de fibroblastos de polpa dental em cultura e de citocinas imunoregulatórias, regula a expressão de RNAm de IL-6 quando estas células são expostas a LPS de Prevotella intermedia (TOKUDA et al., 2001). Como visto anteriormente, receptores do tipo toll, TLRs-1 a 6 e 9, são expressos por odontoblastos e fibroblastos pulpares (BOTERO et al., 2010; CHANG et al., 2005; FARGES et al., 2009).

O colágeno é o maior componente orgânico do tecido pulpar, embora a polpa pareça conter menores concentrações de colágeno quando comparada a outros tecidos conjuntivos. Das moléculas de colágeno que existem na polpa, os tipos I e III representam a maior parte do 
tecido conjuntivo (LECHNER et al., 1981). O tipo I é o tipo predominante e pode contribuir para o estabelecimento da arquitetura da polpa. É encontrado na forma de fibrilas estriadas distribuídas em número e densidade variados ao longo do tecido conjuntivo da polpa (OKIJI, 2002).

A produção de colágeno por fibroblastos é alterada em consequência a estímulos microbianos e aumentada nos processos de reparo (OKIJI, 2002; TROWBRIDGE, 2002). Em fibroblastos de polpa foi demonstrada a influência das citocinas TGF- $\beta 1$ e TGF- $\beta 2$ no aumento da síntese de colágeno. Por isso, fibroblastos de tecidos acometidos pela inflamação depositam colágeno em maior quantidade que em condições normais (BARKHORDAR et al., 2002). Entretanto, outro estudo mostra que na presença de altas concentrações de TGF- $\beta$ há uma diminuição da expressão de RNAm para colágeno tipo I por fibroblastos de gengiva (FRAGIADAKI et al., 2011). A presença de IL-1 $\beta$ também aumentou a produção de colágeno por fibroblastos de polpa e de gengiva em humanos (BARKHORDAR et al., 2002). Portanto, a síntese de colágeno é um evento de grande importância para o reparo do tecido conjuntivo (CHAN et al., 2005).

A inflamação da polpa dental é caracterizada por mudanças no fluxo sanguíneo (OLGART et al., 1991), na função das células imunocompetentes (BERGENHOLTZ et al., 1991) e na atividade neuronal (NÄRHI et al., 1983). Muitos mediadores, incluindo a histamina, prostaglandinas e neuropeptídios, estão envolvidos em um ou mais desses processos (STERIN-BORDA et al., 2007), enquanto todos os passos podem envolver o óxido nítrico (NO) (NATHAN, 1992).

O óxido nítrico tem recebido muita atenção desde a descoberta de suas funções no final dos anos 80. Apesar da alta reatividade e meia-vida curta variando entre 3 a 60 segundos (KIECHELE et al., 1993), rapidamente é destruído pelo oxigênio (ARCHER, 1993), sendo que sua oxidação produz nitrito e nitrato (KIECHELE et al., 1993). É um gás solúvel e foi identificado primeiramente pela sua ação no relaxamento muscular, causando vasodilatação. Esse efeito foi demonstrado ser verdadeiro também na polpa. A síntese de NO se realiza por ação de uma enzima, a óxido nítrico sintase (NOS) a partir da oxidação do aminoácido Larginina, que produz NO e L-citrulina, sendo necessária a presença de dois co-fatores, o oxigênio e o fosfato denucleotídeo adenina nicotinamida (NADPH) (FOUAD, 2002). O NO é uma molécula mensageira intracelular (BREDT et al., 1990) com importantes funções cardiovascular, neurológica e imune (NATHAN, 1992). 
De acordo com o local, a quantidade produzida e os alvos no ambiente, o NO pode produzir diferentes efeitos. Pequena quantidade de NO produzida pelo endotélio vascular regula o relaxamento muscular e protege contra a adesão de leucócitos e plaquetas na parede do vaso sanguíneo. Essa propriedade pode ser considerada protetora e anti-inflamatória. Grande quantidade de NO liberada pelas células em resposta a citocinas pode destruir o tecido hospedeiro e diminuir discretamente a resposta celular (FOUAD, 2002). O NO possui um papel nas respostas imunes não específicas, atuando como um agente tóxico em infecções (CARMIGNANI et al., 2000). É possível confirmar que um dos primeiros atuantes em potencial da resposta inflamatória é o NO (CLANCY et al., 1995). Além disso, outros investigadores (BERGGREEN et al., 1999; OLGART et al., 1996) relataram que o NO possui um importante papel na regulação da circulação sanguínea da polpa, descrevendo o seu grande envolvimento na regulação da homeostase vascular dental.

Três isoformas distintas de óxido nítrico sintase (NOS) foram descobertas: endotelial (eNOS), neuronal (nNOS), e induzida (iNOS) (NATHAN, 1992). A nNOS e eNOS estão localizadas nas fibras nervosas (LOHINAI et al., 1997) e nas células endoteliais da polpa dental humana, respectivamente (FELACO et al., 2000). A eNOS e a nNOS são isoformas constitutivas que podem rapidamente sintetizar pequenas quantidades de NO (CARMIGNANI et al., 2000). A iNOS está envolvida principalmente nos processos inflamatórios e produz grandes quantidades de NO.

Estudos sugerem que as três isoformas da NOS podem ser expressas em polpa dental (FELACO et al., 2000; LAW et al., 1999). De acordo com os trabalhos de Silva et al. (2008) NOS está presente em uma pequena quantidade em polpas sadias, aumentado em processos patológicos (SILVA et al., 2008). Entretanto, a eNOS está presente em tecido pulpar sadio, em células endoteliais, fibroblastos e odontoblastos, enquanto que a iNOS nunca é expressa em condições normais, é induzida apenas em processos patológicos (DI NARDO DI MAIO et al., 2004). O NO formado pela eNOS possui papel anti-inflamatório na polpa sadia e durante os períodos iniciais da inflamação em polpa hiperêmica (NATHAN, 1992). O progresso da inflamação na polpa dental está acompanhado por um aumento na atividade da NOS, na maior parte atribuída à iNOS de leucócitos (DI NARDO DI MAIO et al., 2004).

Umas das maneiras de analisar a presença de atividade da NOS é por meio da presença de NADPH-diaforase (NADPH-d), um marcador comum para as três isoformas da NOS, portanto, pode ser um indicador indireto da produção de NO (STOYANOVA et al., 2005). 
Fibroblastos de polpa dental humana e células epiteliais possuem marcação para NADPH-d (DA SILVA et al., 2008), assim como há um aumento na densidade desse marcador em tecidos pulpares inflamados (FELACO et al., 2000).

Metaloproteinases de matriz coletivamente denominadas matrixinas, formam uma família multigênica dentro da classe de metaloproteases com atividade endopeptidásica que medeiam a degradação de praticamente todas as moléculas da matriz extracelular, incluindo colágeno nativo e desnaturado (BIRKEDAL-HANSEN, 1993; VISSE et al., 2003). Até o momento, 24 diferentes MMPs foram clonadas, das quais 23 foram encontradas em humanos (VISSE et al., 2003). MMPs contribuem para a remodelação tecidual tanto normal como patológica. As funções fisiológicas das MMPs incluem migração celular, remodelação tecidual, crescimento, cicatrização, angiogênese, formação do esmalte, apresentação e processamento de antígeno (HANNAS et al., 2007). As MMPs estão associadas com a remodelação da matriz orgânica da dentina (SULKALA et al., 2002). Alguns autores afirmam que, geralmente, as MMPs não são expressas em tecidos sadios, mas são encontradas em processos de reparo ou remodelação óssea, em todos os tecidos inflamados e em todos os tipos celulares em cultura (PARKS et al., 2004).

As MMPs são divididas em 6 grupos: colagenases, gelatinases ou tipo IV colagenase, estromelisinas, matrilisinas, metaloproteinases tipo de membrana e outras (HANNAS et al., 2007). Dentre as gelatinases estão a MMP-2 e a MMP-9 e a ativação dessas duas metaloproteinases possui um papel crucial na quebra do colágeno da dentina em lesões de cárie (SULKALA et al., 2001).

A degradação do tecido inflamado possui quatro caminhos reconhecidos: o caminho plasminogênio-dependente, o fagocítico, o osteoclástico e o caminho dependente da MMP (BIRKEDAL-HANSEN, 1993). Quando toxinas, como as produzidas por bactérias atingem a dentina, geralmente ocorre inflamação pulpar. Se a lesão de cárie não for removida, este processo inflamatório avança. A pulpite está associada à degradação tecidual. Quando os níveis de MMP e a atividade gelatinolítica em polpas dentais humanas clinicamente inflamadas e saudáveis foram comparados, os dados indicaram que MMP-9 pode ser importante na quebra do tecido pulpar dental humano inflamado. Níveis de MMP-1 e MMP-2 foram significantemente menores em polpas sintomáticas que em clinicamente sadias. Em contrapartida, níveis de MMP-9 em polpas inflamadas foram significantemente maiores que em polpas normais, portanto a expressão da MMP-9 pode ter um papel importante na 
patogênese da inflamação pulpar (GUSMAN et al., 2002; TSAI et al., 2005). A MMP-9 além de estar altamente expressa em tecidos inflamados, foi detectada em células como odontoblastos, fibroblastos, células inflamatórias e células endoteliais (TSAI et al., 2005).

Com o avanço de estudos mais aprofundados sobre a área da saúde, pode-se verificar um aumento no número das descobertas científicas em relação à participação dos diversos mediadores nos eventos relacionados à inflamação, entretanto são raros os trabalhos que investigam os efeitos de materiais colocados em direto contato com o tecido pulpar em relação à produção de citocinas inflamatórias. Cavalcanti et al. (2011) avaliaram a secreção de IL-1 $\beta$ e IL-8 por neutrófilos humanos usando diferentes materiais de capeamento pulpar direto: hidróxido de cálcio $\left[\mathrm{Ca}(\mathrm{OH})_{2}\right]$, sistema adesivo (Single Bond) e agredado de trióxido mineral (MTA). A produção de IL-8 foi maior em todos os grupos avaliados em relação ao grupo controle, sendo que no grupo do sistema adesivo foi maior que no do MTA. A produção de IL-1 $\beta$ foi maior apenas no grupo do MTA (CAVALCANTI et al., 2011).

A compatibilidade biológica dos materiais dentários é de grande importância para evitar ou limitar irritação ou degeneração dos tecidos adjacentes ao local onde são aplicados, especialmente porque os materiais de proteção do complexo dentino-pulpar estão em íntimo contato com a dentina vital e até mesmo com o tecido pulpar e seus efeitos sobre os fibroblastos pulpares são uma grande preocupação.

A polpa dental é objeto de estudo não apenas pelas implicações clínicas dos seus processos patológicos, mas também devido a fatores específicos como sua localização interna a um tecido duro com paredes inflexíveis, seu suprimento vascular particular e dinâmica celular, que juntos levam a um interesse crescente pela resposta que a polpa exerce a agressões (GOODIS, 2002). Essas agressões podem ser causadas por metabólitos provenientes de microrganismos envolvidos com infecções pulpares tanto agudas quanto sintomáticas, como o LPS de E. coli, ou por componentes que são liberados de materiais odontológicos. As quimiocinas exercem papel fundamental nos processos inflamatórios, recrutando células de defesa, sendo de grande interesse o estudo da liberação dessas proteínas por células da polpa, em especial por fibroblastos (BARKHORDAR et al., 2002; MARTINEZ et al., 2004; RAVANTI et al., 1999).

Uma vez que a inflamação não ocorre por igual em todos os tecidos conjuntivos do organismo, há necessidade de conhecer as reações que determinados materiais provocam quando colocados em íntimo contato com o tecido pulpar. Pela predominância numérica dos 
fibroblastos no tecido pulpar e pelos recentes relatos acerca da capacidade destas células reagirem a estímulos agressivos por meio da liberação de quimiocinas, metaloproteinases e óxido nítrico, que desempenham importante função na resposta inflamatória, eles se tornaram os alvos desta pesquisa. 


$$
E
$$





\section{PROPOSIÇÃO}

\section{OBJETIVO GERAL}

Investigar a influência de materiais utilizados na prática clínica odontológica na resposta inflamatória de fibroblastos cultivados de polpa dental humana proveniente de dentes permanentes em relação à expressão e produção de mediadores da inflamação.

\section{OBJETIVOS ESPECÍFICOS}

Avaliar a citotoxicidade dos materiais HEMA, Single Bond (3M ESPE), Vitrebond (3M ESPE), Ketac Molar (3M ESPE), Dycal (Dentsply) e lipopolissacarídeo de Escherichia coli e a viabilidade celular de fibroblastos de polpa dental humana quando estimulados pelos materiais citados.

$\checkmark$ Avaliar os níveis de nitrito produzidos por fibroblastos de polpa dental humana estimulados pelos materiais supracitados e também estimulados pelos materiais seguidos por lipopolissacarídeo de Escherichia coli.

Avaliar a expressão gênica de pró-colágeno tipo I, MMP-9, SDF-1 $\alpha /$ CXCL12, IL-6 e IL-8/CXCL8 por fibroblastos de polpa dental humana estimulados pelos materiais supracitados e também estimulados pelos materiais seguidos por lipopolissacarídeo de Escherichia coli.

Avaliar a produção de SDF-1 $\alpha /$ CXCL12, IL-6 e IL-8/CXCL8 por fibroblastos de polpa dental humana estimulados pelos materiais supracitados. 



$$
E
$$





\section{MATERIAL E MÉTODOS}

\subsection{COLETA DO TECIDO PULPAR E ESTABELECIMENTO DE CULTURA PRIMÁRIA}

Terceiros molares hígidos extraídos de um mesmo paciente livre de doenças sistêmicas foram obtidos no Laboratório de Fisiologia e Farmacologia Clínica (LAFFIC) da Faculdade de Odontologia de Bauru da Universidade de São Paulo. Os dentes foram doados pelo paciente em formulário específico devidamente aprovado pelo Comitê de Ética em Pesquisa da FOB/USP (Processo $n^{\circ}$ 137/2007). O armazenamento foi feito em Dulbecco's Modified Eagle's Medium (DMEM) (Gibco, Invitrogen Life Technologies, Carlsbad, CA, EUA) até o laboratório de cultura de células para extração do tecido pulpar. Após a remoção de todo o tecido aderido ao redor do dente (gengiva e ligamento periodontal), um sulco transversal com ponta diamantada esférica (\#1014 KG Sorensen), sob refrigeração, foi realizado na região da junção amelocementária, em toda a circunferência do dente. Com um alveolótomo cirúrgico, o dente foi fraturado e aberto, removendo-se o tecido pulpar. A polpa foi picotada, o tecido imerso em meio de cultura DMEM (Gibco, Invitrogen Life Techologies, Carlsbad, CA, EUA) suplementado com 10\% de Soro Bovino Fetal (SBF) e centrifugado a $200 \mathrm{~g}$, por 5 minutos em temperatura ambiente (TA). Os fragmentos foram ressuspensos, colocados em garrafas para cultura de $25 \mathrm{~cm}^{2}$ com DMEM, $10 \%$ de SBF, $100 \mu \mathrm{g} / \mathrm{mL}$ de penicilina, $100 \mu \mathrm{g} / \mathrm{mL}$ de estreptomicina e $0,5 \mathrm{mg}$ de anfotericina B (Gibco, Invitrogen Life Techologies, Carlsbad, CA, EUA) e mantidos a $37{ }^{\circ} \mathrm{C}$ com $5 \%$ de $\mathrm{CO}_{2}$ em incubadora (IncuSafe, Sanyo Electric, Co., Ltda, Japan).

As culturas foram mantidas até os fibroblastos alcançarem confluência com troca do meio DMEM e 10\% de SBF a cada dois ou três dias. Após confluência, os fibroblastos foram repicados e a sua utilização ocorreu a partir da $4^{\mathrm{a}}$ passagem. O protocolo seguido para a cultura dos fibroblastos foi o mesmo utilizado em trabalhos anteriores realizados no Laboratório de Farmacologia do Departamento de Ciências Biológicas da Faculdade de Odontologia de Bauru, Universidade de São Paulo (MORANDINI et al., 2010; MORANDINI et al., 2011; SIPERT, 2007; SIPERT et al., 2010) 


\subsection{ESTIMULAÇÃO DOS FIBROBLASTOS PULPARES PELOS MATERIAIS}

Os materiais utilizados para o estímulo dos fibroblastos de polpa de dente permanente humano foram: HEMA - H, Single Bond - SB (3M ESPE), Vitrebond - VB (3M ESPE), Ketac Molar - KM (3M ESPE) e Dycal - DY (Dentsply).

$\mathrm{VB}, \mathrm{SB}, \mathrm{KM}$ e DY, foram preparados sob condições estéreis e em discos medindo 5 mm x 2 mm obtidos a partir de um molde pré-fabricado (MANTELLINI et al., 2003). Os espécimes VB e SB foram fotoativados com o aparelho Astralis 3 (Ivoclar Vivadent) calibrado a $700 \mathrm{~mW} / \mathrm{cm}^{2}$ pelo tempo recomendado pelo fabricante e no caso do KM e DY foram deixados tomar presa também de acordo com as instruções do fabricante. A superfície dos materiais VB e SB foram protegidas com uma tira de poliéster para evitar a formação da camada inibida pelo oxigênio. Os espécimes foram colocados sobre uma membrana permeável (Maxicell 24W 0,4 $\mu \mathrm{m}$ ) para evitar o contato direto com as células (MANTELLINI et al., 2003). O grupo controle para esses materiais foi denominado CTW, constituído por meio de cultura, células sem estímulo e a membrana permeável.

O monômero HEMA foi utilizado nas concentrações 10 (H10), 100 (H100), 1000 (H1000) nM e colocados diretamente no meio de cultura (MANTELLINI et al., 2006), assim como o Single Bond não polimerizado, utilizado nas concentrações 1:10.000 (SB 0,1), 1:1000 (SB 1) e 1:100 (SB 10) em DMEM 10\%. O grupo controle para esses materiais foi denominado CLE, constituído por meio de cultura e células sem estímulo.

As células foram distribuídas em placas de 24 poços numa quantidade de $5 \times 10^{4}$ células por poço e deixadas até atingir sub-confluência em meio de cultura DMEM, com trocas do meio de cultura a cada dois ou três dias, mantidas em incubadora a $37{ }^{\circ} \mathrm{C}$ com $5 \%$ de $\mathrm{CO}_{2}$.

Após 6 e 24 horas, como padronizado em pesquisas anteriores realizadas em nosso laboratório (MORANDINI et al., 2010; MORANDINI et al., 2011; SIPERT, 2007; SIPERT et al., 2010), o sobrenadante e as células foram coletados e submetidos às análises descritas posteriormente. 


\subsection{EstimUlaÇÃO DOS FIBROBLASTOS PULPARES PELOS MATERIAIS SEGUIDOS POR LPS DE E. COLI}

As células foram distribuídas em placas de 24 poços numa quantidade de $5 \times 10^{4}$ células por poço e deixadas até atingir confluência com trocas do meio de cultura a cada dois ou três dias. Após 24 horas de estimulação dos fibroblastos pulpares pelos materiais H10; H100; H1000; SB 0,1; SB 1; SB 10,VB; SB; KM e DY estes foram removidos e o meio de cultura $(1 \mathrm{~mL}$ ) contendo $10 \mu \mathrm{g} / \mathrm{mL}$ de LPS de E. coli (número de catálogo L4391, Sigma Chemical Co., ST. Luis, Mo.) foi adicionado aos poços, conforme protocolo descrito na literatura (TELLES et al., 2003). Após 24 horas, o sobrenadante e as células foram coletados e submetidos às análises descritas posteriormente.

\subsection{AvaliaçÃo da Viabilidade CelulaR E do EFEITO Citotóxico dos MATERIAis NOS FIBROBLASTOS DE POLPA: TRYPAN BLUE E MTT}

Após a estimulação dos fibroblastos de polpa dentária humana por um período de 6 e 24 horas, os materiais foram removidos e as células lavadas com soro fisiológico, retiradas da placa pela adição de tripsina $(100 \mu \mathrm{L})$ e neutralizadas pelo meio de cultura DMEM a $10 \%$ $(300 \mu \mathrm{L})$. As células foram submetidas à centrifugação a $1200 \mathrm{~g}$ por 10 minutos em TA e ressuspendidas em $200 \mu \mathrm{L}$ de meio de cultura DMEM 10\% de SBF. A viabilidade celular foi determinada pela contagem das células em um hemocitômetro, usando o corante Trypan Blue.

O ensaio de redução do MTT (2,5 difenil brometo de tetrazolium) foi usado para avaliar a citotoxicidade dos materiais aos fibroblastos pulpares e também do LPS de E. coli após o período de estimulação de 6 e 24 horas. Os materiais foram removidos, os sobrenadantes armazenados em freezer a $-80^{\circ} \mathrm{C}$ e a solução de MTT (Invitrogen), adicionada às células. A solução foi utilizada na concentração de $5 \mathrm{mg} / \mathrm{mL}$ em PBS estéril, na proporção de $40 \mu \mathrm{L}$ da solução de MTT e $360 \mu \mathrm{L}$ de meio de cultura, por poço, onde permaneceu incubada por um período de 4 horas em incubadora a $37^{\circ} \mathrm{C}$ em $5 \%$ de $\mathrm{CO}_{2}$, protegida de luz. Decorrido esse período, a solução foi retirada dos poços e descartada. Álcool isopropílico $(200 \mu \mathrm{L})$ foi adicionado aos poços e a placa deixada em mesa agitadora em TA por 30 minutos. Após essa etapa, a placa foi levada ao leitor de microplaca (FLUOstar OPTIMA, BMG LABTECH, Ortenberg, Germany) com comprimento de onda ajustado para $570 \mathrm{~nm}$, no qual a leitura de absorbância foi realizada (MOSMANN, 1983). 


\subsection{AvaliaçÃo dos Níveis de ÓXIdo Nítrico PRODUZIdOS POR FIBROBLASTOS DE POLPA APós ESTÍMULOS}

A partir do sobrenadante das células estimuladas com os diferentes materiais e com LPS de E. coli, os níveis de NO foram dosados pelo ensaio colorimétrico do nitrato/nitrito (análise de Griess), adicionando-se a $50 \mu \mathrm{L}$ de cada amostra, $50 \mu \mathrm{L}$ de solução de sulfanilamida $1 \%$ em solução de ácido fosfórico 5\%. Transcorridos 10 minutos, foram adicionados $50 \mu \mathrm{L}$ de solução NED [cloreto de N-(1-naftiletilenodiamino)] 0,1\% em água. Após incubação por 10 minutos em TA e protegido da luz, realizou-se a leitura em comprimento de onda entre 520 e $550 \mathrm{~nm}$ usando um leitor de microplaca e a concentração foi calculada usando as curvas padrões do nitrato (SCHULZ et al., 1999).

\subsection{Avaliação da eXPREssão gênica de PRó-ColÁgeno TIPo I, MMP-9, SDF- $1 \alpha /$ CXCL12, IL-6 E IL-8/CXCL8 POR FIBROBLASTOS DA POLPA}

Após a estimulação dos fibroblastos pulpares pelos materiais H10; H100; H1000; SB 0,1; SB 1; SB 10; VB; SB; KM; DY; e pelos materiais seguidos por LPS de E.coli, a expressão de RNAm para pró-colágeno tipo I, MMP-9, SDF-1 $\alpha / C X C L 12$, IL-6 e IL8/CXCL8 foi avaliada por transcrição reversa (RT) seguida de reação em cadeia da polimerase (PCR) quantitativa.

\subsubsection{Extração de RNA total}

O RNA total foi extraído a partir de $5 \times 10^{4}$ células utilizando o reagente TRIzol (Life Technologies). A extração de RNA total foi feita pelo método guanidino-isotiocianato-fenolclorofórmio conforme descrito na literatura e reproduzido pelo grupo de pesquisa do Laboratório de Farmacologia, do Departamento de Ciências Biológicas (MORANDINI et al., 2010; SANTOS et al., 2003; SANTOS et al., 2002). Os fibroblastos foram homogeneizados, armazenados em tubos de microcentrífuga e congelados a $-80^{\circ} \mathrm{C}$. Após o descongelamento, as amostras foram incubadas por 5 minutos em TA e adicionado um volume de $30 \%$ de clorofórmio. Os tubos foram vigorosamente agitados e deixados em repouso em TA por 10 minutos, sendo em seguida centrifugados a $13000 \mathrm{~g}$ por 15 minutos a $4^{\circ} \mathrm{C}$. A camada superior (fase aquosa) foi recuperada em alíquotas de $300 \mu \mathrm{L}$ e colocada em tubos de microcentrífuga 
contendo $600 \mu \mathrm{L}$ de isopropanol. Os tubos foram agitados vigorosamente e deixados em repouso em TA por 10 minutos. Após centrifugação a $13000 \mathrm{~g}$ por 10 minutos a $4{ }^{\circ} \mathrm{C}$, o sobrenadante foi descartado e adicionado $1 \mathrm{~mL}$ de etanol 75\% [em água com dietil pirocarbonato (DEPC) $0,1 \%$, em seguida os tubos foram agitados vigorosamente. Foi realizada nova centrifugação a $8000 \mathrm{~g}$ por 5 minutos a $4{ }^{\circ} \mathrm{C}$, descartando-se o sobrenadante e repetindo-se outra centrifugação com $500 \mu \mathrm{L}$ de etanol $100 \%$ a $8000 \mathrm{~g}$ por 5 minutos a $4{ }^{\circ} \mathrm{C}$. Para permitir a secagem das amostras, o sobrenadante foi descartado e os tubos deixados abertos em TA. Para ressuspender o RNA total, adicionaram-se $12 \mu \mathrm{L}$ de água tratada com DEPC $0,1 \%$ aos tubos de microcentrífuga.

\subsubsection{QUANTIFICAÇÃO DO RNA TOTAL}

A concentração de RNA total nas amostras foi determinada por leitura em espectrofotômetro, colocando-se $1 \mu \mathrm{L}$ de cada amostra no aparelho Nanodrop® 1000 (Thermo Scientific, Wilmington, EUA). As leituras foram realizadas em comprimento de onda entre 260 e $280 \mathrm{~nm}$ e a concentração das amostras foi fornecida pelo equipamento em $\mathrm{ng} / \mu \mathrm{L}$.

\subsubsection{TRATAMENTO DO RNA TOTAL COM DNASE}

Para evitar a possibilidade de contaminação do RNA total extraído por DNA genômico, procedeu-se o tratamento de todas as amostras com $1 \mu \mathrm{g}$ de RNA total cada com DNAse (gDNAse Wipeout Buffer, Qiagen, Alemanha), durante 2 minutos a $42{ }^{\circ} \mathrm{C}$. Este procedimento foi realizado seguindo-se as orientações do fabricante, conforme documentado em trabalho do grupo de pesquisa do Laboratório de Farmacologia, do Departamento de Ciências Biológicas (SANTOS et al., 2003).

\subsubsection{TRANSCRIÇÃO REVERSA}

Imediatamente após o tratamento com DNAse, a transcrição reversa das amostras de RNA em cDNA foi realizada por meio do kit comercial QuatiTect Reverse Transcription Kit (Qiagen, Hilden, Alemanha) seguindo as instruções do fabricante. Foram adicionados por amostra $1 \mu \mathrm{L}$ da enzima transcriptase reversa, $4 \mu \mathrm{L}$ de tampão Quantscript RT, $1 \mu \mathrm{L}$ de RT 
primer e uma nova incubação foi realizada a $42{ }^{\circ} \mathrm{C}$ por 30 minutos seguida de $95{ }^{\circ} \mathrm{C}$ por 3 minutos, em um volume final de reação de $20 \mu \mathrm{L}$.

\subsubsection{PCR QUANTITATIVO}

A expressão quantitativa do RNAm para pró-colágeno tipo I, MMP-9, SDF1 $\alpha /$ CXCL12, IL-6 e IL-8/CXCL8 foi analisada por meio de reações de PCR quantitativo, utilizando-se o sistema Taqman® (Applied Biosystems, Life Technologies, EUA) em um aparelho ViiA7 (Applied Biosystems, Life Technologies, EUA). Foram utilizados primers e sonda inventoriados, conjugadas ao fluoróforo FAM, disponibilizados pela mesma empresa, listados na tabela 1. Como gene constitutivo foi realizada a amplificação do gene para RPL13A listado na tabela 2 (PALMQVIST et al., 2008).

Foram utilizados $1 \mu \mathrm{L}$ de cDNA, sintetizado a partir do RNAm, de cada amostra, juntamente com reagentes Taqman ${ }^{\circledR}$ Gene Expression Mastermix (Applied Biosystems, Life Technologies, EUA), primers e sondas como determinado pelo fabricante, com um volume final de reação de $5 \mu \mathrm{L}$. A reação de amplificação compreende 2 minutos a $50{ }^{\circ} \mathrm{C}, 10$ minutos a $95{ }^{\circ} \mathrm{C}, 45$ ciclos de 15 segundos a $95^{\circ} \mathrm{C}$ e 1 minuto a $60{ }^{\circ} \mathrm{C}$, conforme recomendado pelo fabricante. Os resultados foram analisados com base no valor de cicle threshold ou ciclo limiar $(\mathrm{Ct})$, sendo este o ponto correspondente ao número de ciclos a partir do qual a amplificação atinge um dado limiar que permite a análise quantitativa da expressão do gene avaliado. As médias dos valores de $\mathrm{Ct}$ de medidas em duplicata foram utilizadas para calcular a expressão do gene alvo, com normalização em relação a um controle interno (RPL13A) e comparados a um controle alvo interno de uma amostra do grupo de células não estimuladas, obtendo-se assim o cálculo do aumento da expressão, utilizando a fórmula $2^{-\Delta \Delta \mathrm{Ct}}$. 
Tabela 1: Alvos utilizados na RT-PCR e números de catálogos.

\begin{tabular}{|c|c|}
\hline Alvos & $\begin{array}{l}\text { Número de catálogo (Applied Biosystems, Life } \\
\text { Technologies, EUA) }\end{array}$ \\
\hline Pró-colágeno tipo I & Hs01028970_m1 \\
\hline MMP9 & Hs00234579_m1 \\
\hline SDF-1 $\alpha /$ CXCL12 & Hs00171022_m1 \\
\hline IL-6 & Hs00985639_m1 \\
\hline IL-8/CXCL8 & Hs00174103_m1 \\
\hline
\end{tabular}

Tabela 2: gene para RPL13A (PALMQVIST et al., 2008).

\begin{tabular}{l|l|l}
\hline Alvo & Primer & Sonda \\
\hline RPL13A & CCGCTCTGGACCGTCTCAA & (VIC) \\
CCTGGTACTTCCAGCCAACCT & TGACGGCATCCCACCGCCCT \\
& & (TAMRA) $-3^{\prime}$ \\
\hline
\end{tabular}

\subsection{Avaliação da PRODUÇÃo DE SDF-1 $\alpha /$ CXCL12, IL-6 E IL-8/CXCL8 POR FIBROBLASTOS DA POLPA}

A produção de SDF-1 $\alpha /$ CXCL12, IL-6 e IL-8/CXCL8 extracelular foram quantificadas usando o método de ensaio imunoenzimático (ELISA - Enzyme-Linked Immunoabsorbent Assay), a partir do sobrenadante coletado após os estímulos pelos materiais H10; H100; H1000; SB 0,1; SB 1; SB 10; VB; SB; KM; DY. Placas de 96 poços foram sensibilizadas com anticorpo primário ou de captura, diluídos em tampão de ligação carbonato/bicarbonato para IL-6 e IL-8/CXCL8 e PBS (phosphate buffered saline - solução salina tamponada por fosfato) para SDF-1 $\alpha /$ CXCL12, de acordo com as instruções do fabricante (R\&D Systems, Minneapollis, EUA). Após o tempo de incubação (15 a 18 horas) 
em TA, as placas foram lavadas com PBS contendo Tween 20 0,05\% e bloqueadas durante 2 horas, em TA, com PBS contendo soroalbumina bovina (PBS BSA) (Sigma-Aldrich) 1\%. As placas foram novamente lavadas com PBS Tween 20 e incubadas com as amostras e com quantidades conhecidas das citocinas recombinantes durante 2 horas em TA (R\&D Systems, Minneapollis, EUA). Após este período, as placas foram lavadas e incubadas com os anticorpos secundários biotinilados por 2 horas também em TA. Após nova lavagem, foi realizada a incubação da enzima estreptavidina (Becton, Dickinson \& Co. - BD - Franklin Lakes, NJ, EUA) diluída em PBS BSA 1\% na proporção de 1:250 por 20 minutos em TA. As placas foram novamente lavadas e a reação foi revelada pela adição de tetrametilbenzidina e peróxido de hidrogênio na proporção de 1:1 (BD) conforme as instruções do fabricante. A reação foi interrompida, após 30 minutos, pela adição de ácido sulfúrico $4 \mathrm{~N}$ e a leitura realizada em espectrofotômetro ajustado para o comprimento de onda de $450 \mathrm{~nm}$ (ELISA microplate reader, Bio-Rad, Hercules, CA, USA).

\subsection{ANÁLISE ESTATÍSTICA}

A análise estatística foi realizada utilizando o programa GraphPad Prism 5.0. As diferenças estatisticamente significantes foram determinadas por meio da análise de variância à 1 critério (ANOVA) seguida do pós teste de Tukey para os materiais independentes do tempo e análise de variância à 2 critérios (ANOVA) seguida do teste de correção de Bonferroni para as comparações entre os materiais e os tempo experimentais. Foi adotado nível de significância de 5\% para a verificação das possíveis diferenças entre os grupos. 

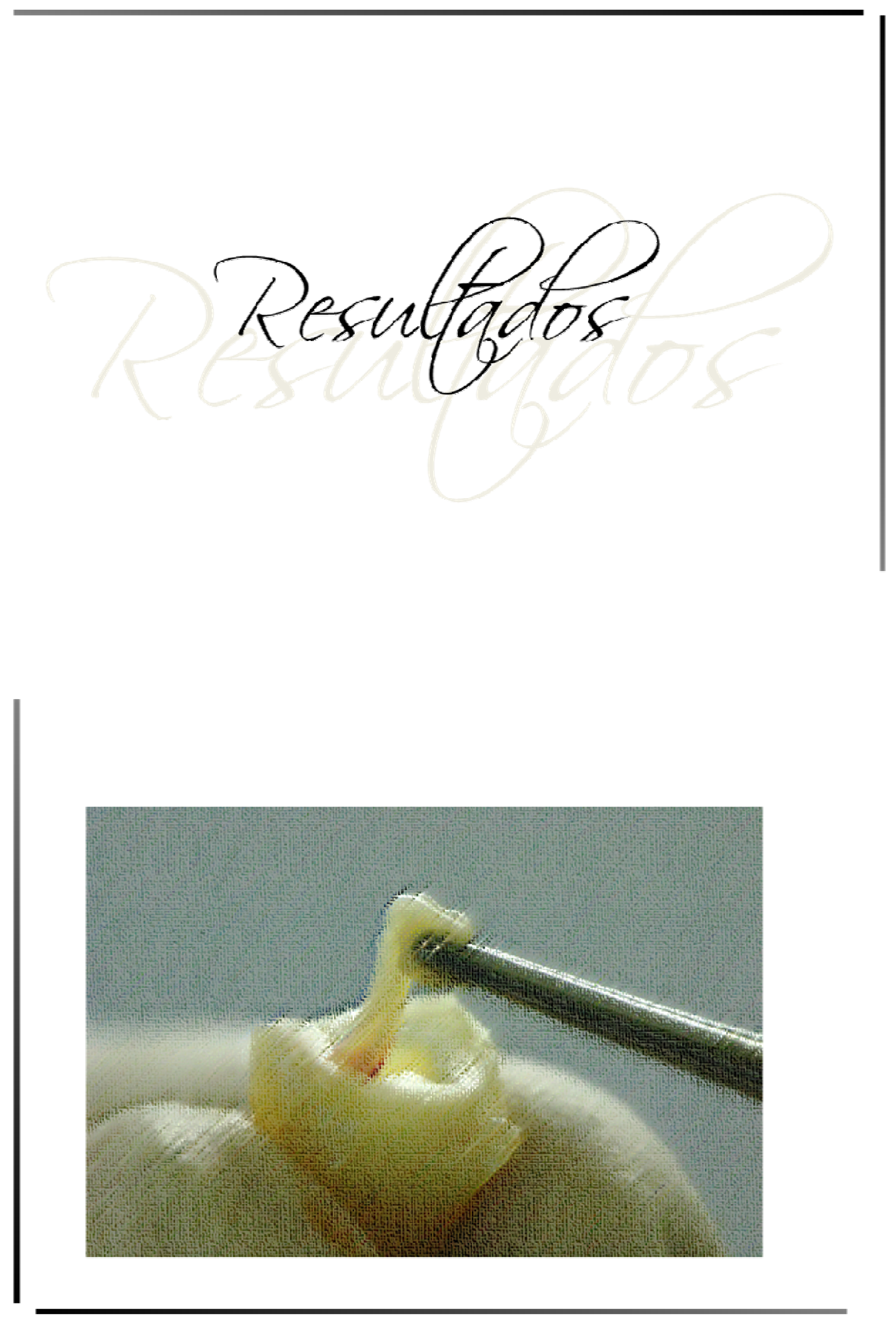



\section{RESULTADOS}

\subsection{Cultura dos Fibroblastos}

A Figura 1 ilustra imagens da cultura de células a partir de tecido pulpar de dente permanente humano observada em microscópio invertido com contraste de fases.
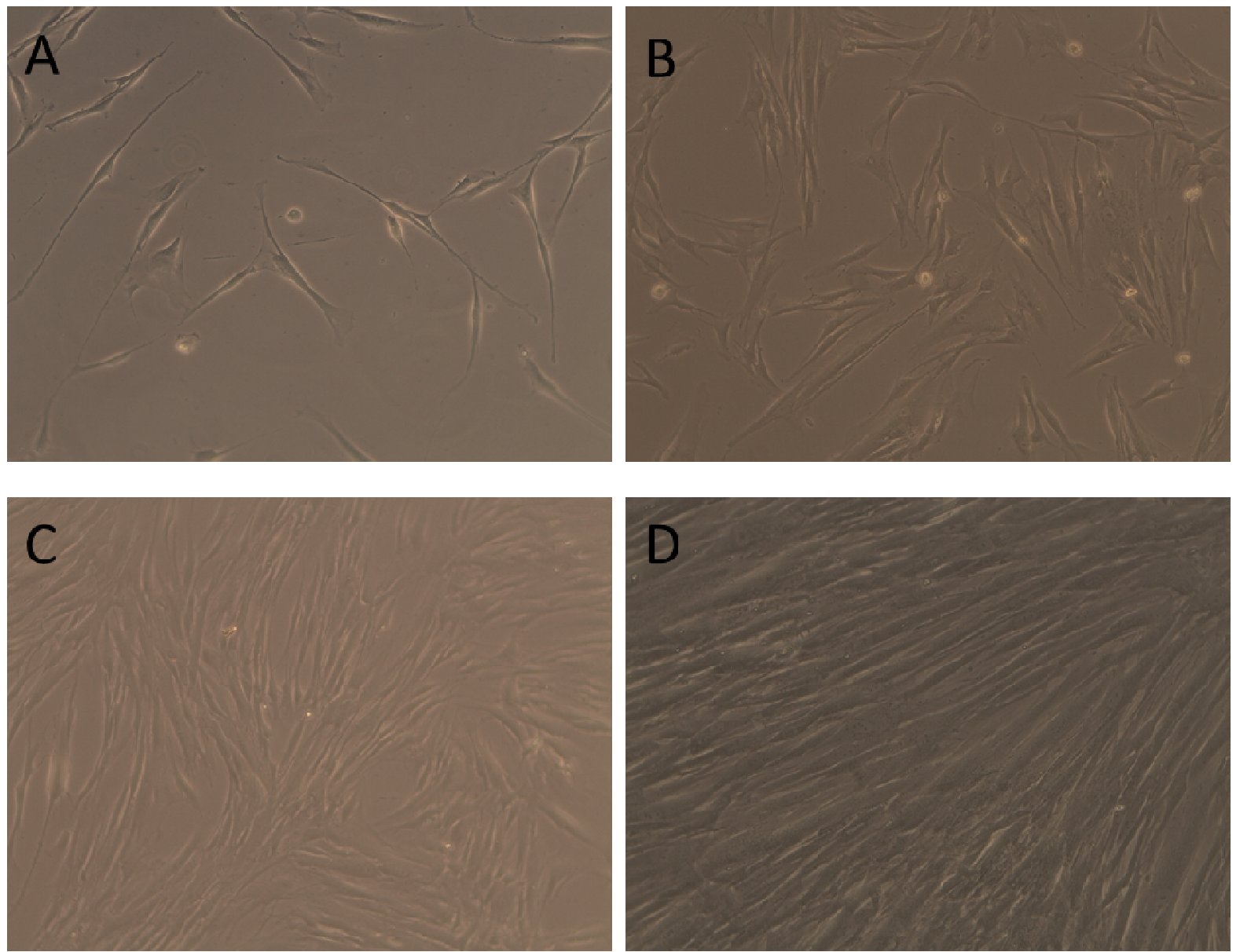

Figura 1- Fibroblastos de polpa dental humana. A cultura primária foi estabelecida por meio de técnica de explant. Sete dias do início da cultura (A), 14 dias (B), 17 dias (C) e 21 dias (D). Visualização em microscópio óptico invertido com contraste de fases com aumento de 10X.

A seguir serão apresentados apenas os resultados em que foram observadas diferenças estatisticamente significativas; os demais resultados estão no apêndice. 



\subsection{ViabilidAdE CELULAR - TRYPAN BLUE}

A viabilidade celular foi avaliada após a estimulação dos fibroblastos de polpa dentária humana pelos materiais por um período de 6 e 24 horas. CLE representa o controle dos materiais H10 (HEMA 10 nM), H100 (HEMA 100 nM), H1000 (HEMA 1000 nM), SB 0,1 (Single Bond 1:10.000), SB 1 (Single Bond 1:1.000), SB 10 (Single Bond 1:100) e CTW representa o controle dos materiais VB (Vitrebond), SB (Single Bond), KM (Ketac Molar), DY (Dycal). Os resultados mostraram que no período de 6 horas, houve uma diminuição estatisticamente significativa $(\mathrm{p}<0,05)$ da porcentagem de células vivas para o material SB 10, a concentração mais alta utilizada do Single Bond quando comparado ao grupo controle não estimulado. Para o período de 24 horas, houve uma diminuição estatisticamente significativa $(\mathrm{p}<0,05)$ da porcentagem de células vivas para os materiais SB 10 e DY, quando comparados com seus respectivos controles, CLE e CTW. Os dados obtidos estão representados nas Figuras 2 e 3. 


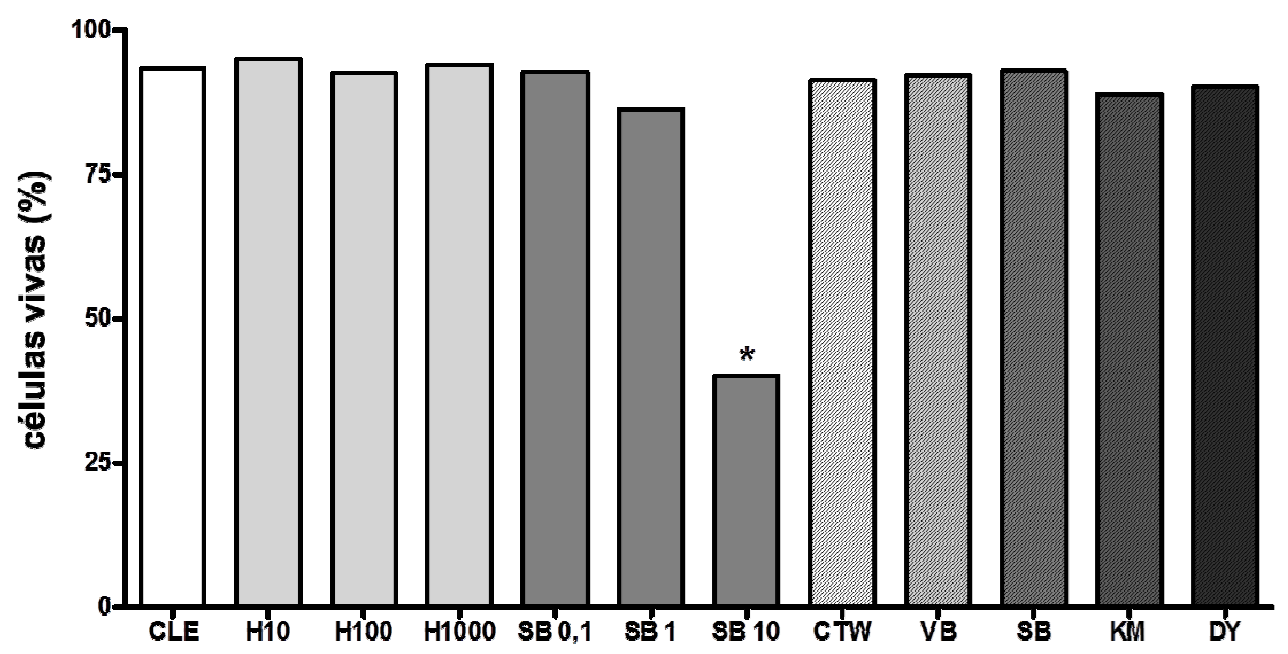

Figura 2- Ensaio de viabilidade celular (Trypan Blue) dos fibroblastos de polpa dental humana quando estimulados pelos materiais H10 (HEMA $10 \mathrm{nM}$ ), H100 (HEMA $100 \mathrm{nM}$ ), H1000 (HEMA $1000 \mathrm{nM}$ ), SB 0,1 (Single Bond 1:10.000), SB 1 (Single Bond 1:1.000), SB 10 (Single Bond 1:100) comparados ao grupo controle CLE e VB (Vitrebond), SB (Single Bond), KM (Ketac Molar), DY (Dycal) comparados ao grupo controle CTW. Valores dados em porcentagem de células vivas no período de 6 horas. ${ }^{*}<\mathrm{CLE}, \mathrm{p}<0,05 ; \mathrm{n}=3$.

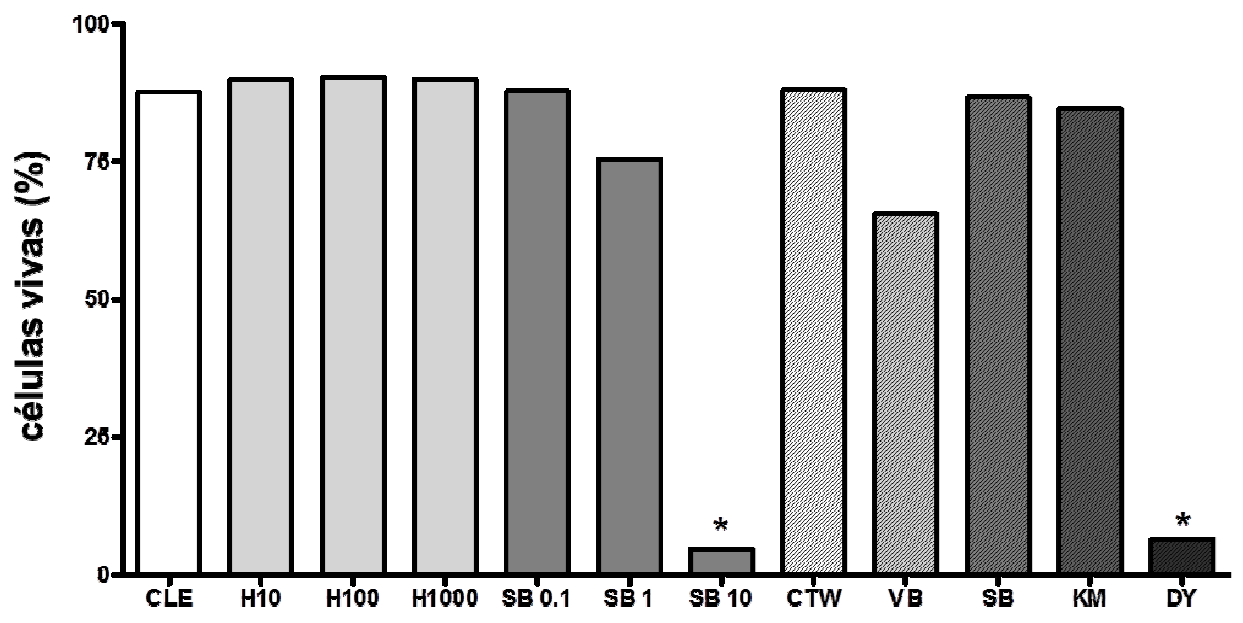

Figura 3- Ensaio de viabilidade celular (Trypan Blue) dos fibroblastos de polpa dental humana quando estimulados pelos materiais H10 (HEMA 10 nM), H100 (HEMA 100 nM), H1000 (HEMA 1000 nM), SB 0,1 (Single Bond 1:10.000), SB 1 (Single Bond 1:1.000), SB 10 (Single Bond 1:100) comparados ao grupo controle CLE e VB (Vitrebond), SB (Single Bond), KM (Ketac Molar), DY (Dycal) comparados ao grupo controle CTW. Valores dados em porcentagem de células vivas no período de 24 horas. $*<$ que os respectivos controles, $\mathrm{p}<0,05 ; \mathrm{n}=3$. 


\subsection{CitotoxicidAde - MTT}

A citotoxicidade dos materiais aos fibroblastos de polpa dental humana foi avaliada pelo ensaio de redução do MTT após o período de estimulação de 6 e 24 horas e dos materiais seguidos por LPS de E. coli após o período de 24 horas. Da mesma maneira, CLE representa o controle dos materiais H10 (HEMA 10 nM), H100 (HEMA 100 nM), H1000 (HEMA 1000 nM), SB 0,1 (Single Bond 1:10.000), SB 1 (Single Bond 1:1.000), SB 10 (Single Bond 1:100) e CTW representa o controle dos materiais VB (Vitrebond), SB (Single Bond), KM (Ketac Molar), DY (Dycal). CLE LPS representa um grupo controle com células estimuladas apenas com o LPS de E. coli. Os resultados mostraram que no período de 6 horas, não houve diferença estatisticamente significativa entre os materiais testados. Para o período de 24 horas estimulados apenas com material, houve uma diminuição estatisticamente significativa $(\mathrm{p}<0,05)$ do valor da densidade óptica para os materiais SB 10 e DY, quando comparados com seus respectivos controles, CLE e CTW. Estimulando os fibroblastos com material seguidos de LPS de E. coli por um período de 24 horas, resultou em diminuição do valor de densidade óptica para os materiais VB, SB 1 e SB 10 em relação ao grupo controle e de SB 1 e SB 10 em relação a SB 0,1. Os dados obtidos estão representados nas Figuras 4, 5 e 6. 


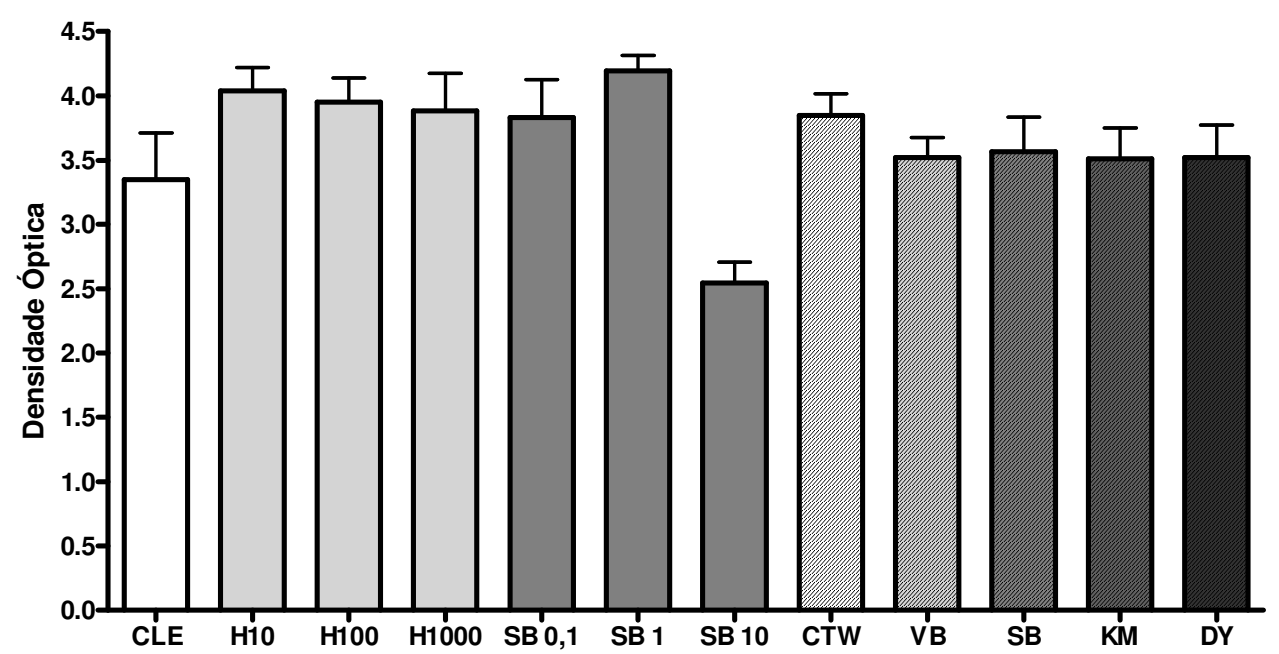

Figura 4- Citotoxicidade (MTT) dos materiais H10 (HEMA 10 nM), H100 (HEMA 100 nM), H1000 (HEMA $1000 \mathrm{nM}$ ), SB 0,1 (Single Bond 1:10.000), SB 1 (Single Bond 1:1.000), SB 10 (Single Bond 1:100) comparados ao grupo controle não estimulado CLE e VB (Vitrebond), SB (Single Bond), KM (Ketac Molar) e DY (Dycal) comparado ao grupo controle CTW, utilizados para estimular fibroblastos de polpa dental humana no período de 6 horas. Valores representativos das médias \pm desvio padrão, $n=3$. Não houve diferença estatisticamente significativa para os grupos estudados.

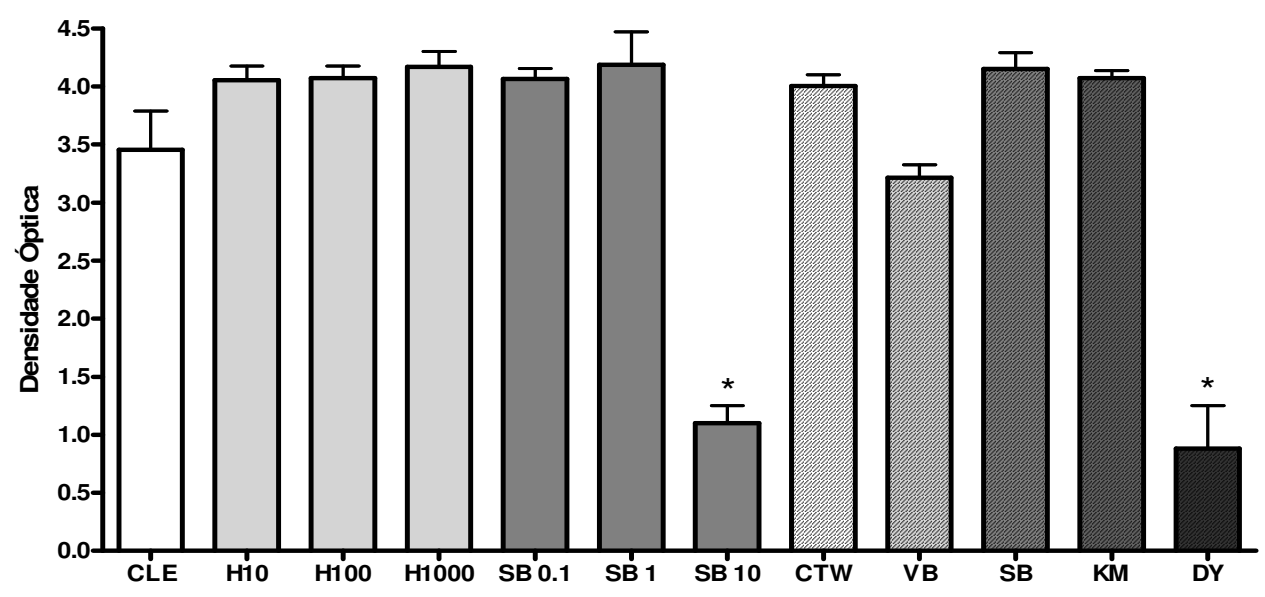

Figura 5- Citotoxicidade (MTT) dos materiais H10 (HEMA 10 nM), H100 (HEMA 100 nM), H1000 (HEMA $1000 \mathrm{nM}$ ), SB 0,1 (Single Bond 1:10.000), SB 1 (Single Bond 1:1.000), SB 10 (Single Bond 1:100) comparados ao grupo controle não estimulado CLE e VB (Vitrebond), SB (Single Bond), KM (Ketac Molar) e DY (Dycal) comparado ao grupo controle CTW, utilizados para estimular fibroblastos de polpa dental humana no período de 24 horas. Valores representativos das médias \pm desvio padrão. $*<$ que os respectivos controles, $\mathrm{p}<0,05 ; \mathrm{n}=3$. 


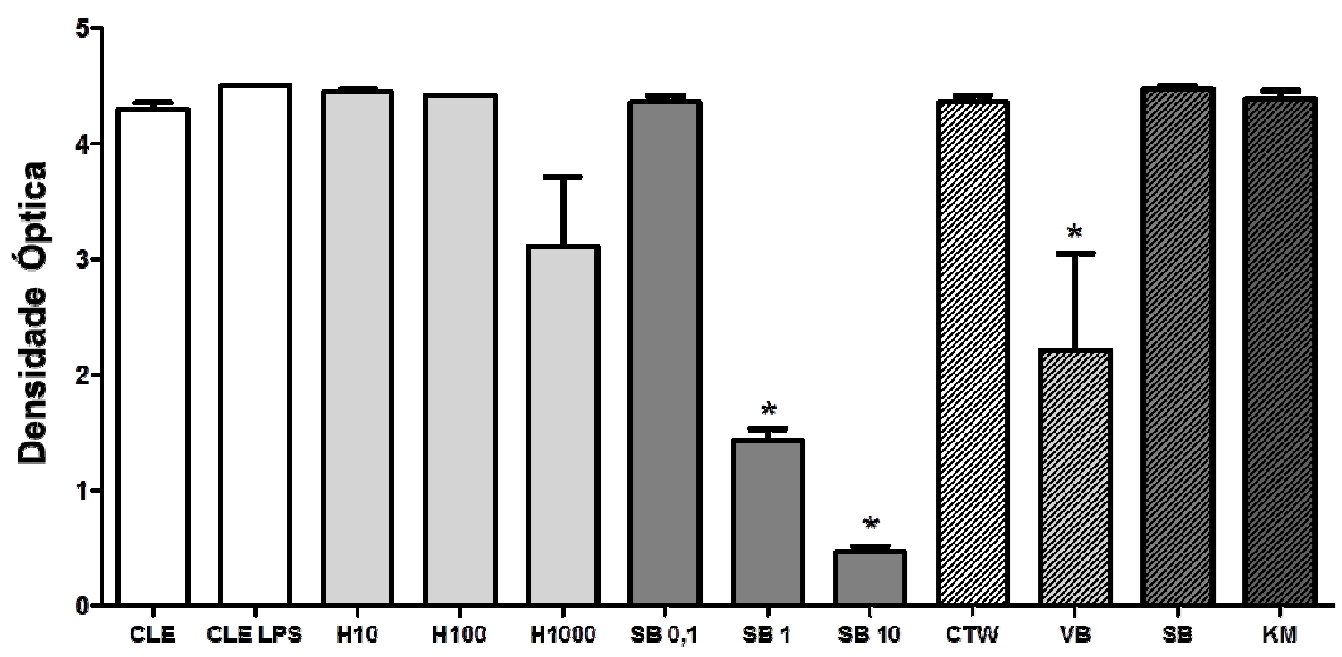

Figura 6- Citotoxicidade (MTT) dos materiais H10 (HEMA 10 nM), H100 (HEMA 100 nM), H1000 (HEMA $1000 \mathrm{nM}$ ), SB 0,1 (Single Bond 1:10.000), SB 1 (Single Bond 1:1.000), SB 10 (Single Bond 1:100), VB (Vitrebond), SB (Single Bond) e KM (Ketac Molar) seguidos por estímulo por LPS de E. coli comparado ao grupo controle CLE, CLE LPS e CTW no período de 24 horas. Valores representativos das médias \pm desvio padrão. $*<$ CLE, CLE LPS e CTW, p<0,05. O ensaio foi realizado em triplicata. 


\section{4 ÓXIDO NÍTRICO}

O ensaio colorimétrico de Griess foi utilizado para dosar a quantidade de nitrato/nitrito produzida a partir do sobrenadante das células estimuladas pelos materiais H10 (HEMA 10 nM), H100 (HEMA 100 nM), H1000 (HEMA 1000 nM), SB 0,1 (Single Bond 1:10.000), SB 1 (Single Bond 1:1.000), SB 10 (Single Bond 1:100) comparados ao grupo controle CLE e VB (Vitrebond), SB (Single Bond), KM (Ketac Molar), DY (Dycal) comparados ao grupo controle CTW. As células também foram estimuladas pelos materiais seguidos por LPS de $E$. coli. Foi verificada diferença estatisticamente significativa $(\mathrm{p}<0,05)$ para KM, em que houve uma diminuição dos níveis de nitrato/nitrito quando comparado ao grupo controle CTW no período de 6 horas. O resultado está representado na Figura 7.

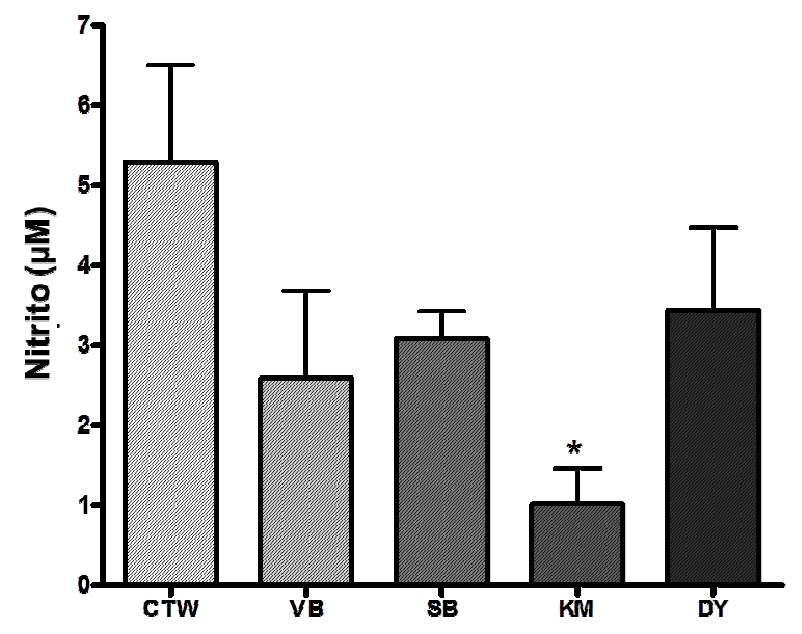

Figura 7- Quantidade de nitrito produzida por fibroblastos de polpa dental humana estimulados pelos materiais VB (Vitrebond), SB (Single Bond), KM (Ketac Molar), DY (Dycal) no período de 6 horas. Valores representativos das médias \pm desvio padrão. $*<\mathrm{CTW}, \mathrm{p}<0,05$. O ensaio foi realizado em triplicata. 


\subsection{EXPRESSÃo GÊNICA DO RNAm PARA PRÓ-COLÁGENO TIPO I, MMP-9, SDF- $1 \alpha /$ CXCL12, IL-6 E IL-8/CXCL8}

O estudo da expressão gênica dos alvos pró-colágeno tipo I, MMP-9, SDF1 $\alpha /$ CXCL12, IL-6 e IL-8/CXCL8 por fibroblastos de polpa dental humana foi realizado por meio de PCR quantitativo precedido de transcrição reversa. As amostras foram estimuladas pelos materiais H10 (HEMA 10 nM), H100 (HEMA 100 nM), H1000 (HEMA 1000 nM), SB 0,1 (Single Bond 1:10.000), SB 1 (Single Bond 1:1.000), SB 10 (Single Bond 1:100) e comparadas ao grupo controle CLE; VB (Vitrebond), SB (Single Bond), KM (Ketac Molar), DY (Dycal) e comparadas ao grupo controle CTW pelo tempo experimental de 6 e 24 horas e com os mesmos materiais seguidos por LPS de E. coli pelo período de 24 horas. CLE LPS representa outro grupo controle de células estimuladas apenas por LPS de E. coli.

Não foi possível observar qualquer sinal de amplificação do gene para MMP-9, sendo assim, pode-se sugerir que nos períodos experimentais avaliados de 6 e 24 horas não foi detectada a expressão gênica da MMP-9.

A amplificação dos genes para pró-colágeno tipo I, SDF-1 $\alpha / C X C L 12$, IL-6 e IL8/CXCL8 foi avaliada e normalizada pelo gene de referência RPL13A. As Figuras 8, 9, 10, $11,12,13,14$ e 15 representam apenas os grupos em que houve diferença estatisticamente significativa $(\mathrm{p}<0,05)$ para os alvos estudados. 


\section{EXPRESSÃo GÊNICA PARA PRÓ-COLÁGENO TIPO I}

De acordo com os resultados, houve uma diminuição estatisticamente significativa $(\mathrm{p}<0,05)$ na expressão do RNAm para pró-colágeno tipo I quando os fibroblastos foram estimulados pelo material SB 10 (Single Bond 1:100), no período de 24 horas e um aumento no CLE em 24 horas quando comparado ao mesmo grupo em 6 horas (Figura 8). Para o período de 6 horas, houve uma diminuição estatisticamente significativa $(p<0,05)$ da expressão desse gene para os materiais SB (Single Bond) e DY (Dycal) quando comparados ao grupo controle CTW (Figura 9).

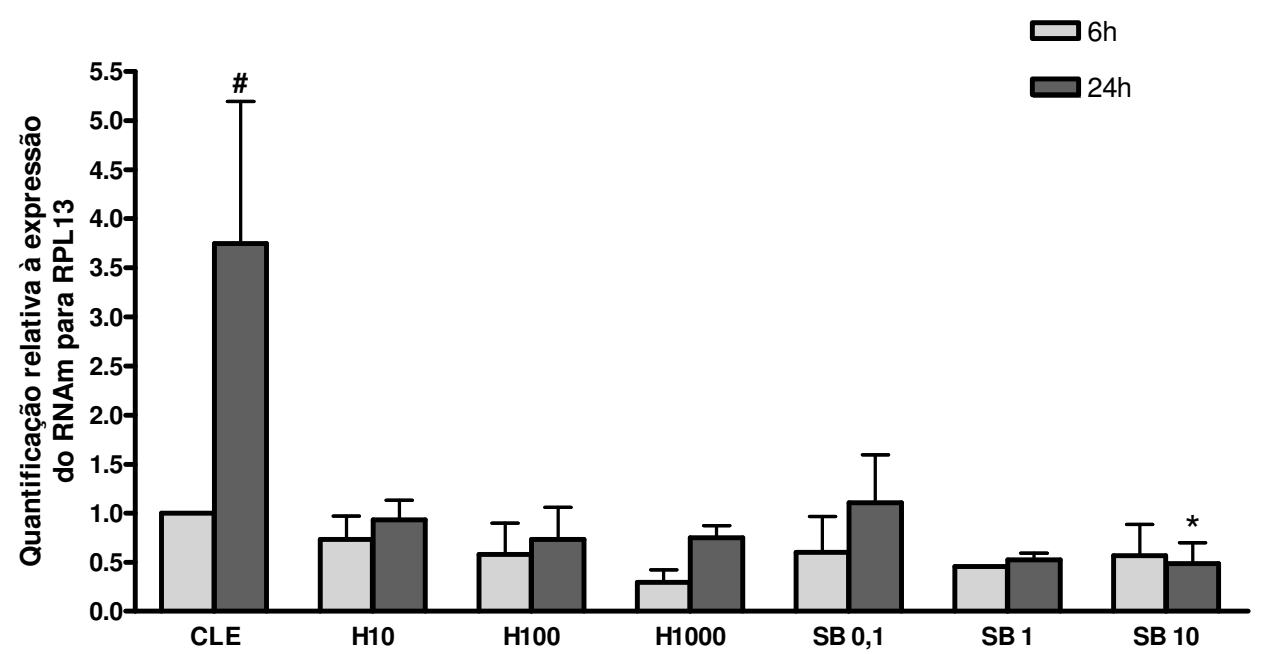

Figura 8- Expressão do RNAm para pró-colágeno tipo I por fibroblastos de polpa dental humana estimulados pelos materiais H10 (HEMA $10 \mathrm{nM}$ ), H100 (HEMA $100 \mathrm{nM}), \mathrm{H} 1000$ (HEMA $1000 \mathrm{nM})$, SB 0,1 (Single Bond 1:10.000), SB 1 (Single Bond 1:1.000), SB 10 (Single Bond 1:100) nos períodos de 6 e 24 horas. Valores representativos das médias \pm desvio padrão. * $<$ CLE, p<0,05. \# $>$ CLE 6 horas, p<0,05. O ensaio foi realizado em triplicata.

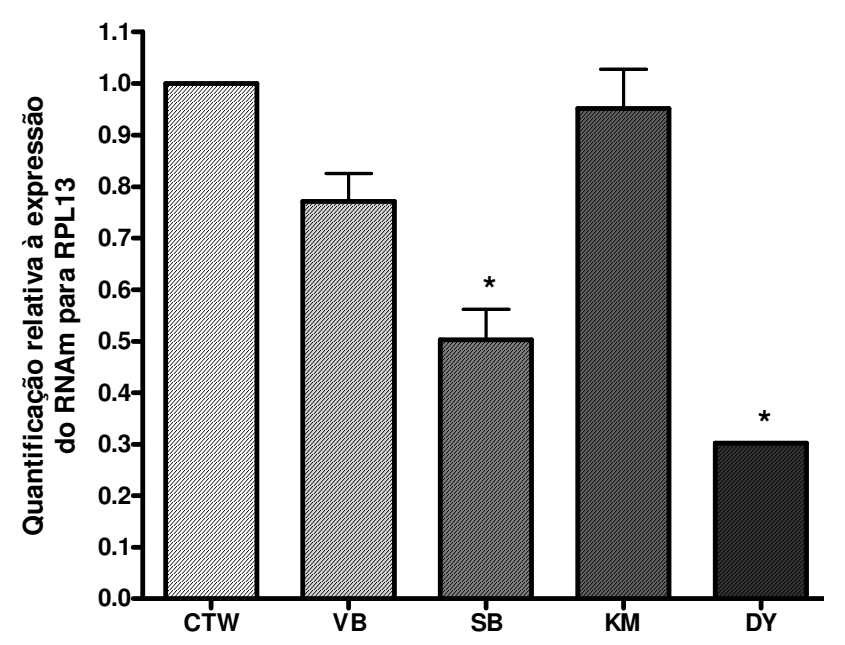

Figura 9- Expressão do RNAm para pró-colágeno tipo I por fibroblastos de polpa dental humana estimulados pelos materiais VB (Vitrebond), SB (Single Bond), KM (Ketac Molar), DY (Dycal) no período de 6 horas. Valores representativos das médias \pm desvio padrão. ${ }^{*}<\mathrm{CTW}, \mathrm{p}<0,05$. O ensaio foi realizado em triplicata. 


\section{EXPRESSÃO GÊNICA PARA SDF-1 $\alpha /$ CXCL12}

A expressão gênica para SDF-1 $\alpha /$ CXCL12 foi aumentada para o grupo controle estimulado apenas com LPS de E. coli em relação ao grupo controle não estimulado (Figura 10). Quando foram comparados os grupos sem o estímulo do LPS de E. coli, houve um aumento da expressão gênica para o grupo SB 10 (Single Bond 1:100) no período de 24 horas em relação ao período de 6 horas (Figura 11) e para o DY (Dycal) também no período de 24 horas em relação ao período de 6 horas (Figura 12).

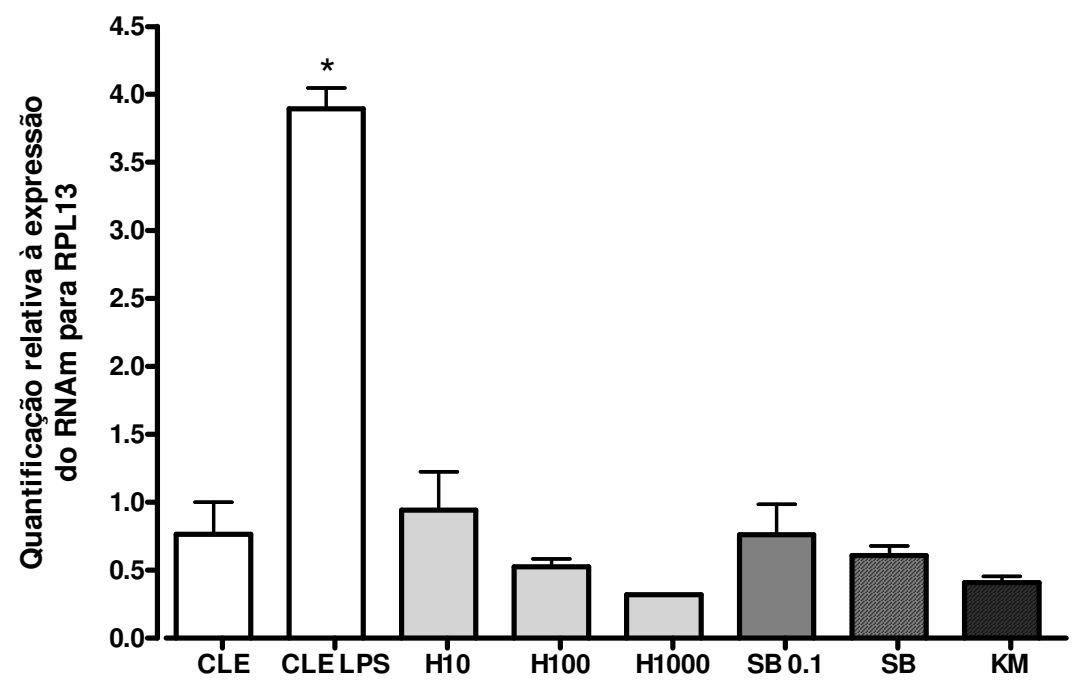

Figura 10- Expressão do RNAm para SDF-1 $\alpha /$ CXCL12 por fibroblastos de polpa dental humana estimulados pelos materiais H10 (HEMA 10 nM), H100 (HEMA $100 \mathrm{nM}$ ), H1000 (HEMA $1000 \mathrm{nM}$ ), SB 0,1 (Single Bond 1:10.000), SB (Single Bond) e KM (Ketac Molar) seguidos por LPS de E. coli no período de 24 horas. Valores representativos das médias \pm desvio padrão. * $>$ CLE LPS, $\mathrm{p}<0,05$. O ensaio foi realizado em triplicata. 


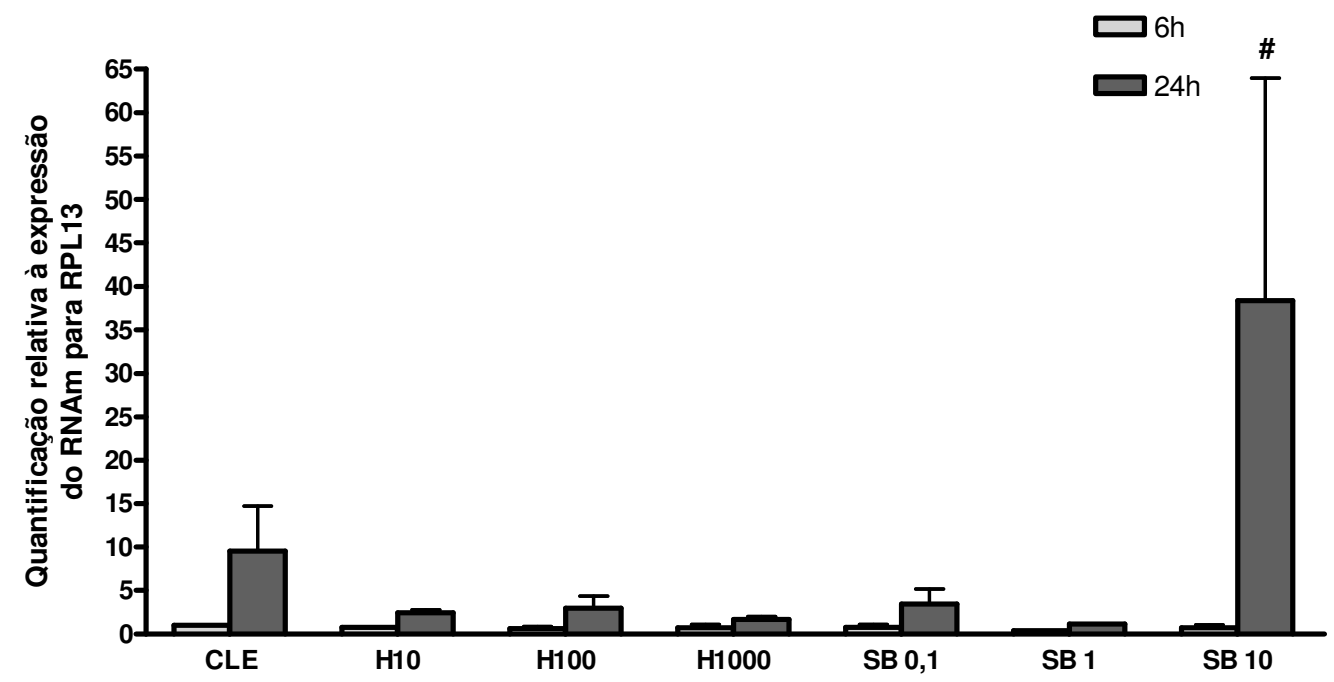

Figura 11- Expressão do RNAm para SDF-1 $\alpha /$ CXCL12 por fibroblastos de polpa dental humana estimulados pelos materiais H10 (HEMA $10 \mathrm{nM}$ ), H100 (HEMA $100 \mathrm{nM}$ ), H1000 (HEMA $1000 \mathrm{nM}$ ), SB 0,1 (Single Bond 1:10.000), SB 1 (Single Bond 1:1.000), SB 10 (Single Bond 1:100) nos períodos de 6 e 24 horas. Valores representativos das médias \pm desvio padrão. \# > SB 106 horas, $\mathrm{p}<0,05$. O ensaio foi realizado em triplicata.

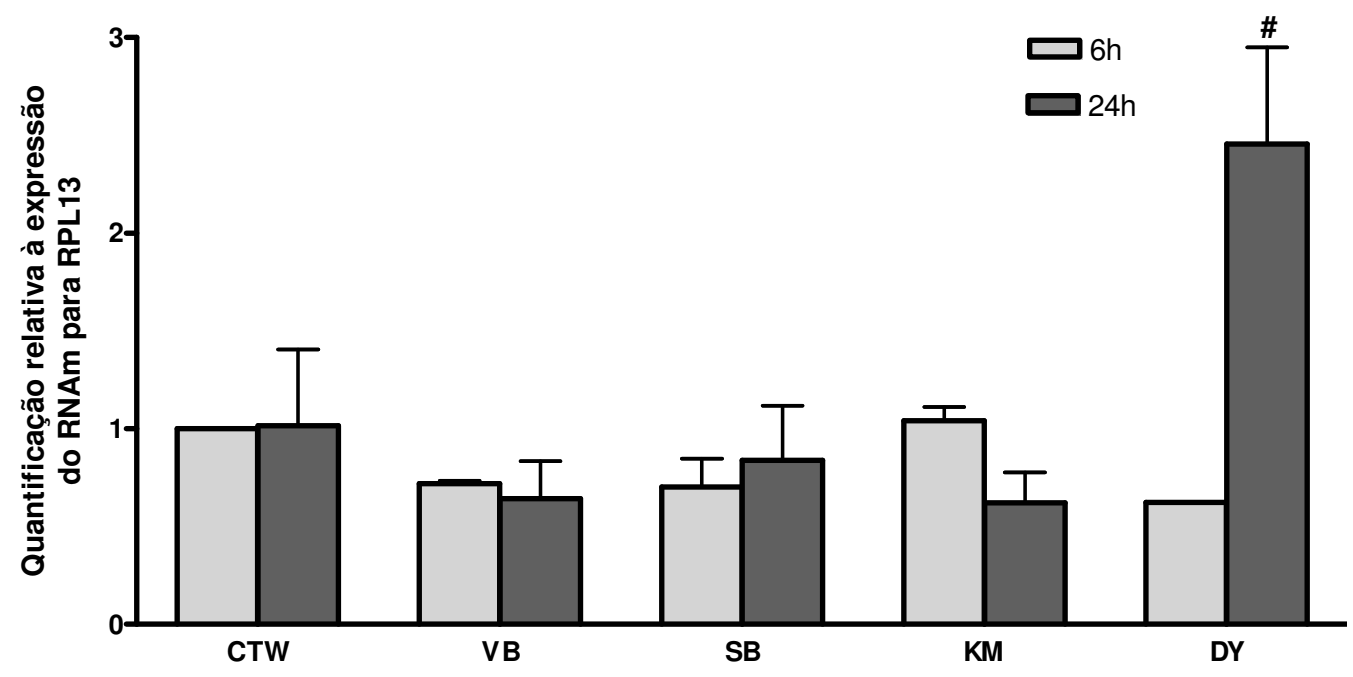

Figura 12- Expressão do RNAm para SDF-1 $\alpha /$ CXCL12 por fibroblastos de polpa dental humana estimulados pelos materiais VB (Vitrebond), SB (Single Bond), KM (Ketac Molar), DY (Dycal) nos períodos de 6 e 24 horas. Valores representativos das médias \pm desvio padrão. \# $>$ DY 6 horas, $\mathrm{p}<0,05$. O ensaio foi realizado em triplicata. 


\section{EXPRESSÃo GÊNICA PARA IL-6}

Os dados mostraram que houve uma diminuição da expressão gênica para IL-6 para o grupo H1000 (HEMA 1000 nM) em relação ao grupo controle CLE no período de 24 horas. Em contrapartida houve um aumento da expressão para o grupo SB 0,1 (Single Bond 1:10.000) no período de 6 horas em relação ao mesmo grupo no período de 24 horas (Figura 13).

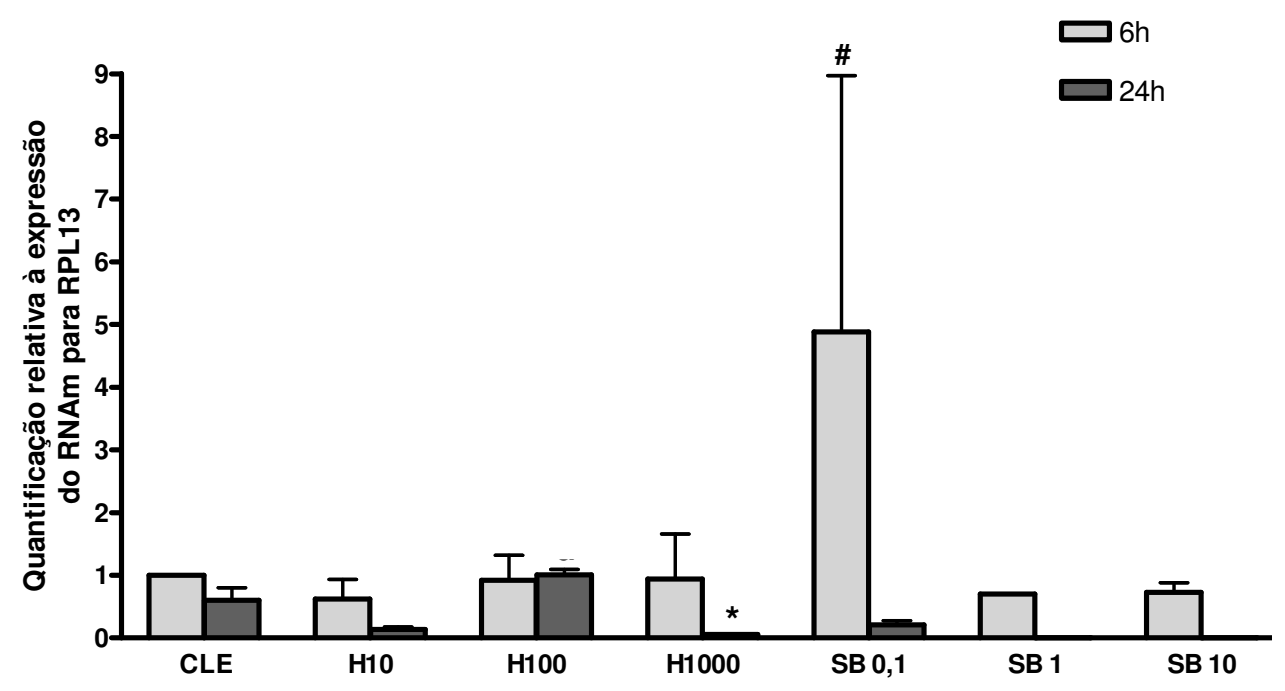

Figura 13- Expressão do RNAm para IL-6 por fibroblastos de polpa dental humana estimulados pelos materiais H10 (HEMA 10 nM), H100 (HEMA 100 nM), H1000 (HEMA 1000 nM), SB 0,1 (Single Bond 1:10.000), SB 1 (Single Bond 1:1.000), SB 10 (Single Bond 1:100) nos períodos de 6 e 24 horas. Valores representativos das médias \pm desvio padrão. * < CLE, p<0,05. \# > SB 0,1 24 horas, $\mathrm{p}<0,05$. Não foi detectada a expressão do gene IL-6 para os materiais SB 1 e SB 10 no período de 24 horas. O ensaio foi realizado em triplicata. 


\section{EXPRESSÃO GÊNICA PARA IL-8/CXCL8}

Houve uma diminuição da expressão gênica para IL-8/CXCL8 para os grupos: H10 (HEMA 10 nM), H100 (HEMA 100 nM), H1000 (HEMA 1000 nM), SB 0,1 (Single Bond 1:10.000), SB 1 (Single Bond 1:1.000), SB 10 (Single Bond 1:100) e DY (Dycal) comparado ao seu respectivo grupo controle no período de 6 horas (Figura 14 e 15). A expressão gênica foi aumentada para os grupos SB 10 (Single Bond 1:100) em relação a 6 horas (Figura 14) e para VB (Vitrebond) em relação ao seu grupo controle (CTW) em ambos os tempos experimentais (Figura 15). 


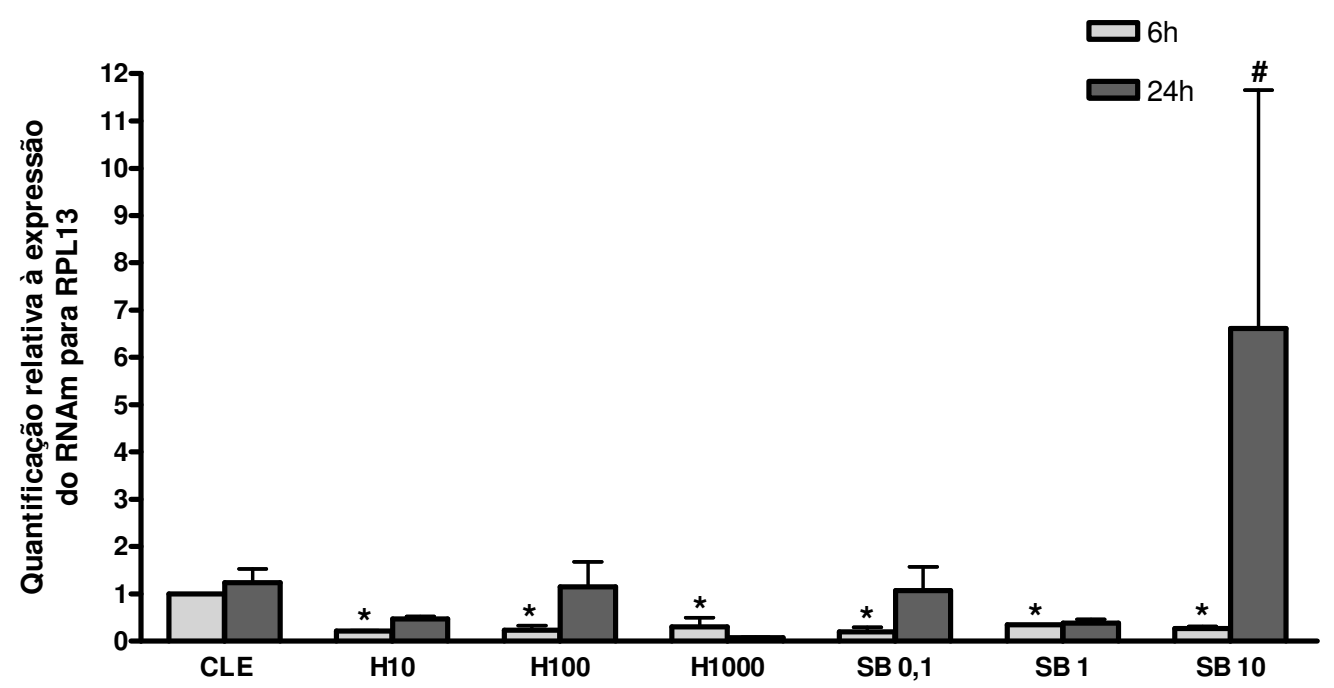

Figura 14- Expressão do RNAm para IL-8/CXCL8 por fibroblastos de polpa dental humana estimulados pelos materiais H10 (HEMA 10 nM), H100 (HEMA 100 nM), H1000 (HEMA 1000 nM), SB 0,1 (Single Bond 1:10.000), SB 1 (Single Bond 1:1.000), SB 10 (Single Bond 1:100) nos períodos de 6 e 24 horas. Valores representativos das médias \pm desvio padrão. ${ }^{*}<$ CLE 6 horas, $\mathrm{p}<0,05$. \# $>$ SB 106 horas, p<0,05. O ensaio foi realizado em triplicata.

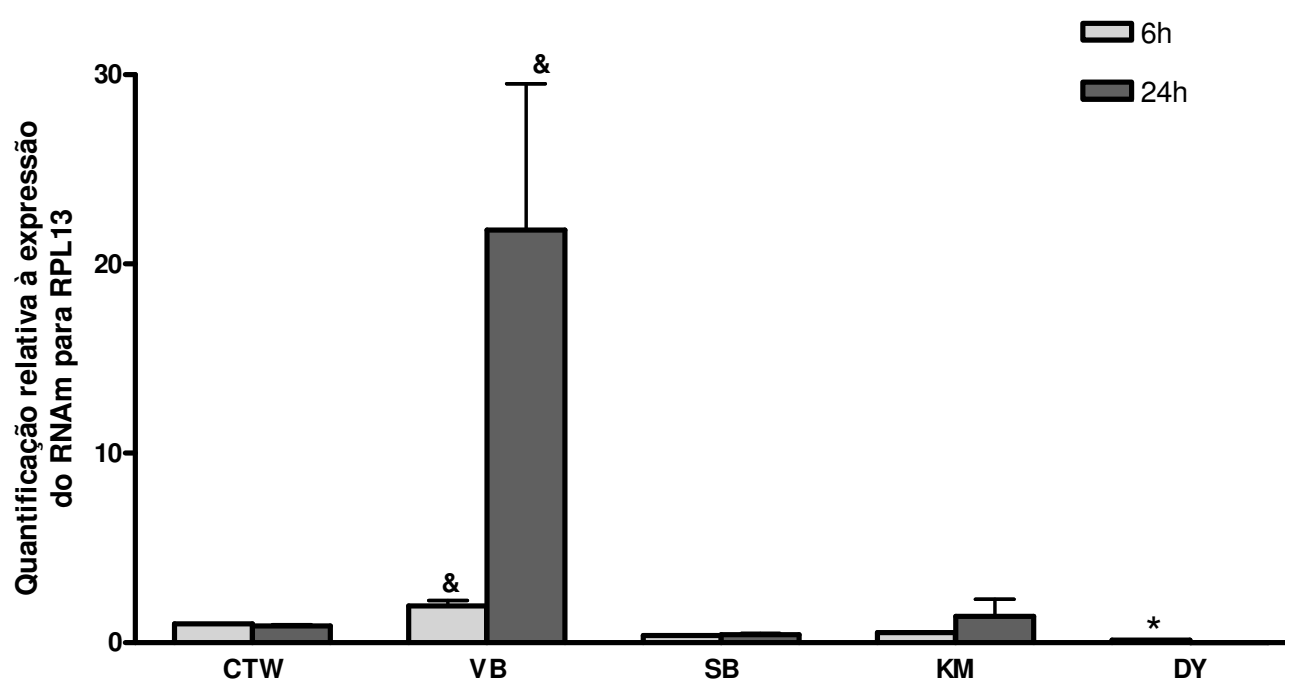

Figura 15- Expressão do RNAm para IL-8/CXCL8 por fibroblastos de polpa dental humana estimulados pelos materiais VB (Vitrebond), SB (Single Bond), KM (Ketac Molar), DY (Dycal) nos períodos de 6 e 24 horas. Valores representativos das médias \pm desvio padrão. * $<$ CTW 6 horas, p<0,05. \& $>$ CTW, p $<0,05$. O ensaio foi realizado em triplicata. 


\subsection{DeTECÇÃo DA PRODUÇÃo DE SDF-1 $\alpha /$ CXCL12, IL-6 E IL-8/CXCL8}

A produção de SDF-1 $\alpha /$ CXCL12, IL-6 e IL-8/CXCL8 pelos fibroblastos de polpa dental humana em cultura foi detectada por ELISA a partir da análise do sobrenadante após estímulo pelos materiais H10 (HEMA 10 nM), H100 (HEMA 100 nM), H1000 (HEMA 1000 nM), SB 0,1 (Single Bond 1:10.000), SB 1 (Single Bond 1:1.000), SB 10 (Single Bond 1:100) comparados ao grupo controle CLE, e VB (Vitrebond), SB (Single Bond), KM (Ketac Molar), DY (Dycal) comparados ao grupo controle CTW nos tempos experimentais de 6 e 24 horas.

Os resultados obtidos estão ilustrados nas Figuras 16, 17, 18, 19 e 20 e representam os grupos em que houve diferença estatisticamente significativa $(\mathrm{p}<0,05)$. 


\section{DETECÇÃo DA PRODUÇÃo DE SDF-1 $\alpha /$ CXCL12}

A análise dos resultados mostrou que a produção de SDF-1 $\alpha /$ CXCL12 foi diminuída para os grupos H10 (HEMA 10 nM), H100 (HEMA 100 nM), H1000 (HEMA 1000 nM) no período de 6 horas (Figura 16) e DY (Dycal) no período de 24 horas (Figura 17).

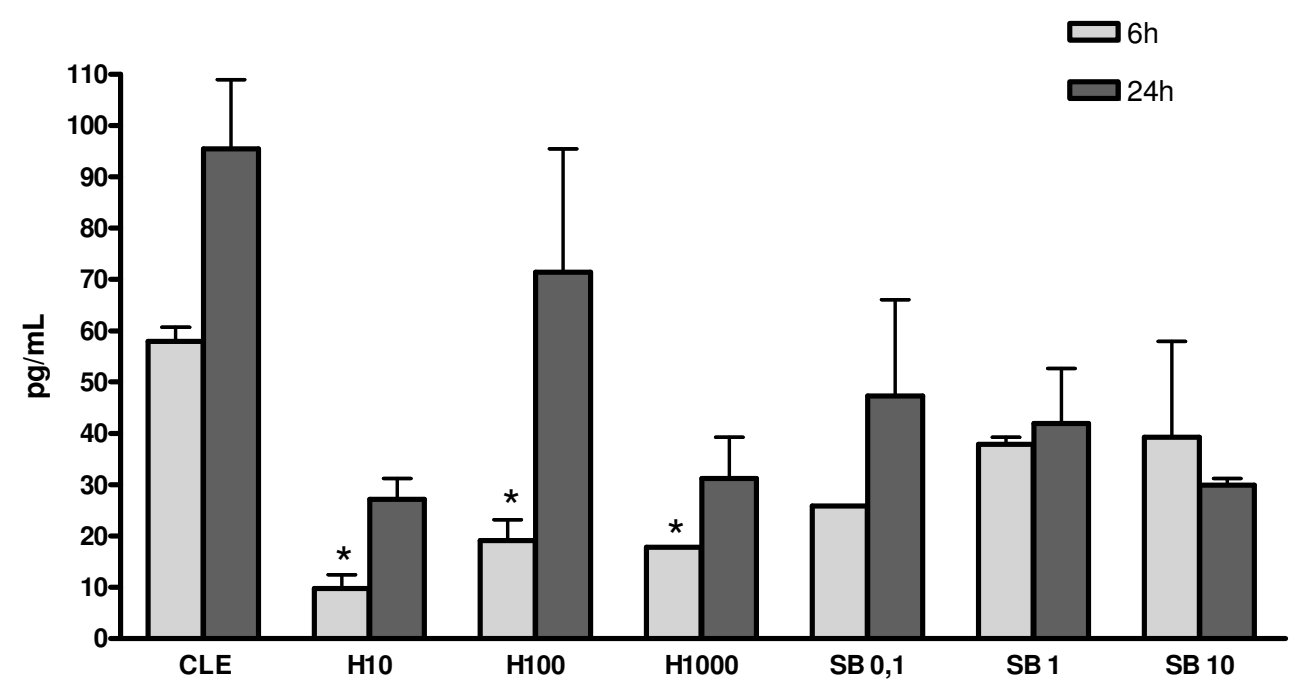

Figura 16- Produção in vitro de SDF-1 $\alpha /$ CXCL12 por fibroblastos de polpa dental humana estimulados pelos materiais H10 (HEMA 10 nM), H100 (HEMA 100 nM), H1000 (HEMA 1000 nM), SB 0,1 (Single Bond 1:10.000), SB 1 (Single Bond 1:1.000), SB 10 (Single Bond 1:100) nos períodos de 6 e 24 horas. Valores representativos das médias \pm desvio padrão. $*<$ CLE, $\mathrm{p}<0,05$. O ensaio foi realizado em duplicata.

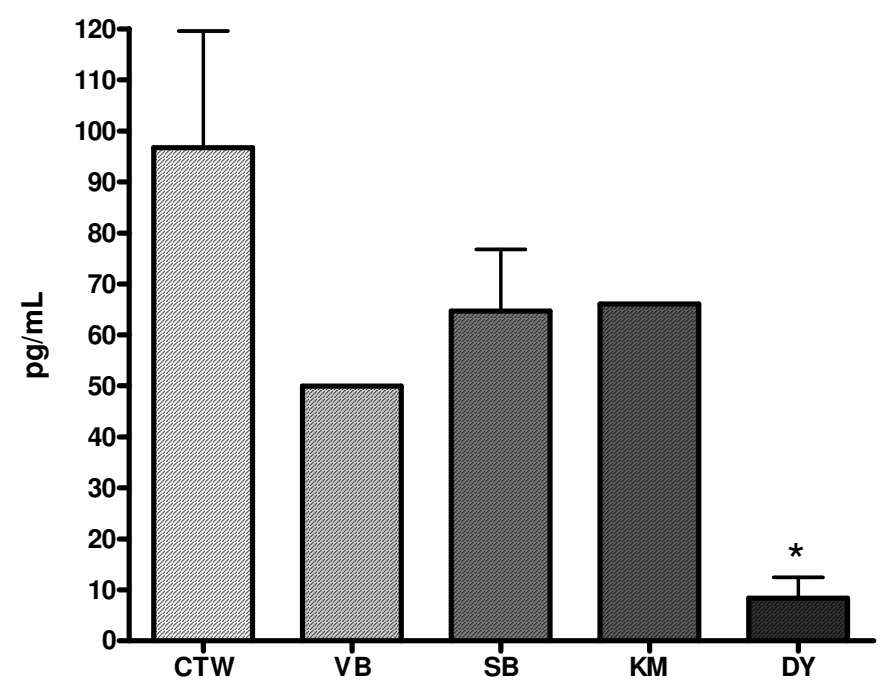

Figura 17- Produção in vitro de SDF-1 $\alpha /$ CXCL12 por fibroblastos de polpa dental humana estimulados pelos materiais VB (Vitrebond), SB (Single Bond), KM (Ketac Molar), DY (Dycal) no período de 24 horas. Valores representativos das médias \pm desvio padrão. $*<\mathrm{CTW}, \mathrm{p}<0,05$. O ensaio foi realizado em duplicata. 


\section{DETECÇÃo DA PRODUÇÃo DE IL-6}

De acordo com os dados houve um aumento estatisticamente significativo $(\mathrm{p}<0,05) \mathrm{da}$ produção de IL-6 para os grupos VB (Vitrebond) e KM (Ketac Molar) no período de 6 horas quando comparado ao grupo controle (Figura 18).

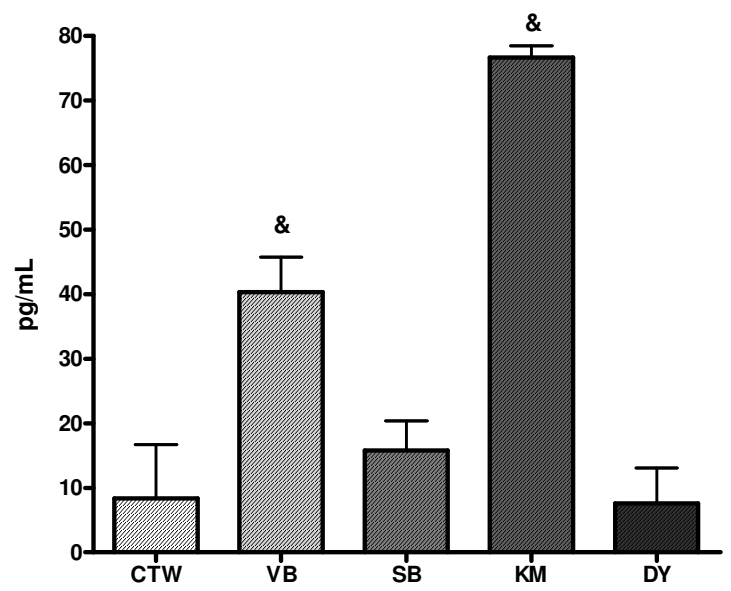

Figura 18- Produção in vitro de IL-6 por fibroblastos de polpa dental humana estimulados pelos materiais VB (Vitrebond), SB (Single Bond), KM (Ketac Molar), DY (Dycal) no período de 6 horas. Valores representativos das médias \pm desvio padrão. \& $>$ CTW, p $<0,05$. O ensaio foi realizado em duplicata. 


\section{DETECÇÃo DA PRODUÇÃo DE IL-8/CXCL8}

Os resultados mostraram que houve um aumento da produção de IL-8/CXCL8 para os grupos SB 1 (Single Bond 1:1.000) em 24 horas (Figura 19), VB (Vitrebond) em 6 e 24 horas e KM (Ketac Molar) em 24 horas em relação aos respectivos grupos controles (Figura 20). Houve uma diminuição da produção para os grupos SB 10 (Single Bond 1:100) 24 horas (Figura 19) e DY (Dycal) 6 e 24 horas (Figura 20).

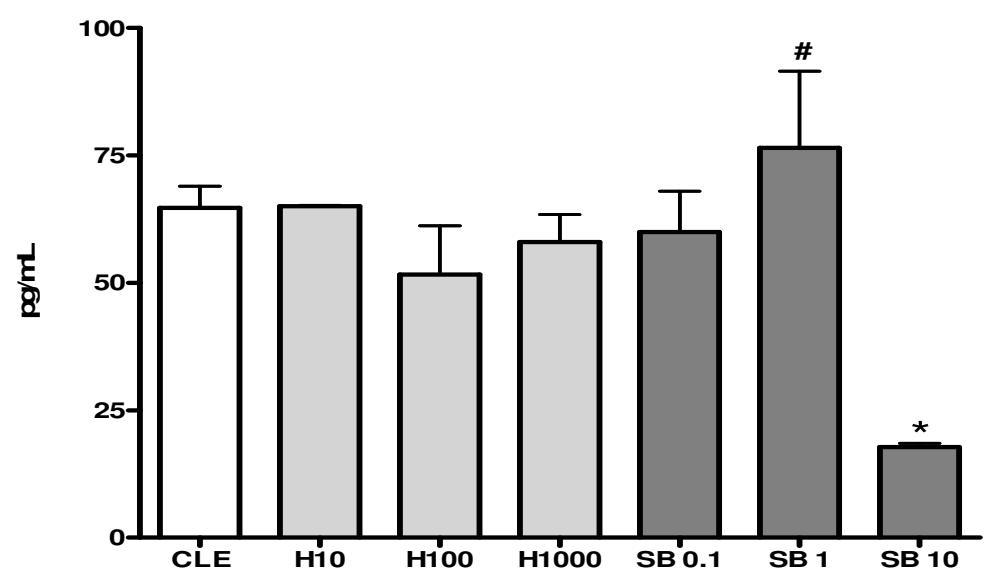

Figura 19- Produção in vitro de IL-8/CXCL8 por fibroblastos de polpa dental humana estimulados pelos materiais H10 (HEMA $10 \mathrm{nM}$ ), H100 (HEMA $100 \mathrm{nM}$ ), H1000 (HEMA $1000 \mathrm{nM}$ ), SB 0,1 (Single Bond 1:10.000), SB 1 (Single Bond 1:1.000), SB 10 (Single Bond 1:100) no período de 24 horas. Valores representativos das médias \pm desvio padrão. $*<$ CLE, $p<0,05$. \# $>$ CLE, $p<0,05$. O ensaio foi realizado em duplicata.

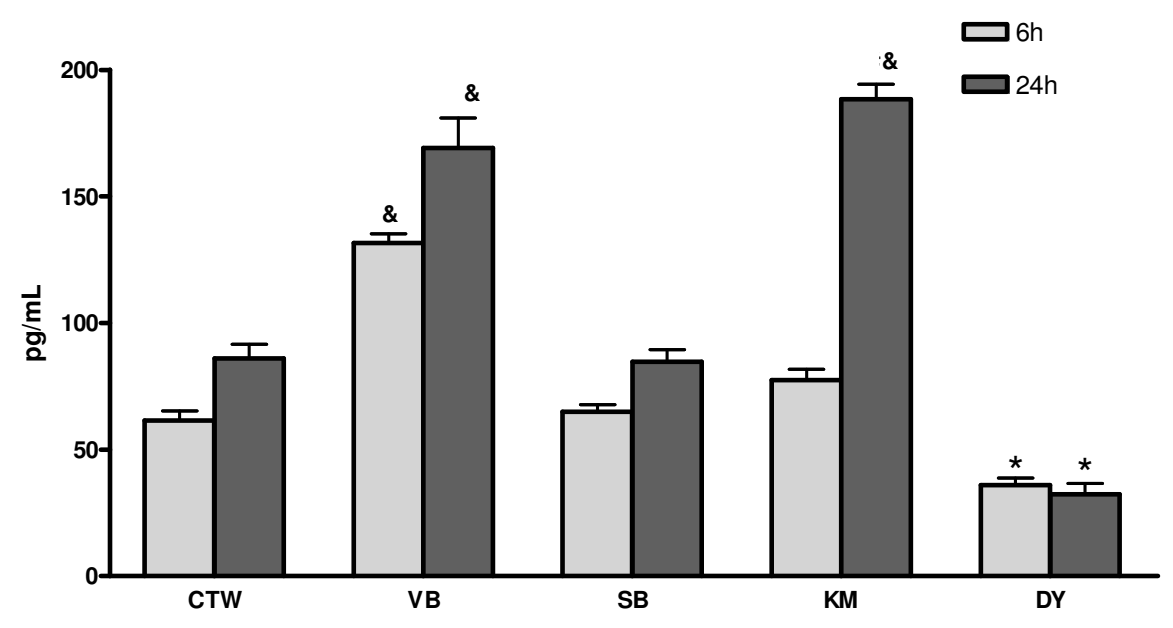

Figura 20- Produção in vitro de IL-8/CXCL8 por fibroblastos de polpa dental humana estimulados pelos materiais VB (Vitrebond), SB (Single Bond), KM (Ketac Molar), DY (Dycal) nos períodos de 6 e 24 horas. Valores representativos das médias \pm desvio padrão. $*<\mathrm{CTW}, \mathrm{p}<0,05$. \& $>\mathrm{CTW}, \mathrm{p}<0,05$. O ensaio foi realizado em duplicata. 



$$
E
$$





\section{DISCUSSÃo}

A dentina é um tecido conjuntivo calcificado e de natureza tubular. O número de túbulos varia de 40.000 a 70.000 por milímetro quadrado de acordo com a sua localização, aumentando à medida que se aproxima da polpa (GARBEROGLIO et al., 1976). O diâmetro dos túbulos varia de $1 \mu \mathrm{m}$ na junção amelodentinária a $3 \mu \mathrm{m}$ na superfície pulpar, portanto quanto mais próximo à polpa maior é o diâmetro e a quantidade de túbulos dentinários presentes, o que torna a dentina bastante permeável a substâncias químicas e ácidos bacterianos (COFFEY et al., 1970). Embora a remoção de dentina seja necessária para o tratamento da lesão de cárie, torna a polpa mais suscetível a irritantes químicos e bacterianos. A preservação da polpa dental é um dos passos mais importantes da prática clínica.

O uso de materiais para reabilitar as estruturas dentárias está em constante mudança para o benefício tanto do paciente quanto do profissional. O maior obstáculo é escolher a correta combinação de materiais de proteção do complexo dentino-pulpar e restauradores para o sucesso do tratamento. Todo o material utilizado deve satisfazer alguns requisitos como ser similar à estrutura dental em relação às propriedades físicas e mecânicas, ser biocompatível, possuir estabilidade de cor, proporcionar um ótimo polimento, entre outras. De fundamental importância é o efeito dos materiais restauradores colocados em várias profundidades na dentina e a resposta pulpar a esses materiais. Esses efeitos biológicos devem ser considerados com cuidado principalmente devido ao grande número de técnicas adesivas e de produtos que estão sendo introduzidos no mercado (MODENA et al., 2009).

Resinas compostas e adesivos dentinários, em sua maioria, são compostos por monômeros como o bis-glicidil metacrilato (BisGMA), uretano dimetacrilato (UDMA), trietileno glicol dimetacrilato (TEGDMA), 2-hidroxietil metacrilato (HEMA) entre outros e essas substâncias são citotóxicas quando em contato direto com fibroblastos (HANKS et al., 1991). HEMA é um dos componentes que mais são liberados dos adesivos dentais (GEURTSEN et al., 1998; GEURTSEN et al., 1999) e rapidamente se difunde através da dentina devido ao seu baixo peso molecular e hidrofilidade, evitando a diferenciação de células pulpares em odontoblastos (ABOUT et al., 2000) e podendo suprimir o crescimento de vários tipos celulares (GEURTSEN et al., 1998).

Durante a polimerização de resinas compostas ou sistemas adesivos à base de metacrilato, a conversão dos monômeros é incompleta levando à liberação dessas moléculas 
não reagidas para a polpa por meio dos túbulos dentinários ou locais de exposição pulpar (HANKS et al., 1994; PASHLEY, 1988). O oxigênio, presente durante a irradiação da luz, inibe o processo de polimerização dos monômeros pela formação de radicais não reativos de peróxido, que reagem com eles mesmos ou outros radicais resultando em produtos inativos (SHAWKAT et al., 2009). A baixa taxa de polimerização, influenciada pela intensidade de luz e duração da irradiação, sistema fotoiniciador, tipo e proporção dos monômeros está intimamente relacionada com a solubilidade do material na cavidade oral e com a quantidade de monômeros livres (RUEGGEBERG et al., 1990). Adesivos e resinas compostas livres de metacrilato parecem ser vantajosos em relação à biocompatibilidade, como as resinas à base de silorano, que possuem baixa solubilidade em água, causando menos efeitos adversos (WEINMANN et al., 2005).

Os cimentos de ionômero de vidro modificados por resina (CIVMR) foram desenvolvidos para superar os problemas dos cimentos de ionômero de vidro convencionais como alto tempo de presa, sensibilidade da técnica e fragilidade (BURKE et al., 2002). Entretanto, foram incorporados monômeros como o HEMA ou bis-GMA e a canforoquinona como fotoiniciador. A dentina, composta $50 \%$ em volume de mineral, $30 \%$ em volume de matriz orgânica e $20 \%$ em volume de fluido, devido à sua característica tubular e presença de líquido pode dissolver os cimentos de ionômero de vidro modificados por resina (MOUNT, 1994), consequentemente seus componentes podem ser liberados para o ambiente e se difundir através dos túbulos dentinários e atingir a polpa iniciando um processo inflamatório. Estudos mostram que a concentração de íons inorgânicos que são liberados dos CIVMR assim como dos CIV convencionais, como o $\mathrm{Sr}^{2+}, \mathrm{Al}^{3+}$ e $\mathrm{F}^{-}$são baixas para causar algum efeito citotóxico; entretanto, HEMA não polimerizado é liberado dos cimentos modificados por resina (STANISLAWSKI et al., 1999). A liberação de HEMA ocorre nas primeiras 24 horas após a polimerização e é a substância que compromete a biocompatibilidade dos CIVMR (GEURTSEN, 2000). Vários estudos demonstram que os cimentos de ionômero de vidro modificados por resina são citotóxicos para diferentes tipos celulares e tecidos devido à liberação de HEMA (ARANHA et al., 2006; COSTA et al., 2003; KAWAI et al., 2002; LAN et al., 2003; PALMER et al., 1999; SOUZA et al., 2006; STANISLAWSKI et al., 1999). Quando isso ocorre, sérios danos são causados à polpa, como por exemplo inflamação pulpar, podendo levar a respostas imunes em vários graus de gravidade (RAKICH et al., 1999). 
Muitos materiais são utilizados em capeamento pulpar direto e indireto e, um dos mais empregados é o cimento de hidróxido de cálcio (FARHAD et al., 2005). Esse material possui como vantagens a indução da mineralização, baixa toxicidade e alto $\mathrm{pH}$, responsável pela sua ação antibacteriana (FARHAD et al., 2005). O hidróxido de cálcio induz efeito inflamatório no qual em 7 dias é observado um processo inflamatório moderado, incluindo a presença de neutrófilos e células gigantes (HOLLAND et al., 2002). A intensidade da inflamação é gradualmente reduzida do sétimo ao décimo terceiro ou vigésimo dia (HOLLAND et al., 2002). Esses efeitos inflamatórios são caracterizados pela resposta do tecido e envolvem a permeabilidade vascular, fatores solúveis e a migração de leucócitos (IMHOF et al., 1997). Nesse processo um papel importante é atribuído à liberação de citocinas, quimiocinas ou leucotrieno- $\mathrm{B}_{4}$ por células residentes na indução do recrutamento de leucócitos para o foco inflamatório (FACCIOLI et al., 1990). O hidróxido de cálcio pode induzir o aumento na regulação de citocinas pró-inflamatórias durante a fase aguda da resposta inflamatória, assim como influenciar na regulação de citocinas anti-inflamatórias (REYES-CARMONA et al., 2011).

A importância de estudar os efeitos de materiais restauradores e de proteção do complexo dentino-pulpar está na melhora do uso e das indicações dos materiais no intuito de evitar danos pulpares. O complexo dentino-pulpar é capaz de se adaptar a uma série de estímulos, invocando resposta de defesa para manter a vitalidade.

A polpa dental humana é formada por um tecido conjuntivo especializado, altamente inervado e vascularizado, e sua porção central é constituída, em grande parte, por fibroblastos, que formam o principal grupo celular do tecido conjuntivo. A polpa é responsável por sustentar a dentina por meio de mecanismos homeostáticos de proteção. O processo de reparo pulpar é complexo e depende da extensão da agressão (SIMON et al., 2011). Os fibroblastos possuem um importante papel na remodelação da matriz extracelular, sintetizando componentes do tecido conjuntivo, principalmente fibrilas colágenas. Poucos trabalhos na literatura avaliam a produção de citocinas e quimiocinas por fibroblastos de polpa dental humana, estimulados por materiais utilizados em íntimo contato com o tecido pulpar.

No processo carioso, inicialmente se observa a presença de bactérias Gram-positivas em maior quantidade. Porém, à medida que a lesão cariosa progride em direção à interface dentina-polpa ocorrem mudanças na microflora, caracterizadas pela diminuição da proporção de bactérias aeróbicas Gram-positivas e um aumento de bactérias anaeróbicas Gram-negativas 
(HAMILTON, 2000), com o envolvimento de muitas células e mediadores da inflamação na resposta imune inicial à cárie (HAHN et al., 2007a; HAHN et al., 2007b). Quando a inflamação no tecido pulpar é induzida, muitos mediadores pró-inflamatórios são expressos, principalmente por fibroblastos de polpa dental humana (NAGAOKA et al., 1996; TOKUDA et al., 2001), assim como é observada a presença da enzima óxido nítrico sintase induzida (iNOS), precursora da formação de óxido nítrico, importante molécula com funções imunes (DI NARDO DI MAIO et al., 2004).

O principal responsável pelas respostas pulpares a antígenos é o sistema imune, que aumenta a produção de fatores inflamatórios (TSAI et al., 2005) e os fibroblastos são capazes de reconhecer antígenos e responder com a produção de mediadores da inflamação (YAMAJI et al., 1995). Uma grande descoberta da imunologia foi a descrição de receptores do tipo Toll (TLRs) e sua presença em fibroblastos (HATAKEYAMA et al., 2003; STAQUET et al., 2008). Os TLRs reconhecem as substâncias dos microrganismos que estimulam a imunidade inata e são conhecidos como padrões moleculares associados a patógenos (PAMPs) nas fases iniciais da resposta imune e induzem a expressão de vários mediadores da inflamação (GUTIERREZ-VENEGAS et al., 2005; SIPERT et al., 2010), citocinas (BOTERO et al., 2010; COIL et al., 2004; MORANDINI et al., 2010; TOKUDA et al., 2002; YANG et al., 2003) e quimiocinas (HATAKEYAMA et al., 2003; HOSOKAWA et al., 2005; STAQUET et al., 2008; YANG et al., 2003) via estimulação de NF-אB, um fator de transcrição responsável pela regulação da resposta inflamatória molecular (BOTERO et al., 2010; CHANG et al., 2005; FARGES et al., 2009).

O LPS de Escherichia coli possui a capacidade de exibir intensa atividade inflamatória, causando ativação celular e liberação de citocinas pró-inflamatórias (COIL et al., 2004; HOSOKAWA et al., 2005). A escolha de LPS de E.coli como um estímulo utilizado em sinergismo aos materiais se deve ao fato de que à medida que a lesão cariosa progride em direção à polpa, ocorre uma mudança no padrão microbiano (HAMILTON, 2000). Além do LPS de E. coli ser um estímulo comumente utilizado em ensaios experimentais de indução de resposta imunológica e pró-inflamatória (BOTERO et al., 2010; CHANG et al., 2005; COIL et al., 2004; KOGA et al., 1985; NAKANE et al., 1995; SIPERT et al., 2010; YAMAJI et al., 1995), sua estrutura é formada por um componente anfipático lípide A, localizado na superfície externa da membrana celular da bactéria, sendo que o número total de cadeias lipídicas do lípide A é o fator mais importante relacionado à imunogenicidade do antígeno. 
No caso do LPS de E. coli, estão presentes seis cadeias lipídicas do lípide A e exercem atividade inflamatória ótima (PARK et al., 2009), enquanto que lípides A com cinco cadeias, como a do LPS de P. gingivalis, são cem vezes menos ativos (HASHIMOTO et al., 2004). Fibroblastos pulpares produzem uma série de citocinas em resposta ao estímulo bacteriano (MATSUSHIMA et al., 1998; O’BOSKEY et al., 1998).

A concentração de $10 \mu \mathrm{g} / \mathrm{mL}$ de LPS de E. coli segundo trabalho de Nakane et al. (1995) aumentou a produção de DNA em células de polpa dental humana, entretanto diminuiu a produção de proteína. Concentração de $100 \mu \mathrm{g} / \mathrm{mL}$ de LPS inibiu a produção de DNA pelas células e diminuiu a produção de proteína e, $1 \mu \mathrm{g} / \mathrm{mL}$ não causou nenhuma mudança tanto na produção de DNA quanto de proteína (NAKANE et al., 1995). A concentração escolhida nesse trabalho foi a de $10 \mu \mathrm{g} / \mathrm{mL}$, valor que causasse alterações na produção de DNA e de proteína, mas não a ponto de inibir a produção de ambos. Os resultados do trabalho de He et al. (2007) mostraram que a concentração de $10 \mu \mathrm{g} / \mathrm{mL}$ de LPS de E. coli aumentou a produção de IL-11 por fibroblastos gengivais, assim como a produção de IL-6 (HE et al., 2007). A estimulação dos fibroblastos de polpa dental humana por LPS de E. coli após o estímulo com os materiais tentou mimetizar o que representaria a recorrência de cárie após a restauração do órgão dentário.

Os testes de biocompatibilidade e citotoxicidade são essenciais e recomendados para os materiais que são utilizados na área da saúde. A American Dental Association (ADA) recomenda uma sequência de testes de biocompatibilidade para os materiais dentários (CRAIG, 1997). A sequência consiste em testes iniciais, secundários e de uso. Nos testes iniciais são realizados ensaios in vitro para a citotoxicidade e para mutagênese para os materiais dentários e seus componentes.

A biocompatibilidade pode ser definida como a capacidade do material realizar a função a que foi proposto sem causar efeitos indesejáveis (WILLIAMS, 2003) como reações alérgicas, inflamatórias ou tóxicas, quando em contato com os tecidos vivos ou fluidos orgânicos. A biocompatibilidade compreende as interações dos tecidos e fluidos com um material. Quando o material é colocado em um tecido vivo gerará algum tipo de resposta biológica. A citotoxicidade pode resultar em um amplo espectro de efeitos, como alterações metabólicas e morte celular. Os testes de citotoxicidade são a primeira etapa para se assegurar a biocompatibilidade de um material (WATAHA, 2001). Algumas maneiras de avaliar a 
citotoxicidade podem ser por meio do ensaio de Trypan Blue e de MTT, ambos utilizados nesse trabalho.

Pelo ensaio de viabilidade celular, Trypan Blue, o material que causou morte celular em maior proporção foi o sistema adesivo Single Bond (SB 10) na concentração de 1:100, diminuindo para menos de $50 \%$ a quantidade de células viáveis no período de 6 horas. Para o ensaio de MTT, o mesmo material causou uma leve diminuição da respiração mitocondrial celular no mesmo período experimental, portanto com poucas células viáveis e menor taxa de metabolismo. Os resultados ficaram ainda mais expressivos no período de 24 horas. SB10 diminuiu a porcentagem de células viáveis para menos de $5 \%$ do número total de fibroblastos, assim como o metabolismo celular caiu consideravelmente.

Os efeitos citotóxicos desse material podem ser devido aos seus componentes ácidos, porque ocorreu uma mudança na cor do meio de cultura de vermelho para amarelo após ser aplicado na cultura de fibroblastos. Entretanto, quando o Single Bond foi polimerizado (SB), não se observou a mesma resposta, sugerindo-se que os efeitos citotóxicos diminuem pela diminuição da quantidade de substâncias livres.

A conversão de monômeros dos sistemas adesivos é incompleta, embora não exclusivamente pela presença do oxigênio, que inibe o processo de polimerização pela formação de radicais que reagem com eles mesmos ou outros radicais resultando em produtos inativos (SHAWKAT et al., 2009), levando à liberação desses monômeros não reagidos para o tecido pulpar (HANKS et al., 1994; PASHLEY, 1988). Foi relatado que monômeros, como o HEMA, são solúveis em meio aquoso (GEURTSEN et al., 1998) e estão presentes em adesivos como o Single Bond. Entretanto, nas condições em que o presente estudo foi realizado, quando o HEMA foi aplicado em várias concentrações (10 nM, 100 nM e 1000 nM) diretamente nos fibroblastos de polpa dental humana, não causou diminuição da viabilidade celular nem alterou as taxas de respiração mitocondrial celular. Deve-se levar em consideração que as concentrações utilizadas não foram baseadas nas concentrações usadas pelos fabricantes dos sistemas adesivos pois estes não informam exatamente a sua composição incluindo a concentração dos monômeros. Muitos trabalhos afirmam que os monômeros HEMA, bis-GMA e TEGDMA podem reduzir a síntese protéica, a síntese de DNA e a capacidade respiratória celular (BOUILLAGUET et al., 1996; HANKS et al., 1992). 
Na prática clínica a aplicação de sistema adesivo diretamente sobre a polpa como material de capeamento pulpar pode permitir a constante liberação de produtos não reagidos para a polpa, levando a uma resposta inflamatória persistente (GWINNETT et al., 1998; HEBLING et al., 1999a). A presença de partículas resinosas no tecido pulpar inicia uma resposta de corpo estranho, caracterizada pela presença de infiltrado inflamatório mononuclear e deficiência na formação de barreira mineralizada. A fagocitose de glóbulos poliméricos por macrófagos e a reação de corpo estranho podem levar a um atraso no recrutamento de fibroblastos e na diferenciação de células para a substituição de odontoblastos e formação de dentina reparativa e barreira mineralizada (GWINNETT et al., 1998). Polpas capeadas com sistema adesivo exibiram diferentes graus de inflamação com a predominância de células inflamatórias mononucleares (PEREIRA et al., 2000). Muitos trabalhos sobre citotoxicidade de sistemas adesivos afirmam que esses materiais causam algum tipo de dano em células pulpares ou em outros tipos celulares humanos ou não (CHEN et al., 2003; COSTA et al., 1999; DEMARCO et al., 2001; GROBLER et al., 2004; HEBLING et al., 1999a; MANTELLINI et al., 2003; SENGÜN et al., 2011).

Quando o LPS de E. coli foi colocado em contato com os fibroblastos após serem estimulados com os materiais HEMA (H10, H100, H1000) e Single Bond (SB; SB0,1; SB1; SB10) pelo período de 24 horas, notou-se, pelo teste de MTT, que houve diminuição significativa da respiração celular para os grupos SB1 e SB10. O LPS usado em sinergismo com os materiais para a estimulação das células causou alteração da atividade metabólica nos fibroblastos, sendo que o grupo mais afetado foi o SB10, assim como mostrado quando os fibroblastos foram estimulados apenas com esse material.

Embora o LPS de E. coli seja um potente estimulador de leucócitos, não está muito claro o efeito que produz em fibroblastos de polpa sadia. Além disso, os fibroblastos de polpa podem ter um padrão de indução de citocinas diferente de fibroblastos derivados de outras localizações (COIL et al., 2004). Coil et al. (2004) demonstraram em seu trabalho que fibroblastos de polpa dental humana são capazes de secretar consideráveis quantidades de IL6 quando estimulados por LPS de E. coli na concentração de $1 \mathrm{mg} / \mathrm{mL}$. Entretanto, na concentração utilizada neste trabalho de $10 \mu \mathrm{g} / \mathrm{mL}$ de LPS de E. coli não foi possível observar o aumento na secreção dessa citocina.

A síntese de colágeno é um evento muito importante para o reparo de lesões (OKIJI, 2002; TROWBRIDGE, 2002), sendo o colágeno produzido e secretado por fibroblastos de 
uma forma solúvel e depositado no ambiente extracelular. Embora alguns trabalhos mostrem que a síntese de colágeno por fibroblastos seja aumentada na presença de LPS (HE et al., 2009; YANG et al., 2007), os resultados do presente trabalho não mostraram nenhuma diferença estatisticamente significativa na produção de colágeno quando os fibroblastos foram estimulados pelos materiais HEMA (H10, H100, H1000) e Single Bond (SB; SB0,1; SB1; SB10) seguidos por LPS de E. coli. Segundo trabalho de Yang et al. (2007), a expressão de RNAm para pró-colágeno tipo I foi dependente da concentração de LPS utilizada, sendo que esta foi aumentada quando o LPS foi utilizado nas concentrações entre $0,005-0,5 \mu \mathrm{g} / \mathrm{mL}$, atingindo um pico na concentração de $0,1 \mu \mathrm{g} / \mathrm{mL}$. Quando a concentração de LPS foi de 1 $\mu \mathrm{g} / \mathrm{mL}$, a expressão do pró-colágeno tipo I foi inibida (YANG et al., 2007).

A expressão do RNAm para pró-colágeno tipo I diminuiu significativamente nos fibroblastos estimulados pelo sistema adesivo Single Bond na concentração de 1:100 (SB10) no período de 24 horas. Esse mesmo grupo experimental teve a viabilidade e o metabolismo celular diminuídos segundo os testes de Trypan Blue e MTT para o mesmo período, significando que esse material causou drástica morte celular. Por isso, sugere-se que a diminuição da expressão de pró-colágeno seja causada pela pequena quantidade de fibroblastos restantes. Para o período de 6 horas, houve tendência de diminuição da expressão gênica para os grupos H10; H100; H1000; SB0,1 e SB1 indicando que esses materiais afetaram a expressão de pró-colágeno tipo I, umas das principais funções dos fibroblastos. $\mathrm{O}$ teste de MTT e Trypan Blue para esses grupos não mostrou alterações no metabolismo e na viabilidade celular em relação ao grupo controle, o que mostra a importância da biologia molecular na avaliação das interações de materiais com as células. Houve aumento significativo da expressão do pró-colágeno tipo I no grupo controle de 24 horas em relação ao período de 6 horas. Os resultados também mostraram que houve diminuição da expressão do RNAm para pró-colágeno tipo I nos fibroblastos estimulados pelo Single Bond na sua forma polimerizada.

A produção e a expressão de SDF-1 $\alpha /$ CXCL12 foram verificadas e os resultados mostraram que fibroblastos de polpa dental humana produziram e expressaram esta proteína basalmente e sem estímulo algum, com um aumento no período de 24 horas em relação a 6 horas, o que corrobora o dado de que essa é uma quimiocina constitutiva e expressa em condições basais (FEDYK et al., 2001; KARIN, 2010). A presença de CXCL12 em condições basais torna os tecidos conjuntivos favoráveis à permanência de células dendríticas imaturas 
responsáveis pelo elo entre imunidade inata e adaptativa (RICART et al., 2011). A produção basal dessa quimiocina também pode exercer um papel importante na manutenção da homeostasia tecidual por meio da retenção de células-tronco hematopoiéticas nos tecidos conjuntivos (KARIN, 2010). Quando os fibroblastos foram estimulados apenas com LPS de E. coli houve aumento substancial da expressão de CXCL12, assim como demonstrado por Hosokawa et al. (2005). Esses mesmos autores demostraram um padrão de resposta concentração dependente e antagônico entre a produção de IL-8/CXCL8 e SDF-1 $\alpha /$ CXCL12. Com a adição de $P$. gingivalis inativado por calor, a concentração de IL-8/CXCL8 aumenta e de SDF-1 $\alpha /$ CXCL1 2 diminui. Entretanto, na presença de TNF- $\alpha$, IFN- $\gamma$, TGF- $\beta$, RANTES e MIP-3 $\alpha$ há um aumento da produção de CXCL12 (HOSOKAWA et al., 2005). Assim como ocorreu o aumento da expressão gênica para SDF-1 $\alpha /$ CXCL12 quando os fibroblastos foram estimulados por LPS de E. coli, o mesmo ocorreu quando essas células foram estimuladas pelo sistema adesivo Single Bond na concentração de 1:100 (SB10).

Há uma divergência na literatura em relação à expressão de SDF-1 $\alpha / C X C L 12$. Enquanto alguns trabalhos relatam a diminuição da sua expressão durante o processo inflamatório (FEDYK et al., 2001; HOSOKAWA et al., 2005), outros descrevem aumento na expressão dessa quimiocina e de seu receptor (JIANG et al., 2008; JIANG et al., 2008). O sistema adesivo Single Bond na concentração de 1:100 aumentou a expressão de SDF$1 \alpha /$ CXCL12 em 24 horas em relação ao período de 6 horas. Pode-se sugerir que o RNAm para CXCL12 foi produzido em um período anterior a 24 horas e permaneceu mesmo após a morte dos fibroblastos.

Em relação à produção de CXCL12, as três concentrações utilizadas do monômero HEMA (10 nM, 100 nM e $1000 \mathrm{nM})$ no período de 6 horas diminuíram a sua produção. Podese sugerir que a diminuição dos níveis protéicos se deve à redução na expressão de RNAm entre os períodos de 6 e 24 horas. Outro fator que deve ser levado em consideração é a ocorrência de regulação pós-transcricional da produção dessa quimiocina ou ainda a sua degradação como consequência ao estímulo. A viabilidade celular dos fibroblastos estimulados pelo HEMA não foi afetada, assim como a citotoxicidade desse monômero não alterou o metabolismo celular. Porém, esse material pode ter afetado a homeostasia celular, já que a CXCL12 é uma quimiocina relacionada à manutenção da homeostasia tecidual. 
IL-6 é uma citocina multifuncional, produzida e liberada localmente em tecidos pulpares inflamados e lesões periapicais por várias células, como linfócitos $\mathrm{B}$ e $\mathrm{T}$, monócitos/macrófagos, células endoteliais, fibroblastos, queratinócitos e osteoblastos. Essa interleucina possui papel importante na regulação das respostas imunes, como na indução da diferenciação final de células $\mathrm{B}$ na produção de anticorpos, ativação de células $\mathrm{T}$ para expressar receptor de IL-2 na superfície celular e aumentar a hematopoiese (ABBAS et al., 2003; BARKHORDAR et al., 1999; BARTON, 1997). Entretanto, essas reações tendem a se tornar incontroláveis e muito expressas durante a maioria dos estados inflamatórios podendo levar à destruição tecidual. Altos níveis de IL-6 estão ligados com a patogênese de várias doenças inflamatórias como a periodontite (TAKAHASHI et al., 1994). Além disso, tecidos pulpares humanos inflamados contêm maiores níveis de IL-6 que polpas sadias (BARKHORDAR et al., 1999). Isso indica que IL-6 derivada de células pulpares humanas pode ter papel importante na mediação da inflamação e resposta imune iniciada por infecção bacteriana.

A expressão de RNAm para IL-6 por fibroblastos se mostrou diminuída para o grupo HEMA 1000 nM (H1000) em relação ao grupo controle no período de 24 horas. De acordo com o trabalho de Trubiani et al. (2012), o tratamento de células mesenquimais de polpa dental humana com HEMA, nas concentrações de 3 e 5 mmol. $\mathrm{L}^{-1}$, aumentou a produção de mediadores da inflamação como IL-6 e IL-8, levando à conclusão de que a liberação de citocinas pró-inflamatórias por células mesenquimais de polpa, durante o tratamento com HEMA, pode guiar a cascata inflamatória mantendo a renovação celular fisiológica e consequentemente a regeneração do complexo dentino-pulpar (TRUBIANI et al., 2012). Em contrapartida, houve aumento da expressão para o grupo Single Bond 1:10.000 (SB0,1) no período de 6 horas em relação ao mesmo grupo no período de 24 horas. Esses resultados mostram que a expressão gênica para IL-6 pode ser afetada pelos materiais HEMA $1000 \mathrm{nM}$ (HEMA1000) e Single Bond 1:10.000 (SB0,1).

A expressão gênica de IL-8/CXCL8 por fibroblastos de polpa diminuiu nas três concentrações de HEMA (10 nM, 100 nM e 1000 nM) e nas três concentrações do sistema adesivo Single Bond (1:10.000, 1:1.000 e 1:100) no período de 6 horas. Quando estimulados pelo sistema adesivo Single Bond na concentração de 1:100 (SB10), a expressão gênica aumentou no período de 24 horas em relação ao período de 6 horas, embora o teste de Trypan Blue tenha mostrado que a porcentagem de células viáveis ficou em menos de $5 \%$ do número 
total de fibroblastos. O potencial inflamatório causado pelo sistema adesivo foi de extrema intensidade, que mesmo causando a morte celular foi possível determinar um aumento na expressão dessa quimiocina, assim como mostram estudos in vivo e in vitro (DE SOUZA COSTA et al., 2007; FERREIRA et al., 2009; HEBLING et al., 1999a). A produção de IL8/CXCL8 pelos fibroblastos quando estimulados por esse mesmo material (SB10) foi drasticamente diminuída em relação ao grupo controle, o que sugere ser devido à alta porcentagem de células mortas para esse grupo no período de 24 horas ou devido à ocorrência de regulação pós-transcricional.

O hidróxido de cálcio é considerado um excelente material para capeamento pulpar direto, preservando a viabilidade pulpar e induzindo a formação de barreira mineralizada (PEREIRA et al., 2000). A formação de tecido mineralizado pelo cimento de hidróxido de cálcio parece estar relacionada ao efeito necrótico causado pelo seu alto $\mathrm{pH}(12,5)$, devido aos íons hidroxila e aos íons cálcio (SCHRODER, 1985). O hidróxido de cálcio pode agir localmente como um tampão contra as reações ácidas produzidas pelo processo inflamatório e o seu $\mathrm{pH}$ alcalino pode neutralizar o ácido lático secretado pelos osteoclastos, prevenindo maiores destruições do tecido mineralizado (HEITHERSAY, 1975), e ativar a atividade da fosfatase alcalina, o que possui um importante papel na formação de tecido duro (GUO et al., 1978). O seu alto $\mathrm{pH}$ combinado com a presença de cálcio e íons hidroxila possui efeito na sinalização enzimática e consequente mineralização (TORNECK et al., 1983).

O efeito necrótico demora algumas horas e resulta em uma zona de necrose por liquefação subjacente ao cimento de hidróxido de cálcio e uma zona de necrose por coagulação em uma região mais profunda e próxima à polpa. A zona de necrose por coagulação parece estimular a formação de barreira mineralizada entre o material e o tecido pulpar sadio, ocorrendo a organização celular e a produção de colágeno dentro de 4 dias, seguidas da mineralização 3 dias depois (SCHRODER, 1985). Os resultados dos testes Trypan Blue e MTT para o hidróxido de cálcio mostraram que no período de 24 horas houve uma drástica diminuição tanto da viabilidade celular, menos de $10 \%$ de células viáveis do total, quanto da respiração mitocondrial, aproximadamente 28,5\%. Esses dados podem ser explicados pelo fato de que o hidróxido de cálcio promove necrose por coagulação, atuando de maneira semelhante à membrana basal existente entre os ameloblastos e odontoblastos primários em diferenciação e devido ao seu alto $\mathrm{pH}$ solubiliza fatores de crescimento, como o TGF- $\beta$ da dentina, podendo ser o mecanismo responsável pelo reparo pulpar e formação de 
barreira mineralizada (GROBLER et al., 2004; HEBLING et al., 1999a; HOLLAND, 1971; SMITH et al., 1995; TJÄDERHANE, 2002).

Quando o LPS de E. coli foi colocado em contato com os fibroblastos após serem estimulados com os materiais Vitrebond (VB) e Ketac Molar (KM) pelo período de 24 horas, notou-se, pelo teste de MTT, que houve diminuição significativa da respiração celular apenas para o grupo VB.

Em relação à síntese de colágeno, evento muito importante para o reparo de lesões (OKIJI, 2002; TROWBRIDGE, 2002), os resultados mostraram que houve diminuição da expressão do RNAm para pró-colágeno tipo I nos fibroblastos estimulados pelo cimento de hidróxido de cálcio em relação ao grupo controle no período de 6 horas. O processo inflamatório causado pelo cimento de hidróxido de cálcio pode ter reduzido a expressão do RNAm para pró-colágeno tipo I pelos fibroblastos. Fragiadaki et al. (2011) relataram que altas concentrações de TGF- $\beta$ são capazes de diminuir a expressão gênica de colágeno tipo I em fibroblastos murinos NIH3T3, o que pode ser justificado pelo fato do TGF- $\beta$ ser uma citocina comumente relacionada a eventos anti-inflamatórios (TSUNAWAKI et al., 1988). Quando os fibroblastos foram estimulados pelos materiais Vitrebond (VB), Ketac Molar (KM) e Dycal (DY) seguidos por LPS de E. coli., os resultados não mostraram nenhuma diferença estatisticamente significativa na produção de colágeno.

Os tipos e os níveis de citocinas ao redor de um biomaterial podem, inicialmente, levar a reações inflamatórias agudas e crônicas e tardiamente iniciar uma resposta cicatricial (BRODBECK et al., 2003). Segundo trabalho de Reyes-Carmona et al. (2011) o hidróxido de cálcio induziu aumento na regulação de citocinas pró-inflamatórias tempo-dependente durante a fase aguda da resposta inflamatória. A expressão de IL-1 $\beta$ e TNF- $\alpha$ aumentou significantemente nos tempos de 12, 24 e 72 horas. Esses dados sugerem que a presença do hidróxido de cálcio causou um impacto na sinalização intracelular que ocorre no local em que o material foi colocado. O aumento da expressão de IL-10, uma citocina com características anti-inflamatórias, foi observado ao mesmo tempo da fase aguda da inflamação (REYES-

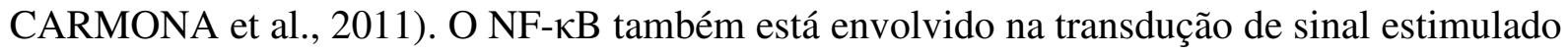
pelo hidróxido de cálcio (REYES-CARMONA et al., 2011) e induz a ativação de muitos tipos celulares em resposta a uma grande variedade de estímulos, o que inclui a secreção de citocinas pró-inflamatórias e na indução da expressão gênica da iNOS (MINAMIKAWA et al., 2009). 
O hidróxido de cálcio aumentou a expressão de SDF-1 $\alpha /$ CXCL12 no período de 24 horas em relação ao período de 6 horas. Há uma divergência na literatura em relação à expressão de SDF-1 $\alpha /$ CXCL12. Enquanto alguns trabalhos relatam a diminuição da sua expressão durante o processo inflamatório (FEDYK et al., 2001; HOSOKAWA et al., 2005), outros descrevem aumento na expressão dessa quimiocina e de seu receptor (JIANG et al., 2008; JIANG et al., 2008). O hidróxido de cálcio aumentou a expressão de SDF-1 $\alpha / C X C L 12$ em 24 horas em relação ao período de 6 horas. Novamente pode-se sugerir que o RNAm para CXCL12 foi produzido em um período anterior a 24 horas e permaneceu mesmo após a morte dos fibroblastos.

O hidróxido de cálcio em 24 horas diminuiu a produção de SDF-1 $\alpha /$ CXCL12. Pode-se sugerir que a diminuição dos níveis protéicos se deve à redução na expressão de RNAm entre os períodos de 6 e 24 horas. Outro fator que deve ser levado em consideração é a ocorrência de regulação pós-transcricional da produção dessa quimiocina ou ainda a sua degradação como consequência ao estímulo. Outra hipótese válida para o hidróxido de cálcio é a de que no período de 24 horas apenas $10 \%$ dos fibroblastos estavam viáveis, segundo o teste Trypan Blue.

Em relação à detecção da produção de IL-6, essa foi aumentada quando os fibroblastos foram estimulados pelos cimentos de ionômero de vidro modificado por resina, Vitrebond (VB) e convencional, Ketac Molar (KM) em relação ao grupo controle e o material Dycal (DY) não afetou a sua produção.

A expressão do RNAm para IL-8/CXCL8 pelos fibroblastos quando estimulados pelo hidróxido de cálcio mostrou-se diminuída no tempo experimental de 6 horas e ausente no período de 24 horas, o que pode ser explicado pelo fato de que em 24 horas, segundo os dados do ensaio de Trypan Blue, menos de $10 \%$ das células estavam viáveis e de acordo com o ensaio de MTT, o metabolismo celular diminuiu quatro vezes em relação ao grupo controle. Entretanto, a produção dessa quimiocina foi detectada tanto no período de 6 quanto de 24 horas, porém em níveis inferiores ao grupo controle. O cimento de ionômero de vidro modificado por resina Vitrebond (VB) aumentou significativamente a expressão do RNAm para IL-8/CXCL8 e os níveis produzidos dessa quimiocina em ambos os períodos experimentais. O cimento de ionômero de vidro convencional Ketac Molar estimulou a sua produção no período de 24 horas. 
As expressões de IL-6 e IL-8 são induzidas pelo fator nuclear NF-אB, uma molécula de transdução de sinal, que parece ser essencial para a produção dessas interleucinas. Mukaida et al. (1994) relataram que a transcrição do gene IL-8 necessita da ativação de vários fatores

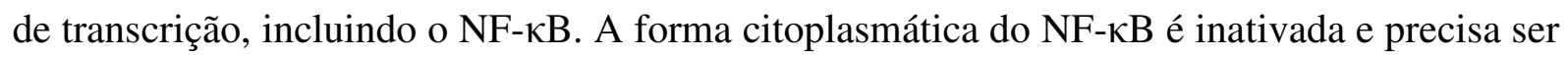
ativada por meio de vários estímulos como IL-1, TNF- $\alpha$ ou LPS de bactéria. Após a ativação,

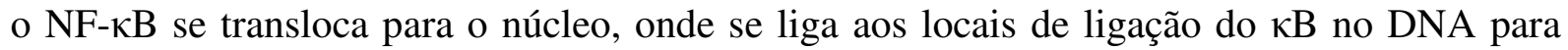
estimular a transcrição do gene (MUKAIDA et al., 1994). Tokuda et al. (2002) avaliaram o efeito da IL-10 na expressão de RNAm para IL-6 e IL-8 em fibroblastos de polpa dental humana e como resultado obtiveram que IL-10 inibiu a expressão dessas interleucinas pela

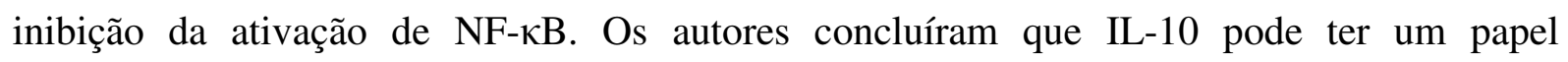
importante na inflamação pulpar seguida da cicatrização do tecido pulpar dental e que IL-10 pode ser útil na prevenção de doenças inflamatórias dentárias (TOKUDA et al., 2002).

O óxido nítrico é uma molécula mensageira intracelular (BREDT et al., 1990) de grande importância nos processos fisiológicos e patológicos e está envolvido no controle do crescimento celular, diferenciação, apoptose, vasodilatação e neurotransmissão. Quando presente em altas concentrações, pode atuar como potente molécula citotóxica desencadeando prejuízos aos tecidos (FOUAD, 2002). A indução da isoforma iNOS pode inibir a proliferação de fibroblastos e induzir a morte celular, o que contribui para o desequilíbrio entre destruição e reparo tecidual (KENDALL et al., 2002). Isso ocorre em processos inflamatórios, em que há um aumento da síntese de NO, como demonstrado em casos de pulpite (DI NARDO DI MAIO et al., 2004). Quando presente em pequenas quantidades, o NO regula o relaxamento muscular e protege contra a adesão de leucócitos e plaquetas na parede do vaso sanguíneo, podendo ser considerada uma molécula protetora e anti-inflamatória (FOUAD, 2002). O presente trabalho mostrou que a produção de NO foi diminuída quando os fibroblastos de polpa dental humana foram estimulados pelo cimento de ionômero de vidro Ketac Molar (KM). Os cimentos de ionômero de vidro são compostos de pó e líquido que quando misturados dão início a uma reação de presa do tipo ácido/base. Os CIV são extensamente utilizados na odontologia devido à sua biocompatibilidade, propriedades antibacterianas, adesão, coeficiente de expansão térmica linear próxima à estrutura dental e pela liberação de flúor (NAVARRO et al., 1998). A liberação de flúor ocorre com maior intensidade nas primeiras 24 a 48 horas, permanecendo em menor concentração por longos períodos (FORSTEN, 1991). A presença de fluoretos pode ter causado a diminuição na produção de NO. Segundo o trabalho de Bian et al. (2010) os níveis da atividade da NOS no plasma 
diminuíram quando coelhos foram expostos à alta concentração de flúor na água, levando à conclusão de que altas concentrações de flúor podem causar uma desordem no metabolismo de NO (BIAN et al., 2010). Embora muitos trabalhos relatem o aumento da produção de NO em diversos tecidos e tipos celulares quando colocados em contato com o fluoreto (BERGANDI et al., 2011; INKIELEWICZ-STEPNIAK et al., 2010; LIU et al., 2003), a comparação deve ser realizada com cautela porque a concentração de fluoreto utilizada nesses trabalhos é superior a que está contida nos cimentos de ionômero de vidro.

Muitas citocinas são detectadas no tecido pulpar durante a inflamação. Entre elas estão IL-1 $\alpha$, IL-1 $\beta$, IL-6, IL-8, IL-10, TNF- $\alpha$ (fator de necrose tumoral) e TGF- $\beta 1$ (fator transformador de crescimento) (ZEHNDER et al., 2003). Os fatores de crescimento podem ser liberados pela matriz dentinária durante os procedimentos dentais e na presença de erosão ou desmineralização causada pelo processo carioso (CASSIDY et al., 1997) e são capazes de regular o comportamento de células da polpa. O TGF- $\beta$ é expresso em uma grande variedade de células e três isoformas foram identificadas em mamíferos (TGF- $\beta 1$, TGF- $\beta 2$ e TGF- $\beta 3$ ), sendo que a mais expressa na dentina humana é a TGF- $\beta 1$. Esta participa do desenvolvimento dentário e na modulação da resposta do complexo dentino-pulpar durante o reparo tecidual, pela indução da proliferação, diferenciação e migração de odontoblastos e células da polpa (MELIN et al., 2000). Essas moléculas possuem um papel regulatório na biossíntese da matriz e produção de colágeno tipo 1 e são quimiotáticas para fibroblastos, neutrófilos e monócitos (TZIAFAS et al., 1998). Um aumento da expressão de TGF- $\beta 1$ foi detectada na camada odontoblástica e subodontoblástica em casos de pulpites irreversíveis quando comparado a polpas sadias (PIATTELLI et al., 2004). Segundo trabalho de Oussaief et al. (2011), na presença de TGF- $\beta 1$ a produção de nitrito é drasticamente diminuída e essa redução é

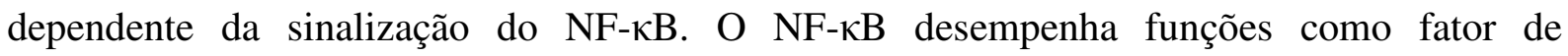
transcrição, pode ser encontrado em quase todos os tipos de células e está envolvido na resposta celular a estímulos como citocinas, radicais livres, antígenos virais e bacterianos

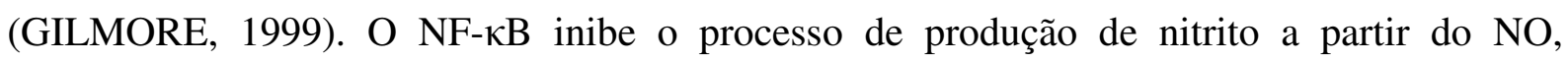
entretanto, segundo Oussaief et al. (2011), apenas a sinalização do NF-אB não é suficiente para suprimir a iNOS demonstrando que outros eventos estão envolvidos nesse caminho. Fibroblastos de ligamento periodontal humano quando estimulados por ProRoot MTA e cimento de Portland exibiram grandes quantidades de TGF- $\beta$ (FAYAZI et al., 2011), assim como no trabalho de Guven et al. (2007), em que demonstraram que ProRoot MTA também aumentou os níveis de TGF- $\beta$ em 24 e 72 horas em fibroblastos gengivais humanos (GUVEN 
et al., 2007). Outro trabalho do mesmo grupo de autores avaliou o efeito de dois sistemas adesivos autocondicionantes na produção de TGF- $\beta$ por fibroblastos gengivais humanos em cultura e mostrou que ambos adesivos foram capazes de induzir a síntese desse fator de crescimento apesar do potencial citotóxico desses materiais (GUVEN et al., 2009). Portanto, sugere-se que o Ketac Molar possa ter induzido a síntese de TGF- $\beta$ que por sua vez, por meio da sinalização do $\mathrm{NF}-\kappa \mathrm{B}$, inibiu a produção de nitrato a partir do $\mathrm{NO}$; entretanto outros experimentos são necessários para que essa hipótese se confirme.

O processo inflamatório, causado por bactérias cariogênicas quando atingem a dentina, em estágios avançados pode ser o gatilho para que as fibras nervosas nociceptivas medeiem a dor. Como qualquer outra inflamação, a pulpite está associada à degradação tecidual. Pelo menos três caminhos interdependentes são reconhecidos na quebra do tecido: caminho plasminogênio-dependente, caminho fagocitário e caminho metaloproteinases de matriz (MMP)-dependente (BIRKEDAL-HANSEN, 1993). As MMPs, produzidas por leucócitos e fibroblastos, participam da degradação da matriz extracelular em doenças inflamatórias crônicas, como a periodontite (BIRKEDAL-HANSEN, 1993) e também estão envolvidas na renovação fisiológica da matriz extracelular. As atividades das MMPs nos tecidos são moduladas por uma variedade de fatores locais, como os inibidores teciduais das metaloproteinases de matriz (TIMPs) (VISSE et al., 2003). Os TIMPs são pequenas proteínas multi-funcionais que formam complexos com as MMPs, bloqueando a ativação de pro-MMP latentes ou influencia a sua habilidade de hidrolisar um substrato em particular (BIRKEDALHANSEN, 1993).

A MMP-9 pertence ao grupo das gelatinases e pode ser de grande importância na quebra de tecido pulpar humano acometido pela inflamação. A MMP-9 pode ser detectada em células do tecido pulpar inflamado, o que sugere que essa metaloproteinase esteja estocada no citosol de odontoblastos, fibroblastos, células inflamatórias e células endoteliais e possa ser liberada em determinado estágio da reação inflamatória (O’BOSKEY et al., 1998). Os níveis de MMP-9 em tecidos inflamados são significantemente maiores que em tecidos pulpares sadios, diferentemente da MMP-2, cujos níveis foram menores em polpas sintomáticas quando comparado a polpas clinicamente normais (GUSMAN et al., 2002). Entretanto, não foi possível detectar sinais de amplificação do gene para MMP-9 no presente estudo nos períodos experimentais de 6 e 24 horas. Segundo o trabalho de Orsini et al., (2011), fibroblastos de polpa dental humana em cultura por 96 horas estimuladas por dois tipos de sistemas adesivos levaram a um aumento na expressão de MMP-2. Os autores acrescentam 
que o tempo influenciou a expressão dessa metaloproteinase, pois em 96 horas a expressão de MMP-2 foi muito maior que em 24 horas para ambos os adesivos testados (ORSINI et al., 2011). Portanto, sugere-se que os períodos experimentais de 6 e 24 horas não foram suficientes para a detecção da MMP-9. O trabalho de Lehmann et al. (2009) também mostrou que o tratamento de cavidades realizadas em terceiros molares sadios, com sistema adesivo e posterior cultura das fatias dos dentes, aumentou a produção de MMP-2, assim como sua atividade no complexo dentino-pulpar em 7 dias de tratamento (LEHMANN et al., 2009).

Muitos estudos demonstram que IL-1 e TNF- $\alpha$ podem ativar fibroblastos de polpa dental humana a produzir MMPs (CHANG et al., 2001) e a enzima COX-2 (CHANG et al., 2003). A destruição do tecido pulpar pode acontecer pela ativação de um ou mais caminhos degradativos distintos como caminho plasminogênio-dependente, caminho fagocitário, caminho metaloproteinase de matriz (MMP)-dependente (BIRKEDAL-HANSEN, 1993). Fibroblastos de polpa dental humana podem ser incluídos na rede de citocinas e essas células podem participar na orquestração de células de defesa em tecidos pulpares inflamados (YANG et al., 2003). No local em que a inflamação e destruição tecidual ocorreram, as células podem se comunicar umas com as outras por meio da interação de citocinas.

Outras avaliações devem ser realizadas para a compreensão da expressão de RNAm e produção de IL-6 e IL-8 por fibroblastos de polpa dental quando estimulados pelos materiais utilizados e por LPS de E. coli, como por exemplo a expressão de IL-10, que pode inibir a expressão das interleucinas avaliadas (TOKUDA et al., 2002) ou IL-1 $\alpha$ e TNF- $\alpha$, que aumentam a expressão das mesmas interleucinas (YANG et al., 2003). Da mesma forma a expressão de MMP-9 necessita de outros períodos experimentais para ampliar os achados deste estudo. 



$$
E
$$





\section{CONCLUSÕES}

O Single Bond e o HEMA, em várias concentrações, diminuíram a expressão e produção de moléculas envolvidas no processo inflamatório e, portanto, o uso de sistemas adesivos como material de capeamento pulpar deve ser visto com cautela devido ao seu grande efeito citotóxico quando em íntimo contato com o órgão pulpar.

Embora o hidróxido de cálcio tenha causado intensa morte celular e não tenha estimulado a produção dos mediadores da inflamação avaliados neste trabalho, sabe-se que esse evento parece ser fundamental para o processo de reparo do tecido pulpar e formação de barreira mineralizada.

Os cimentos de ionômeros de vidro utilizados aumentaram a produção de quimiocinas relacionadas ao processo inflamatório, podendo recrutar células e moléculas para o local da agressão e consequentemente favorecendo o reparo tecidual e, portanto, esses materiais, embora não tenham causado morte de grande número celular, devem ser utilizados com restrições. 

Referências

Biblungráficas 



\section{REFERÊNCIAS}

Abbas A, Lichtman A. Cytokines. In: Abbas A, Lichtman A, editors. Cellular and molecular immunology. 5 ed. Philadelphia: Saunders; 2003. p. 243-74.

Abbas A, Lichtman A. Innate Immunity In: Abbas A, Lichtman A, editors. Cellular and molecular immunology. 5 ed. Philadelphia: Saunders; 2003.

Abbas A, Lichtman A. Properties and Overview of Immune Responses. In: Abbas A, Lichtman A, editors. Cellular and molecular immunology. 5 ed. Philadelphia: Saunders; 2003.

About I, Bottero MJ, de Denato P, Camps J, Franquin JC, Mitsiadis TA. Human dentin production in vitro. Exp Cell Res. 2000;258(1):33-41.

Ansteinsson VE, Samuelsen JT, Dahl JE. Filler particles used in dental biomaterials induce production and release of inflammatory mediators in vitro. J Biomed Mater Res B Appl Biomater. 2009;89(1):8692.

Aranha AMF, Giro EMA, Souza PPC, Hebling J, Costa CAS. Effect of curing regime on the cytotoxicity of resin-modified glass-ionomer lining cements applied to an odontoblast-cell line. Dent Mat. 2006;22:864-69.

Archer S. Measurement of nitric oxide in biological models. FASEB J. 1993;7(2):349-60.

Barkhordar R, Ghani Q, Russell T, Hussain M. Interleukin-1beta activity and collagen synthesis in human dental pulp fibroblasts. J Endod 2002;28(3):157-9.

Barkhordar RA, Hayashi C, Hussain MZ. Detection of interleukin -6 in human dental pulp and periapical lesions. Endod Dent Traumatol. 1999;15:26-7.

Barton BE. IL-6: insights into novel biological activities. Clin immunol immunopathol. 1997;85:1620.

Bergandi L, Aina V, Malavasi G, Morterra C, Ghigo D. The toxic effect of fluoride on MG-63 osteoblast cells is also dependent on the production of nitric oxide. Chem Biol Interact. 2011;190(23):179-86.

Bergenholtz G, Nagaoka S, Jontell M. Class II antigen expressing cells in experimentally induced pulpitis. Int Endod J. 1991;24:8-14.

Berggreen E, Heyeraas KJ. The role of sensory neuropeptides and nitric oxide on pulpal blood flow and tissue pressure in the ferret. J Dent Res. 1999;78:1535-43.

Bhaskar SN. Orban's oral histology and embryology. 9 ed. St. Louis: CV Mosby; 1980.

Bian J, Lin X, Yang X, Fan T, Zhu Q. Changes of certain oxidative, anti-oxidative and vascular function indexes of New Zealand rabbit exposed by high-fluoride. Wei Sheng Yan Jiu. 2010;39(6):751-4.

Birkedal-Hansen H. Role of matrix metalloproteinases in human periodontal diseases. J Periodontol. 1993;64:474-84. 
Botero TM, Son SJ, Vodopyanov D, Hasegawa M, Shelburne CE, Nor JE. MAPK signaling is required for LPS-induced VEGF in pulp stem cells. J Dent Res. 2010;89:264-9.

Bouillaguet S, Wataha J, Hanks CT, Ciucci B, Holz J. In vitro cytotoxicity and dentin permeability of HEMA (2-hydroxyethyl methacrylate). J Endod. 1996;22:244-8.

Brännström M, Astrom A. The hydrodynamics of the dentin: its possible relationship to dentinal pain. Int Dent J. 1972;22:219.

Brännström M, Nyborg H. Pulpal reaction to composite resin restorations. J Prothet Dent. 1972;27:181-9.

Bredt DS, Snyder SH. Isolation of nitric oxide synthetase, a calmodulin-requiring enzyme. Biochemistry. 1990;87:682-5.

Breschi L, Mazzoni A, Nato F, Carrilho M, Visintini E, Tjäderhane L, et al. Chlorhexidine stabilizes the adhesive interface: a 2-year in vitro study. Dent Mater. 2010;26(4):320-5.

Breschi L, Mazzoni A, Ruggeri A, Cadenaro M, Di Lenarda R, De Stefano Dorigo E. Dental adhesion review: aging and stability of the bonded interface. Dent Mater. 2008;24:90-101.

Brodbeck WG, Voskerician G, Ziats NP, Nakayama Y, Matsuda T, Anderson JM. In vivo leukocyte cytokine mRNA responses to biomaterials are dependent on surface chemistry. J Biomed Mater Res A. 2003;64(2):320-9.

Burke FJ, Fleming GJ, Owen FJ, Watson DJ. Materials for restoration of primary teeth: 2. Glass ionomer derivatives and compomers. Dent Update. 2002;29(1):10-4, 6-7.

Carmignani M, Volpe A, Boscolo P. Catecholamine and nitric oxide systems as targets of chronic lead exposure in inducing selective functional impairment. Life Sci 2000;68:401-15.

Carrilho MR, Geraldeli S, Tay F, de Goes MF, Carvalho RM, Tjäderhane L, et al. In vivo preservation of the hybrid layer by chlorhexidine. J Dent Res. 2007;86(6):529-33.

Cassidy N, Fahey M, Prime SS, Smith AJ. Comparative analysis of transforming growth factor-b isoforms 1-3 in human and rabbit dentine matrices. Arch Oral Biol. 1997;42:219-23.

Cavalcanti BN, Rode SdM, França CM, Marques MM. Pulp capping materials exert an effect on the secretion of IL-1 $\beta$ and IL-8 by migrating human neutrophils. Braz Oral Res. 2011;25(1):13-8.

Cavalcanti BN, Rode SM, Marques MM. Cytotoxicity of substances leached or dissolved from pulp capping materials. Int Endod J. 2005;38:505-9.

Chan C, Lan W, Chang M, Chen Y, Lan W, Chang H. Effects of TGF-beta s on the growth, collagen synthesis and collagen lattice contraction of human dental pulp fibroblasts in vitro. Arch Oral Biol. 2005;50(5):469-79.

Chang J, Zhang C, Tani-Ishii N, Shi S, Wang CY. NF-kappaB activation in human dental pulp stem cells by TNF and LPS. J Dent Res. 2005;84:994-8.

Chang YC, Yang SF, Hsieh YS. Regulation of matrix metalloproteinase-2 production by cytokines and pharmacological agents in human pulp cell cultures. J Endod. 2001;27(11):679-82. 
Chang YC, Yang SF, Huang FM, Liu CM, Tai KW, Hsieh YS. Pro-inflammatory cytokines induces cyclooxygenase-2 mRNA and protein expression in human pulp cell cultures. J Endod. 2003;29(3):201-4.

Chen RS, Liu CC, Tseng WY, Jeng JH, Lin CP. Cytotoxicity of three dentin bonding agents on human dental pulp cells. J Dent. 2003;31(3):223-9.

Cho E, Kopel H, White SN. Moisture susceptibility of resin-modified glass-ionomer materials. Quint Int. 1995;26:351-8.

Clancy RM, Abramson SB. Nitric oxide: a novel mediator of inflammation. Proc Soc Exp Biol Med. 1995;55:105-11.

Coffey CT, Ingram MJ, Bjorndal A. Analysis of human dentinal fluid. Oral Surg. 1970;30(6):835-7.

Coil J, Tam E, Waterfield J. Proinflammatory cytokine profiles in pulp fibroblasts stimulated with lipopolysaccharide and methyl mercaptan. J Endod. 2004;30(2):88-91.

Cooper PR, Takahashi Y, Graham LW, Simon S, Imazato S, Smith AJ. Inflammation-regeneration interplay in the dentine-pulp complex. J Dent. 2010;38(9):687-97.

Costa CAS, Hebling J, Garcia-Godoy F, Hanks CT. In vitro cytotoxicity of five glass-ionomer cements. Biomaterials. 2003;24:3853-58.

Costa CAS, Oliveira MF, Giro EMA, Hebling J. Biocompatibility of resin-based materials as pulpcapping agents. Int Endod J. 2003;36:831-9.

Costa CAS, Vaerten MA, Edwards CA, Hanks CT. Cytotoxic effects of current dental adhesive systems on immortalized odontoblast cell line MDPC-23. Dent Mat. 1999;15:434-41.

Cox CF, Keall CL, Keall HJ, Ostro E, Bergenholtz G. Biocompatibility of surface-sealed dental materials against exposed pulps. J Prothet Dent. 1987;57:1-8.

Craig RG. Restorative dental materials. St. Louis: Mosby-Year Book Inc; 1997.

D’Souza R. Development of the pulpodentin complex. In: Hargreaves K, Goodis H, editors. Seltzer and Bender's Dental Pulp. 1 ed. Carol Stream: Quintessence publishing co; 2002. p. 13-40.

da Silva LP, Issa JP, Del Bel EA. Action of nitric oxide on healthy and inflamed human dental pulp tissue. Micron. 2008;39(7):797-801.

Dahlén G, Haapasalo M. Microbiologia da periodontite apical. In: Orstavik D, Ford T, editors. Fundamentos da endodontia. São Paulo: Editora Santos; 2004. p. 106-30.

de Souza Costa CA, Hebling J, Garcia-Godoy F, Hanks CT. In vitro cytotoxicity of five glass-ionomer cements. Biomaterials. 2003;24:3853-58.

de Souza Costa CA, Teixeira HM, Lopes do Nascimento AB, Hebling J. Biocompatibility of resinbased dental materials applied as liners in deep cavities prepared in human teeth. J Biomed Mater Res B Appl Biomater. 2007; 81(1):175-84.

Demarco FF, Tarquinio SBC, Jaeger MMM, Araújo VC, Matson E. Pulp response and citotoxicity evaluation of 2 dentin bonding agents. Quint Int. 2001;32(3):211-20. 
Di Nardo Di Maio F, Lohinai Z, D'Arcangelo C, De Fazio PE, Speranza L, De Lutiis MA, et al. Nitric oxide synthase in healthy and inflamed human dental pulp. J Dent Res. 2004;83(4):312-6.

Faccioli LH, Souza GEP, Cunha FQ, Poole S, Ferreira SH. Recombinant interleukin-1 and tumor necrosis factor induce neutrophil migration "in vivo" by indirect mechanisms. Agents Actions. 1990;30(3-4):344-9.

Farges JC, Keller JF, Carrouel F, Durand SH, Romeas A, Bleicher F, et al. Odontoblasts in the dental pulp immune response. J Exp Zool B Mol Dev Evol. 2009;321B(5):425-36.

Farhad A, Mohammadi Z. Calcium hydroxide: a review. Int Dent J. 2005;55(5):293-301.

Fayazi S, Ostad SN, Razmi H. Effect of ProRoot MTA, Portland cement, and amalgam on the expression of fibronectin, collagen I, and TGF- $\beta$ by human periodontal ligament fibroblasts in vitro. Indian J Dent Res. 2011;22(2):190-4.

Fedyk ER, Jones D, Critchley HO, Phipps RP, Blieden TM, Springer TA. Expression of stromalderived factor-1 is decreased by IL-1 and TNF and in dermal wound healing. J Immunol. 2001;166(9):5749-54.

Felaco M, Di Maio FD, De Fazio P, D'Arcangelo C, De Lutiis MA, Varvara G, et al. Localization of the e-NOS enzyme in endothelial cells and odontoblasts of healthy human dental pulp. Life Sci. 2000;68:297-306.

Ferracane JL, Condon JR. Rate of elution of leachable components from composite. Dent Mat. 1990;6:282-7.

Ferreira DC, Brito DG, Cavalcanti BN. Cytokine production from human primary teeth pulp fibroblasts stimulated by different pulpotomy agents. J Dent Child. 2009;76(3):194-8.

Forsten L. Fluoride release and uptake by glass ionomers. Scand J Dent Res. 1991;99(3):241-5.

Fouad AF. Molecular mediators of pulpal inflammation. In: Hargreaves K, Goodis H, editors. Seltzer and Bender's Dental Pulp. Carol Stream: Quintessence publishing Co; 2002. p. 247-79.

Fragiadaki M, Ikeda T, Witherden A, Mason RM, Abraham D, Bou-Gharios G. High doses of TGF- $\beta$ potently suppress type I collagen via the transcription factor CUX1. Mol Biol Cell. 2011;22(11):183644.

Freund M, Munksgaard EC. Enzymatic degradation of Bis-GMA/TEGDMA polymers causing decreased microhardeness and greater wear in vitro. Scand J Dent Res. 1990;98:351-5.

Garberoglio R, Brännström M. Scanning electron microscopic investigation of human dentinal tubules. Arch Oral Biol. 1976;21(6):355-62.

Gemmell E, Marshall RI, Seymour GJ. Cytokines and prostaglandins in immune homeostasis and tissue destruc-tion in periodontal disease. Periodontol 2000. 1997;14:112-43.

Gerzina TM, Hume WR. Diffusion of monomers from bonding resin-resin composite combinations through dentine in vitro. J Dent. 1996;24:125-8.

Geurtsen W. Biocompatibility of resin-modified filling materials. Crit Rev Oral Biol Med. 2000;11(3):333-55. 
Geurtsen W, Lehman F, Spahl W, Leyhausen G. Cytotoxicity of 35 dental resin composite monomers/additives in permanent $3 \mathrm{~T} 3$ and three human primary fibroblast cultures $\mathrm{J}$ Biomed Mater Res. 1998;41:474-80.

Geurtsen W, Spahl W, Leyhausen G. Residual monomer/additive release and variability in cytotoxicity of light-curing glass-ionomer cements and compomers. J Dent Res. 1998;77(12):2012-9.

Geurtsen W, Spahl W, Muller K, Leyhausen G. Aqueous extracts from dentine adhesives contain cytotoxic chemicals. J Biomed Mater Res. 1999;48:772-7.

Gilmore TD. The Rel/NF-kappaB signal transduction pathway: introduction. Oncogene. 1999;18(49):6842-4.

Goldberg F, Massone EJ, Spielberg C. Evaluation of the dentinal bridge after pulpotomy and calcium hydroxide dressing. J Endod. 1984;10(7):318-20.

Goldberg M, Smith A. Cells and extracellular matrices of dentin and pulp. A biological basis for repair and tissue engineering. Crit Rev Oral Biol Med. 2004;15:13-27.

Goodis H. History of pulp biology. In: Hargreaves K, Goodis H, editors. Seltzer and Bender's Dental Pulp. 1 ed. Carol Stream: Quintessence publishing co; 2002. p. 1-11.

Grobler SR, Olivier A, Moodley D, Kotze TWW. Cytotoxicity of two concentrations of a dentine bonding agent on mouse 3T3 and human pulp fibroblast cell-lines. SADJ. 2004;59(9):368-72.

Guo MK, Messer HH. A comparison of $\mathrm{Ca} 2+-, \mathrm{Mg} 2+-\mathrm{ATPase}$ and alkaline phosphatase activities of rat incisor pulp. Calcif Tissue Res. 1978;26(1):33-8.

Gusman H, Santana RB, Zehnder M. Matrix metalloproteinase levels and gelatinolytic activity in clinically healthy and inflamed human dental pulps. Eur J Oral Sci. 2002;110:353-7.

Gutierrez-Venegas G, Maldonado-Frias S, Ontiveros-Granados A, Kawasaki-Cardenas P. Role of p38 in nitric oxide synthase and cyclooxygenase expression, and nitric oxide and $\mathrm{PGE}_{2}$ synthesis in human gingival fibroblasts stimulated with lipopolysaccharides. Life Sci. 2005;77(1):60-73.

Guven G, Cehreli SB, Altun C, Cehreli ZC, Serdar MA, Ural AU. The effects of one-step self-etch adhesives on the induction of oxidative stress and production of TGF-beta1 and BMP-2 by human gingival fibroblasts. J Biomater Sci Polym Ed. 2009;20(11):1597-610.

Guven G, Cehreli ZC, Ural A, Serdar MA, Basak F. Effect of mineral trioxide aggregate cements on transforming growth factor beta1 and bone morphogenetic protein production by human fibroblasts in vitro. J Endod. 2007;33(4):447-50.

Gwinnett AJ, Tay FR. Early and intermediate response of dental pulp to an acid etch techinique in vivo. Am J Dent. 1998;10:35-44.

Hahn CL, Liewehr FR. Innate immune responses of the dental pulp to caries. J Endod. 2007a;33(6):643-51.

Hahn CL, Liewehr FR. Update on the adaptive immune responses of the dental pulp. J Endod. 2007b;33(7):773-81.

Hamilton IR. Ecological basis for dental caries. In: Kuramitsu HK, Ellen RP, editors. Oral bacterial ecology: the molecular basis. Wymondham, UK: Horizon Scientific Press; 2000. 
Hanks CT, Strawn SE, Wataha JC, Craig RG. Cytotoxic effects of resin components on cultured mammalian fibroblasts. J Dent Res. 1991;70(11):1450-55.

Hanks CT, Wataha JC, Paesell RR, Strwn SE, Fat JC. Permeability of biological and syntetic molecules through dentin. Journal of oral rehabilitation. 1994;21:475-87.

Hanks CT, Wataha JC, Parsell RR, Strawn SE. Delineation of cytotoxic concentrations of two dentin bonding agents in vitro. J Endod. 1992;18:589-96.

Hannas AR, Pereira JC, Granjeiro JM, Tjäderhane L. The role of matrix metalloproteinases in the oral environment. Acta Odontol Scand. 2007;65(1):1-13.

Hashimoto M, Asai Y, Ogawa T. Separation and structural analysis of lipoprotein in a lipopolysaccharide preparation from Porphyromonas gingivalis. Int Immunol. 2004;16(10):1431-7.

Hatakeyama J, Tamai R, Sugiyama A, Akashi S, Sugawara S, Takada H. Contrasting responses of human gingival and periodontal ligament fibroblasts to bacterial cell-surface components through the CD14/Toll-like receptor system. Oral Microbiol Immunol. 2003;18(1):14-23.

He L, Nagasawa T, Ishikawa I. Production of interleukin-11 and interleukin-6 in cultured human gingival fibroblasts with the stimulation of lipopolysaccharides. Zhonghua Kou Qiang Yi Xue Za Zhi. 2007;42(1):34-6.

He Z, Zhu Y, Jiang H. Toll-like receptor 4 mediates lipopolysaccharide-induced collagen secretion by phosphoinositide3-kinase-Akt pathway in fibroblasts during acute lung injury. J Recept Signal Transduct Res. 2009;29(2):119-25.

Hebling J, Giro EM, Costa CA. Biocompatibility of an adhesive system applied to exposed human dental pulp. J Endod. 1999a;25(10):676-82.

Hebling J, Giro EMA, Costa CA. Human pulp response after an adhesive system application in deep cavities. J Dent. 1999b;27:557-64.

Heithersay GS. Calcium hydroxide in the treatment of pulpless teeth with associated pathology. J Brit Endod Soc. 1975;8:74-93.

Herlaar E, Brown Z. p38 MAPK signalling cascades in inflammatory disease. Mol Med Today. 1999;5(10):439-47.

Holland R. Histochemical response of amputes pulps to calcium hydroxide. Rev Bras Pesq Med Biol. 1971;4(1-2):83-95.

Holland R, Souza V, Nery MJ, Bernabé PFE, Filho JA, Júnior ED, et al. Calcium salts deposition in rat connective tissue after the implantation of calcium hydroxide-containing sealers. $\mathrm{J}$ Endod. 2002;28(3):173-6.

Hosokawa Y, Hosokawa I, Ozaki K, Nakae H, Murakami K, Miyake Y, et al. CXCL12 and CXCR4 expression by human gingival fibroblasts in periodontal desease. Clin Exp Immunol. 2005;141:46774.

Hse KMY, Leung SK, Wei SHY. Resin-ionomer restorative materials for children: a review. Aust Dent J. 1999;44:1-11. 
Huang FM, Chang YC. Cytotoxicity of resin-based restorative materials on human pulp cells cultures. Oral Surg Oral Med Oral Pathol Oral Radio Endod. 2002;94:361-5.

Imhof BA, Dunon D. Basic mechanism of leukocyte migration. Horm Metab Res. 1997;29(12):61421.

Inkielewicz-Stepniak I, Czarnowski W. Oxidative stress parameters in rats exposed to fluoride and caffeine. Food Chem Toxicol. 2010;48(6):1607-11.

Izumi T, Kobayashi I, Okamura K, Sakai H. Immunohistochemical study on the immunocompetent cells of the pulp in human non-carious and carious teeth. Arch Oral Biol. 1995;40:609-14.

Jiang HW, Ling JQ, Gong QM. The expression of stromal cell-derived factor 1 (SDF-1) in inflamed human dental pulp. J Endod. 2008;34(11):1351-4.

Jiang L, Zhu YQ, Du R, Gu YX, Xia L, Qin F, et al. The expression and role of stromal cell-derived factor-1alpha-CXCR4 axis in human dental pulp. J Endod. 2008;34(8):939-44.

Karin NJ. The multiple faces of CXCL12 (SDF-1alpha) in the regulation of immunity during health and disease. Leukoc Biol. 2010;88(3):463-73.

Kawai K, Takaoka T. Fluoride, hydrogen ion and HEMA release from ligth-cured GIC restoratives. Am J Dent. 2002;15:149-52.

Kendall HK, Marchal RI, Bartold PM. Nitric oxide and tissue destruction. Oral Dis. 2002;7(1):2-10.

Khabbaz MG, Anastasiadis PL, Sykaras SN. Determination of endotoxins in caries: association with pulpal pain. Int Endod J. 2000;33:132-37.

Kiechele FL, Malinski T. Nitric oxide. Biochemistry, pathophysiology, and detection. Am J Clin Pathol. 1993;100(5):567-75.

Koga T, Nishihara T, Fujiwara T, Nisizawa T, Okahashi N, Noguchi T, et al. Biochemical and immunobiological properties of lipopolysaccharide (LPS) from Bacteroides gingivalis and comparison with LPS from Escherichia coli. Infect Immun. 1985;47(3):638-47.

Koliniotou-Koumpia E, Tziafas D. Pulpal responses following direct pulp capping of healthy dog teeth with dentine adhesive systems. J Dent Res. 2005;33(8):639-47.

Lan WH, Lan W, Wang TM, Lee YL, Tseng WY, Lin CP. Cytotocixity of conventional and modified glass ionomer cements. Oper Dent. 2003;28:251-9.

Law AS, Baumgardner KR, Meller ST, Gebhart GF. Localization and changes in NADPH-diaphorase reactivity and nitric oxide synthase immunoreactivity in rat pulp following tooth preparation. J Dent Res. 1999;78(10):1585-95.

Lechner JH, Kalnitsky G. The presence of large amounts of type III collagen in bovine dental pulp and its significance with regard to the mechanism of dentinogenesis. Arch Oral Biol. 1981;26(4):265-73.

Lehmann N, Debret R, Roméas A, Magloire H, Degrange M, Bleicher F, et al. Self-etching increases matrix metalloproteinase expression in the dentin-pulp complex. J Dent Res. 2009;88(1):77-82. 
Letzelter C, Croute F, Pianezzi B, Roques C, Soleilhavoup J. Supernatant cytotoxicity and proteolytic activity of selected oral bacteria against human gingival fibroblasts in vitro. Arch Oral Biol. 1998;43(1):15-23.

Liu G, Chai C, Cui L. Fluoride causing abnormally elevated serum nitric oxide levels in chicks. Environ Toxicol Pharmacol. 2003;13(3):199-204.

Lohinai Z, Szekely A, Benedek P, Csiliag A. Nitric oxide synthase containing nerves in the cat and dog dental pulp and gingiva. Neurosci Lett. 1997;227:91-4.

Love RM, Jenkinson HF. Invasion of dentinal tubules by oral bactéria. Crit Rev Oral Biol Med. 2002;13:171-83.

Mantellini MG, Botero T, Yaman P, Dennison JB, Hanks CT, Nör JE. Adhesive resin and the hydrophilic monomer HEMA induce VEGF expression on dental pulp cells and macrophages. Dent Mat. 2006;22:434-40.

Mantellini MG, Botero TM, Yaman P, Dennison JB, Hanks CT, Nör JE. Adhesive resin induces apoptosis and cell-cycle arrest of pulp cells. J Dent Res. 2003;82(8):592-6.

Martinez E, Araujo V. In vitro immunoexpression of extracellular matrix proteins in dental pulpal and gingival human fibroblasts. Int Endod J. 2004;37(11):749-55.

Matsushima K, Ohbayashi E, Takeuchi H, Hosoya S, Abiko Y, Yamazaki M. Stimulation of interleukin-6 production in human dental pulp cells by peptidoglycans from Lactobacillus casei. $\mathrm{J}$ Endod. 1998;24(4):252-5.

Mazzoni A, Pashley DH, Nishitani Y, Breschi L, Mannello F, Tjäderhane L, et al. Reactivation of inactivated endogenous proteolytic activities in phosphoric acid-etched dentine by etch-and-rinse adhesives. Biomaterials. 2006;27(25):4470-6.

Melin M, Joffre-Romeas A, Farges JC, Couble ML, Magloire H, Bleicher F. Effects of TGFbeta1 on dental pulp cells in cultured human tooth slices. J Dent Res. 2000;79(9):1689 -96.

Minamikawa H, Deyama Y, Nakamura K, Yoshimura Y, Kaga M, Suzuki K, et al. Effect of mineral trioxide aggregate on rat clonal dental pulp cells: expression of cyclooxygenase- 2 mRNA and inflammation-related protein via nuclear factor kappa B signaling system. J Endod. 2009;35(6):843-6.

Mitchell OF, Shankwalker GB. Osteogenic potencial of calcium hydroxide and other materials in soft tissue and bone wounds. J Dent Res. 1958;37:1157-63.

Modena KC, Casas-Apayco LC, Atta MT, Costa CA, Hebling J, Sipert CR, et al. Cytotoxicity and biocompatibility of direct and indirect pulp capping materials. J Appl Oral Sci. 2009;17(6):544-54. Montenegro MR, Franco M. Patologia: Processos Gerais. 4 ed. São Paulo: Atheneu; 2008.

Morandini AC, Sipert CR, Gasparoto TH, Greghi SL, Passanezi E, Rezende ML, et al. Differential production of macrophage inflammatory protein-1alpha, stromal-derived factor-1, and IL- 6 by human cultured periodontal ligament and gingival fibroblasts challenged with lipopolysaccharide from $P$. gingivalis. J Periodontol. 2010;81(2):310-7.

Morandini AC, Sipert CR, Ramos-Junior ES, Brozoski DT, Santos CF. Periodontal ligament and gingival fibroblasts participate in the production of TGF- $\beta$, interleukin (IL)-8 and IL-10. Braz Oral Res. 2011;25(2):157-62. 
Mosmann T. Rapid calorimetric assay for cellular growth and survival: application to proliferation and citotoxicity assays. J Immunol Methods. 1983;65(1-2):55-63.

Mount GJ. Glass-ionomer cements: past, present and future. Oper Dent. 1994;19:82-90.

Mukaida N, Okamoto S, Ishikawa Y, Matsushima K. Molecular mechanism of interleukin-8 gene expression. J Leukoc Biol. 1994;56:554-8.

Nagaoka S, Tokuda M, Sakuta T, Taketoshi Y, Tamura M, Takada H. Interleukin-8 gene expression by human dental pulp fibroblast in cultures stimulated with Prevotella intermedia lipopolysaccharide. J Endod. 1996;22(1):9-12.

Nakane A, Yoshida T, Nakata K, Horiba N, Nakamura H. Effects of lipopolysaccharides on human dental pulp cells. J Endod. 1995;21(3):128-30.

Närhi M, Hirvonen T. Functional changes in cat pulp nerve activity after thermal and mechanical injury of the pulp. Proc Finn Dent Soc. 1983;79:162-7.

Nasjleti CE, Castelli WA, Caffesse RG. Effects of composite restorations on the periodontal membrane of monkeys. J Dent Res. 1983;62:75-8.

Nathan C. Nitric oxide as a secretory product of mammalian cells. FASEB J. 1992;6:3051-64.

Navarro MFL, Pascotto RC. Cimentos de ionômero de vidro: aplicações clínicas em odontologia Série EAP-APCD ed. São Paulo: Artes Médicas; 1998.

O'Boskey FJ, Panagakos FS. Cytokines stimulate matrix metalloproteinase production by human pulp cells during long-term culture. J Endod. 1998;24(1):7-10.

Ogura N, Tobe M, Sakamaki H, Nagura H, Abiko Y, Kondoh T. Tumor necrosis factor-alpha increases chemokine gene expression and production in synovial fibroblasts from human temporomandibular joint. J Oral Pathol Med. 2005;34(6):357-63.

Okiji T. Pulp as a connective tissue. In: Hargreaves K, Goodis H, editors. Seltzer and Bender's Dental Pulp. Carol Stream: Quintessence Publishing Co; 2002. p. 95-122.

Olgart L, Edwall L, Gazelius B. Involvement of afferent nerves in pulpal blood-flow reactions in response to clinical and experimental procedures in the cat. Arch Oral Biol. 1991;36:575-81.

Olgart L, Kostouros GDE, L. Local actions of acetylcholine on vasomotor regulation in rat incisor pulp. Acta Physiol Scand 1996;158:311-6.

Olmez A, Oztas N, Basak F, Sabuncuoglu B. A histopathologic study of direct pulp-capping with adhesive resins. Oral Surg Oral Med Oral Pathol Oral Radiol Endod. 1998;86(1):98-103.

Orsini G, Mazzoni A, Orciani M, Putignano A, Procaccini M, Falconi M, et al. Matrix metalloproteinase-2 expression induced by two different adhesive systems on human pulp fibroblasts. J Endod. 2011;37(12):1663-7.

Oussaief L, Ramírez V, Hippocrate A, Arbach H, Cochet C, Proust A, et al. NF-kappaB-mediated modulation of inducible nitric oxide synthase activity controls induction of the Epstein-Barr virus productive cycle by transforming growth factor beta 1. J Virol. 2011;85(13):6502-12.

Palmer G, Anstice HM, Pearson GJ. The effect of curing regime on the release of hydroxyetil methacrylate (HEMA) from resin-modified glass-ionomer cements. J Dent. 1999;27:303-11. 
Palmqvist P, Lundberg P, Lundgren I, Hanstrom L, Lerner UH. IL-1beta and TNF-alpha regulate IL6-type cytokines in gingival fibroblasts. J Dent Res. 2008;87(6):558-63.

Park BS, Song DH, Kim HM, Choi BS, Lee H, Lee JO. The structural basis of lipopolysaccharide recognition by the TLR4-MD-2 complex. Nature. 2009;458(7242):1191-5.

Parks WC, Wilson CL, López-Boado YS. Matrix metalloproteinases as modulators of inflammation and innate immunity. Nat Rev Immunol. 2004;4(8):617-29.

Pashley DH. Consideration of dentin permeability in cytotocixity testing. Int Endod J. 1988;21:14354.

Pashley DH, Walton RE, Slavkin HC. Histology and physiology of the dental pulp. In: Ingle JI, Bakland LK, editors. Endodontics. 5 ed. Hamilton: BC Decker Inc; 2002. p. 25-61.

Pereira JC. Tratamentos conservadores da vitalidade pulpar: princípios biológicos e clínicos. Biodonto. 2004;2(2):1-100.

Pereira JC, Segala AD, Costa CA. Human pulpal response to direct pulp capping with an adhesive system. Am J Dent. 2000;13(3):139-47.

Piattelli A, Rubini C, Fioroni M, Tripodi D, Strocchi R. Transforming growth factor-beta 1 (TGF-beta 1) expression in normal healthy pulps and in those with irreversible pulpitis. Int Endod J. 2004;37(2):114-9.

Rakich DR, Wataha JC, Lefebvre CA, Weller RN. Effect of dentin bonding agents on the secretion of inflammatory mediators from macrophages. J Endodon. 1999;25(2):114-7.

Ravanti L, Hakkinen L, Larjava H, Saarialho-Kere U, Foschi M, Han J. Transforming growth factorbeta induces collagenase- 3 expression by human gingival fibroblasts via p38 mitogen-activated protein kinase. J Biol Chem 1999;274(52):292-300.

Reyes-Carmona JF, Santos AR, Figueiredo CP, Felippe MS, Felippe WT, Cordeiro MM. In vivo host interactions with mineral trioxide aggregate and calcium hydroxide: inflammatory molecular signaling assessment. J Endod. 2011;37(9):1225-35.

Ricart BG, John B, Lee D, Hunter CA, Hammer DA. Dendritic cells distinguish individual chemokine signals through CCR7 and CXCR4. J Immunol. 2011;186(1):53-61.

Rietschel ET, Brade H, Holst O, Brade L, Muller-Loennies S, Mamat U, et al. Bacterial endotoxin: Chemical constitution, biological recognition, host response, and immunological detoxification. Curr Top Microbiol Immunol. 1996;216:39-81.

Rueggeberg FA, Craig RG. Correlation of parameters used to estimate monomer conversion in a ligth cured composite. J Dent Res. 1988;67:932-7.

Rueggeberg FA, Margeson DH. The effect of oxygen inhibition on an unfilled/filled composite system. J Dent Res. 1990;69:1652-58.

Santos CF, Caprio MA, Oliveira EB, Salgado MC, Schippers DN, Munzenmaier DH, et al. Functional role, cellular source, and tissue distribution of rat elastase-2, an angiotensin II-forming enzyme. Am J Physiol Heart Circ Physiol 2003;285(2):H775-83. 
Santos CF, Oliveira EB, Salgado MC, Greene AS. Molecular cloning and sequencing of the cDNA for rat mesenteric arterial bed elastase-2, an angiotensin II-forming enzyme. J Cardiovasc Pharmacol. 2002;39(5):628-35.

Schall T, Bacon K, Camp R, Kaspari J, Goeddel D. Human macrophage inflammatory protein alpha (MIP-1 alpha) and MIP-1 beta chemokines attract distinct populations of lymphocytes. J Exp Med. 1993;177(6):1821-6.

Schmalz G, Schuster U, Schweikl H. Influence of metals on IL-6 release in vitro. Biomaterials. 1998;19(18):1689-94.

Schmalz G, Schweikl H, Hiller K-A. Release of prostaglandin E2, IL-6 and IL-8 from human oral epithelial culture models after exposure to compounds of dental materials. Eur J Oral Sci. 2000;108:442-8.

Schroder U. Effects of calcium hydroxide-containing pulp-capping agents on pulp cell migration, proliferation, and differentiation. J Dent Res. 1985;64(Spec $\left.\mathrm{n}^{\circ}\right): 541-8$.

Schulz K, Kerber S, Kelm M. Reevaluation of the Griess method for determining NO/NO2- in aqueous and protein-containing samples. Nitric Oxide. 1999;3(225-34).

Sengün A, Yalçın M, Ülker HE, Öztürk B, Hakkı SS. Cytotoxicity evaluation of dentin bonding agents by dentin barrier test on 3-dimensional pulp cells. Oral Surg Oral Med Oral Pathol Oral Radiol Endod. 2011;112(3):e83-8.

Shawkat ES, Shortall AC, Addison O, Palin WM. Oxygen inhibition and incremental layer bond strengths of resin composites. Dent Mater. 2009;25(11):1338-46.

Sidhu SK, Watson TF. Resin-modified glass ionomer materials. A status report for the American Journal of Dentistry. Am J Dent. 1995;8:59-67.

Silva AC, Faria MR, Fontes A, Campos MS, Cavalcanti BN. Interleukin-1 beta and interleukin-8 in healthy and inflamed dental pulps. J Appl Oral Sci. 2009;17(5):527-32.

Silva LPN, Issa JPM, Del Bel EA. Action of nitric oxide on healthy and inflamed human dental pulp tissue. Micron 2008;39:797-801.

Simon SR, Berdal A, Cooper PR, Lumley PJ, Tomson PL, Smith AJ. Dentin-pulp complex regeneration: from lab to clinic. Adv Dent Res. 2011;23(3):340-5.

Sipert CR. Produção de MIP-1 alfa e SDF-1 por fibroblastos de polpa dental humana em cultura frente ao desafio com Enterococcus faecalis inativado por calor. Bauru: Universidade de São Paulo; 2007.

Sipert CR, Moraes IG, Bernardinelli N, Garcia RB, Bramante CM, Gasparoto TH, et al. Heat-killed Enterococcus faecalis alters nitric oxide and CXCL12 production but not CXCL8 and CCL3 production by cultured human dental pulp fibroblasts. J Endod. 2010;36(1):91-4.

Siqueira Jr JF. Mecanismos de defesa do hospedeiro. In: Siqueira Jr JF, Dantas CJS, editors. Mecanismos celulares e moleculares da inflamação. Rio de Janeiro: Medsi Editora Médica e Científica Ltda; 2000.

Slavkin HC. The nature and nurture of epithelial-mesenchymal interactions during tooth morphogenesis. J Biol Buccale. 1978;6:189. 
Smith AJ, Garde C, Cassidy N, Ruch IV, Lesot H. solubilization of dentine extracellular matrix by calcium hydroxide. J Dent Res. 1995;74:829.

Souza Costa CA, Vaerten MA, Edwards CA, Hanks CT. Cytotoxic effects of current dental adhesive systems on immortalized odontoblast cell line MDPC-23. Dent Mat. 1999;15:434-41.

Souza PPC, Aranha AMF, Hebling J, Giro EMA, Souza Costa CA. In vitro cytotoxicity and in vivo biocompatibility of contemporary resin-modified glass-ionomer cements. Dent Mat. 2006;22:838-44.

Stanislawski L, Daniau X, Lauti A, Goldberg M. Factors responsible for pulp cell cytotoxicity induced by resin-modified glass-ionomer cements. J Biomed Mater Res. 1999;48:277-88.

Stanley HR, Going RE, Chauncey HH. Human pulp response to acid pretreatment of dentin and to composite restoration. J Am Dent Assoc. 1975;91:817-25.

Stanley HR, Pameijer CH. Dentistry's friend: calcium hydroxide. Oper Dent. 1997;22:1-3.

Stanley HR, Swerdlow H, Buonocore MG. Pulp reactions to anterior restorative materials. J Am Dent Assoc. 1967;75:132-41.

Staquet MJ, Durand SH, Colomb E, Romeas A, Vincent C, Bleicher F, et al. Different roles of odontoblasts and fibroblasts in immunity. J Dent Res. 2008;87(3):256-61.

Sterin-Borda L, Furlan C, Reina S, Orman B, Borda E. Differential signalling pathways involved in cholinoceptor-dependent stimulation of nitric oxide isoforms in dental pulp. Int Endod J. 2007;40:54452 .

Stoyanova II, Lazarov NE. Localization of nitric oxide synthase in rat trigeminal primary afferent neurons using NADPH-diaphorase histochemistry. J Mol Histol. 2005;36(3):187-93.

Sulkala M, Larmas M, Sorsa T, Salo T, Tjäderhane L. The localization of matrix metalloproteinase-20 (MMP-20, Enamelysin) in mature human teeth. J Dent Res. 2002;81:603-7.

Sulkala M, Wahlgren J, Larmas M, Sorsa T, Teronen O, Salo T, et al. The effects of MMP inhibitors on human salivary MMP activity and caries progression in rats. J Dent Res. 2001;80:1545-9.

Takahashi K, Takashiba S, Nagai A, Takigawa M, Myoukai F, Kurihara H, et al. Assessment of interleukin-6 in the pathogenesis of periodontal disease. J Periodontol. 1994;65:147-53.

Tamura M, Tokuda M, Nagaoka S, Takada H. Lipopolysaccharides of Bacteroides intermedius (Prevotella intermedia) and Bacteroides (Porphyromonas) gingivalis induce interleukin- 8 gene expression in human gingival fibroblast cultures. Infect Immun. 1992;60(11):4932-7.

Taub DD, Oppenheim JJ. Chemokines, inflammation and the immune system. Ther Immunol. 1994;1:229-46.

Tay FR, Gwinnett AJ, Pang KM, Wei SHY. Structural evidence of a sealed tissue interface with totaletch wet-bonding techinique in vivo. J Dent Res. 1994;73:629-36.

Tay FR, Pashley DH, Loushine RJ, Weller RN, Monticelli F, Osorio R. Self-etching adhesives increase collagenolytic activity in radicular dentin. J Endod. 2006;32(9):862-8.

Telles PD, Hanks CT, Machado MA, Nor JE. Lipoteichoic acid up-regulates VEGF expression in macrophages and pulp cells. J Dent Res. 2003;82(6):466-70. 
Tjäderhane L. The mechamism of pulpal wound healing. Aust Endod J. 2002;28(2):68-74.

Tokuda M, Nagaoka S, Torii M. Interleukin-10 inhibits expression of interleukin-6 and -8 mRNA in human dental pulp cell cultures via nuclear factor-kappaB deactivation. J Endod. 2002;28:177-80.

Tokuda M, Sakuta T, Fushuku A, Torii M, Nagaoka S. Regulation of interleukin-6 expression in human dental pulp cell cultures stimulated with Prevotella intermedia lipopolysaccharide. J Endod. 2001;27(4):273-7.

Torneck CD, Moe H, Howley TP. The effect of calcium hydroxide on porcine pulp fibroblasts in vitro. J Endod. 1983;9(4):131-6.

Tronstad L, Andreasen JO, Hasselgren G, Kristerson L, Riis I. pH changes in dental tissues after root canal filling with calcium hydroxide. J Endod. 1981;7:17-21.

Trowbridge H. Histology of pulpal inflammation. In: Hargreaves K, Goodis H, editors. Seltzer and Bender's Dental Pulp. Carol Stream: Quintessence publishing Co; 2002. p. 227-45.

Trubiani O, Cataldi A, De Angelis F, D'Arcangelo C, Caputi S. Overexpression of interleukin-6 and 8 , cell growth inhibition and morphological changes in 2-hydroxyethyl methacrylate-treated human dental pulp mesenchymal stem cells. Int Endod J. 2012;45(1):19-25.

Tsai CH, Chen YJ, Huang FM, Su YF, Chang YC. The upregulation of matrix metalloproteinase-9 in inflamed human dental pulps J Endod. 2005;31(12):860-2.

Tsunawaki S, Sporn M, Ding A, Nathan C. Deactivation of macrophages by transforming growth factor-beta. Nature. 1988;334(6179):260-2.

Tziafas D, Papadimitriou S. Role of exogenousTGF-beta in induction of reparative dentinogenesis in vivo. Eur J Oral Sci. 1998;106(Suppl.1):192-6.

Visse R, Nagase H. Matrix metalloproteinases and tissue inhibitors of metalloproteinases: structure, function and biochemistry. Circ Res. 2003;92:827-39.

Wataha JC. Priciples of biocompatibility for dental practioners. J Prothet Dent. 2001;86(2):203-9.

Weinmann W, Thalacker C, Guggenberger R. Siloranes in dental composites. Dent Mater. 2005;21:68-74.

Williams D. Revisiting the definition of biocompatibility. Med Device Technol. 2003;14(8):10-3.

Xie D, Brantley BM, Culbertson G, Wang G. Mechanical properties and microstructures of glassionomer cements. Dent Mat. 2000;16:129-38.

Yamaji Y, Kubota T, Sasaguri K, Sato S, Suzuki Y, Kumada H, et al. Inflammatory cytokine gene expression in human periodontal ligament fibroblasts stimulated with bacterial lipopolysaccharides. Infect Immun. 1995;63(9):3576-81.

Yang HM, Li FY, Chai JK, Yu Y, Cao WH, Jing S, et al. Regulative effect of lipopolysaccharide on the mRNA expression of procollagen type I and type III and collagenase of normal human skin fibroblasts and its significance. Zhonghua Yi Xue Za Zhi. 2007;87(32):2268-70.

Yang L, Huang F, Lin C, Liu C, Lai C, Chang Y. Induction of interleukin-8 gene expression by blackpigmented Bacteroides in human pulp fibroblasts and osteoblasts. Int Endod J 2003;36(11):774-9. 
Yang L, Tsai C, Huang F, Liu C, Lai C, Chang Y. Induction of interleukin-6 gene expression by proinflammatory cytokines and black-pigmented Bacteroides in human pulp cell cultures. Int Endod J. 2003;36(5):352-7.

Yang LC, Tsai CH, Huang FM, Liu CM, Lai CC, Chang YC. Induction of interleukin-6 gene expression by pro-inflammatory cytokines and black-pigmented Bacteroides in human pulp cell cultures. Int Endod J. 2003;36(5):352-7.

Yiu CKY, Tay FR, King NM, Pashley DH. Interaction of resin-modified glass-ionomer cements with moist dentine. J Dent. 2004;32:521-30.

Zehnder M, Delaleu N, Du Y, Bickel M. Cytokine gene expression-part of host defense in pulpitis. Cytokine. 2003;22(3-4):84-8. 


$$
E
$$





\section{ÓxIDo Nítrico}

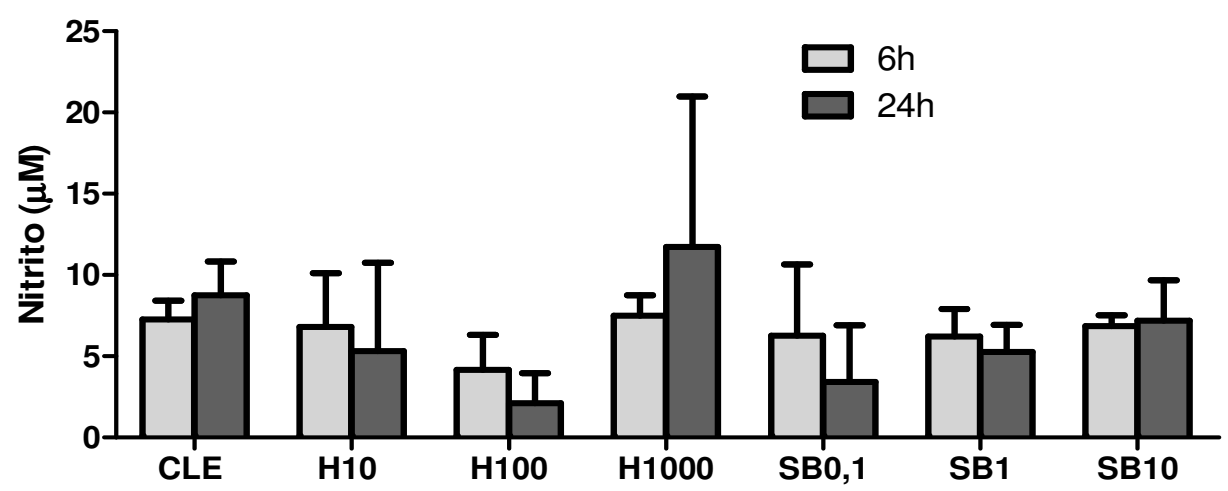

Figura 21- Quantidade de nitrito produzida por fibroblastos de polpa dental humana estimulados pelos materiais H10 (HEMA 10 nM), H100 (HEMA 100 nM), H1000 (HEMA 1000 nM), SB 0,1 (Single Bond 1:10.000), SB 1 (Single Bond 1:1.000), SB 10 (Single Bond 1:100) nos períodos de 6 e 24 horas. Valores representativos das médias \pm o desvio padrão. $\mathrm{O}$ ensaio foi realizado em triplicata.

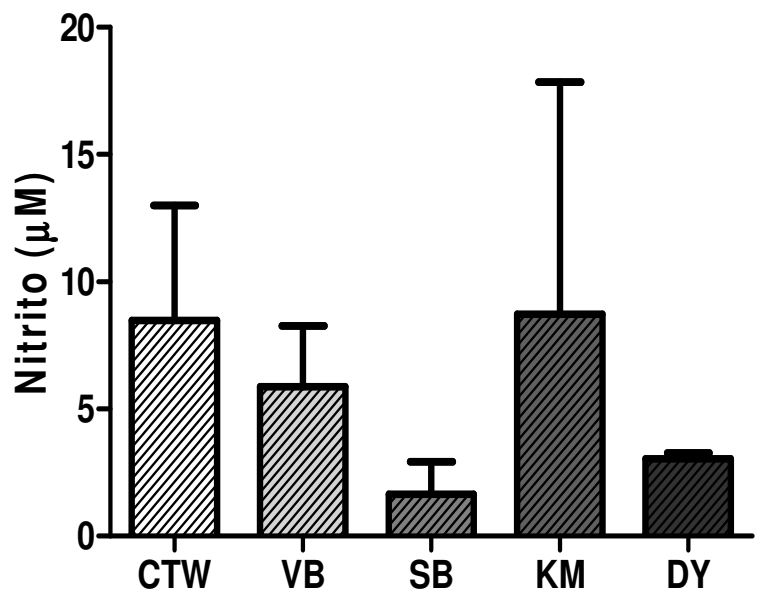

Figura 22- Quantidade de nitrito produzida por fibroblastos de polpa dental humana estimulados pelos materiais VB (Vitrebond), SB (Single Bond), KM (Ketac Molar), DY (Dycal) no período de 24 horas. Valores representativos das médias \pm o desvio padrão. O ensaio foi realizado em triplicata. 


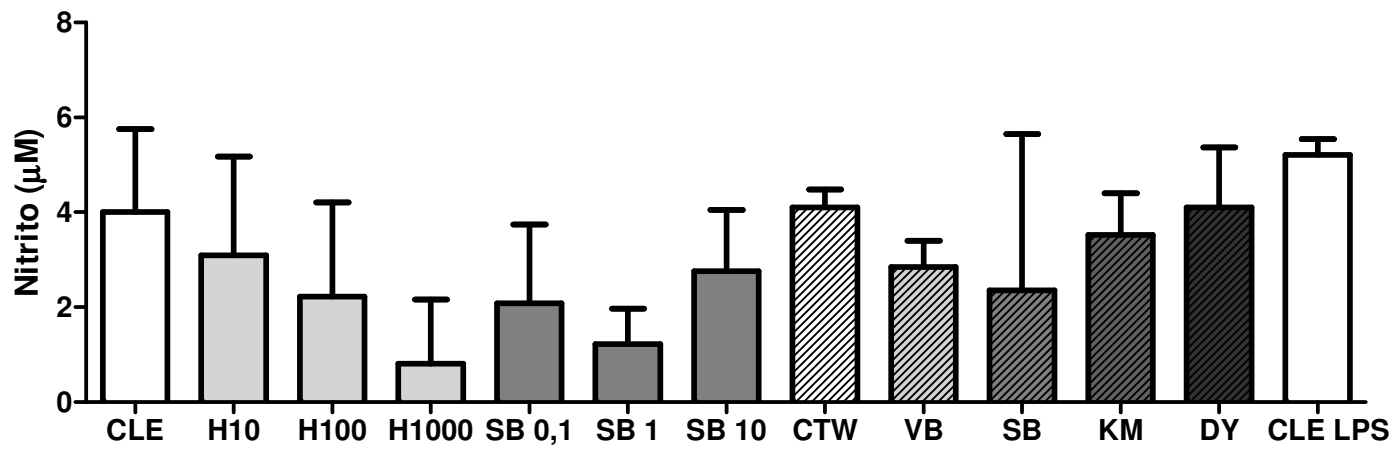

Figura 23- Quantidade de nitrito produzida por fibroblastos de polpa dental humana estimulados pelos materiais H10 (HEMA 10 nM), H100 (HEMA 100 nM), H1000 (HEMA 1000 nM), SB 0,1 (Single Bond 1:10.000), SB 1 (Single Bond 1:1.000), SB 10 (Single Bond 1:100) comparado ao seu grupo controle CLE e VB (Vitrebond), SB (Single Bond), KM (Ketac Molar), DY (Dycal) comparado ao seu grupo controle CTW seguidos por LPS de $E$. coli no período de 24 horas. Valores representativos das médias \pm o desvio padrão. $\mathrm{O}$ ensaio foi realizado em triplicata. 


\section{EXPRESSÃO GÊNICA PARA PRÓ-COLÁGENO TIPO I}

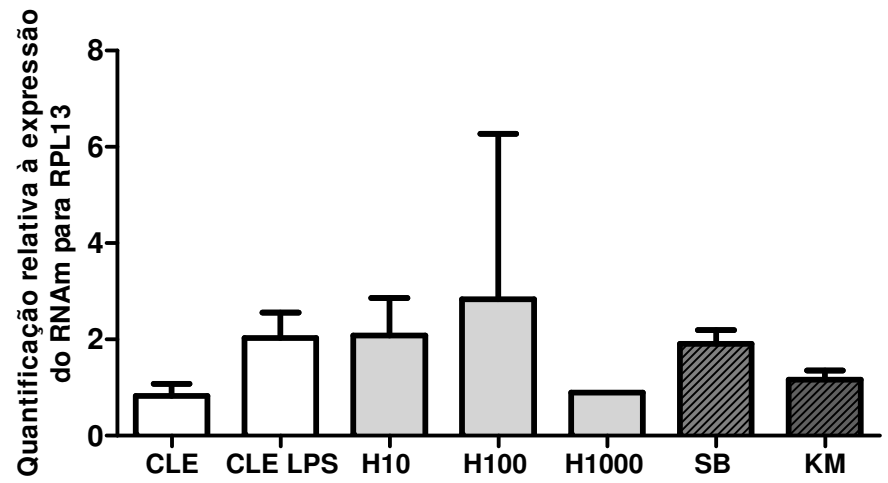

Figura 24- Expressão do RNAm para pró-colágeno tipo I por fibroblastos de polpa dental humana estimulados pelos materiais H10 (HEMA $10 \mathrm{nM}$ ), H100 (HEMA $100 \mathrm{nM}$ ), H1000 (HEMA $1000 \mathrm{nM})$, SB, KM seguidos por LPS de E.coli no período de 24 horas. Valores representativos das médias \pm o desvio padrão. O ensaio foi realizado em triplicata.

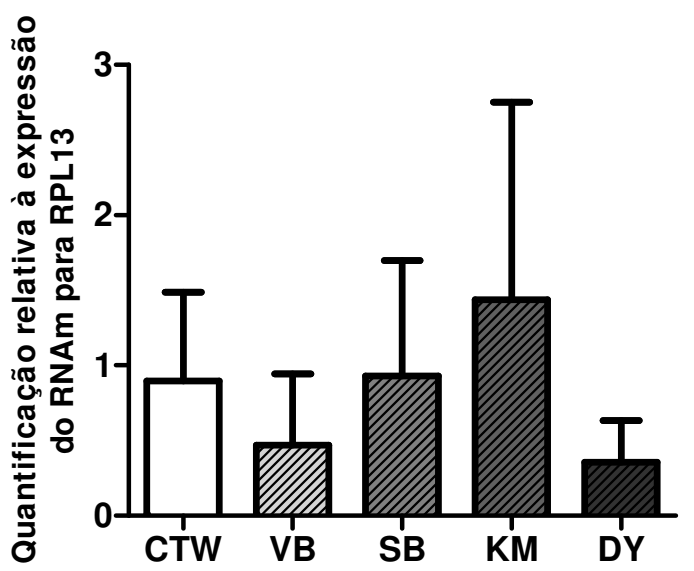

Figura 25- Expressão do RNAm para pró-colágeno tipo I por fibroblastos de polpa dental humana estimulados pelos materiais VB (Vitrebond), SB (Single Bond), KM (Ketac Molar), DY (Dycal) no período de 24 horas. Valores representativos das médias \pm o desvio padrão. $\mathrm{O}$ ensaio foi realizado em triplicata. 


\section{EXPRESSÃo GÊNICA PARA IL-6}

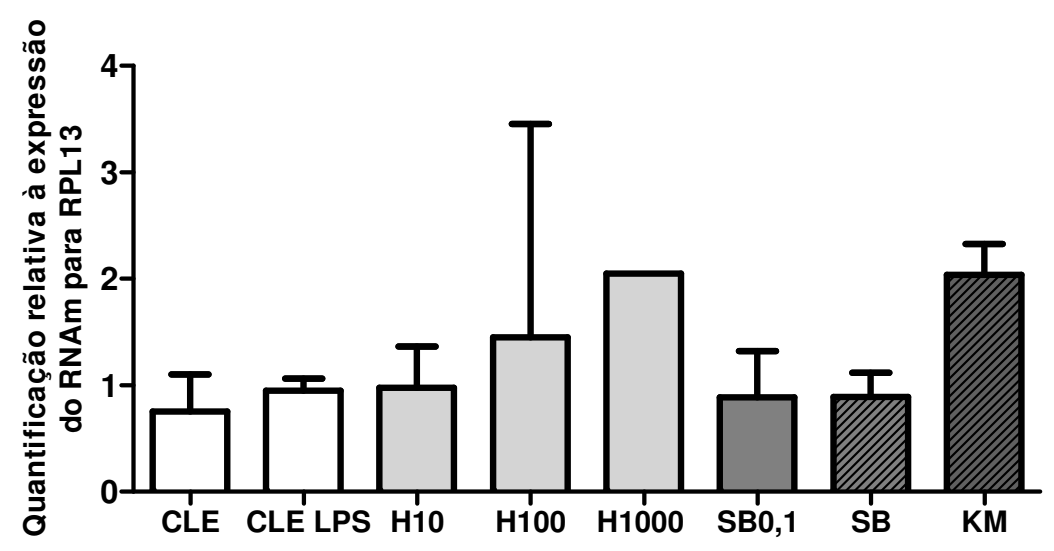

Figura 26- Expressão do RNAm para IL-6 por fibroblastos de polpa dental humana estimulados pelos materiais H10 (HEMA 10 nM), H100 (HEMA 100 nM), H1000 (HEMA 1000 nM), SB 0,1 (Single Bond 1:10.000), SB e KM seguidos por LPS de E.coli no período de 24 horas. Valores representativos das médias \pm o desvio padrão. $\mathrm{O}$ ensaio foi realizado em triplicata.

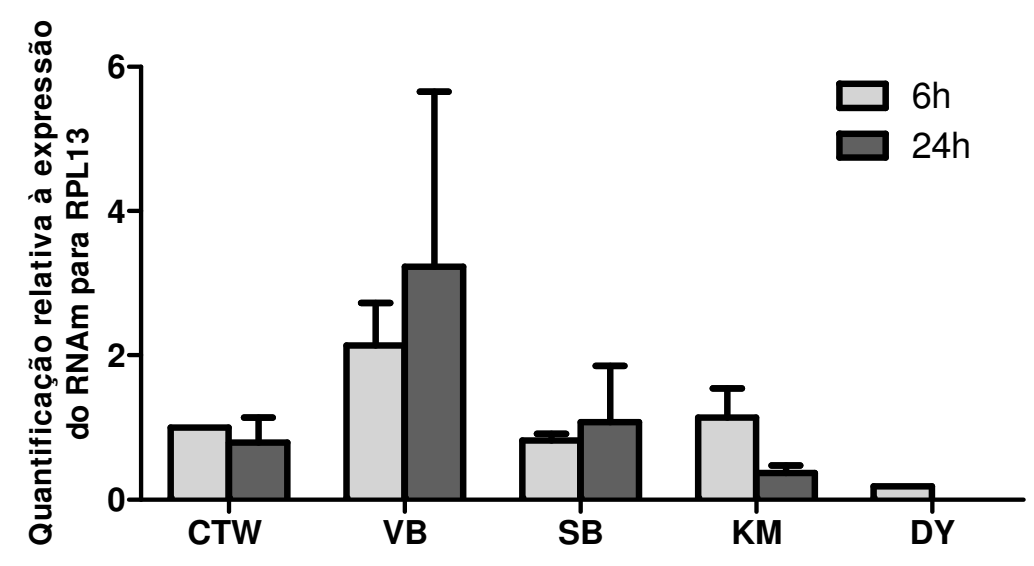

Figura 27- Expressão do RNAm para IL-6 por fibroblastos de polpa dental humana estimulados pelos materiais VB (Vitrebond), SB (Single Bond), KM (Ketac Molar), DY (Dycal) no período de 6 e 24 horas. Valores representativos das médias \pm o desvio padrão. $\mathrm{O}$ ensaio foi realizado em triplicata. 


\section{EXPRESSÃo GÊNICA PARA IL-8/CXCL8}

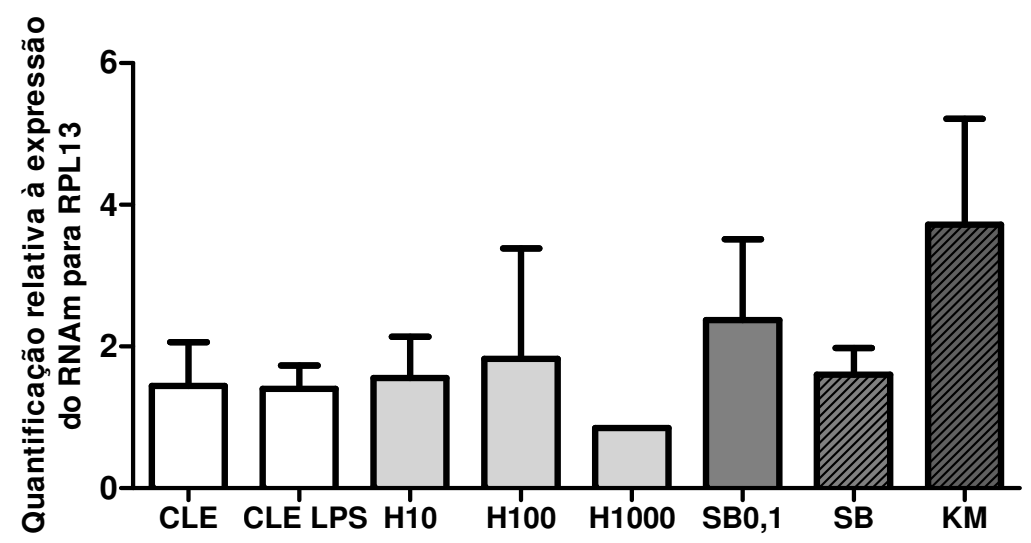

Figura 28- Expressão do RNAm para IL-8/CXCL8 por fibroblastos de polpa dental humana estimulados pelos materiais H10 (HEMA 10 nM), H100 (HEMA 100 nM), H1000 (HEMA 1000 nM), SB 0,1 (Single Bond $1: 10.000)$, SB e KM seguidos por LPS de E.coli no período de 24 horas. Valores representativos das médias \pm 0 desvio padrão. $\mathrm{O}$ ensaio foi realizado em triplicata. 


\section{DETECÇÃo DA PRODUÇÃo DE SDF-1 $\alpha /$ CXCL12}

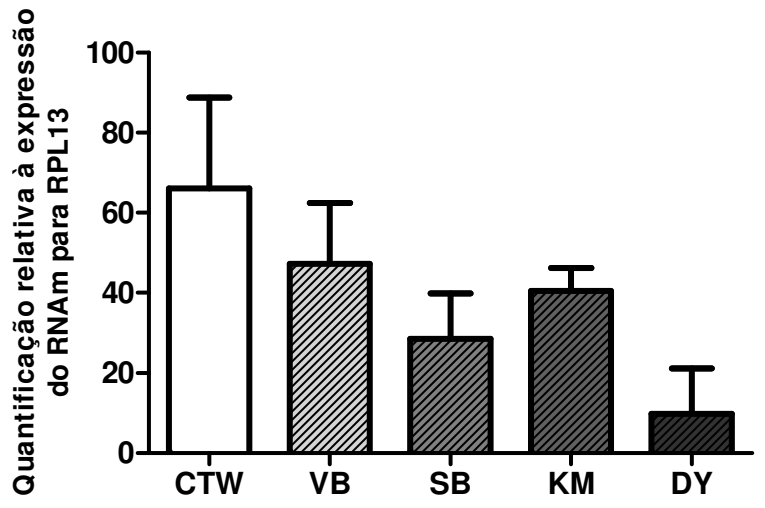

Figura 29- Produção in vitro de SDF-1 $\alpha /$ CXCL12 por fibroblastos de polpa dental humana estimulados pelos materiais VB (Vitrebond), SB (Single Bond), KM (Ketac Molar), DY (Dycal) no período de 6 horas. Valores representativos das médias \pm o desvio padrão. $\mathrm{O}$ ensaio foi realizado em duplicata. 


\section{DETECÇÃo DA PRODUÇÃo DE IL-6}

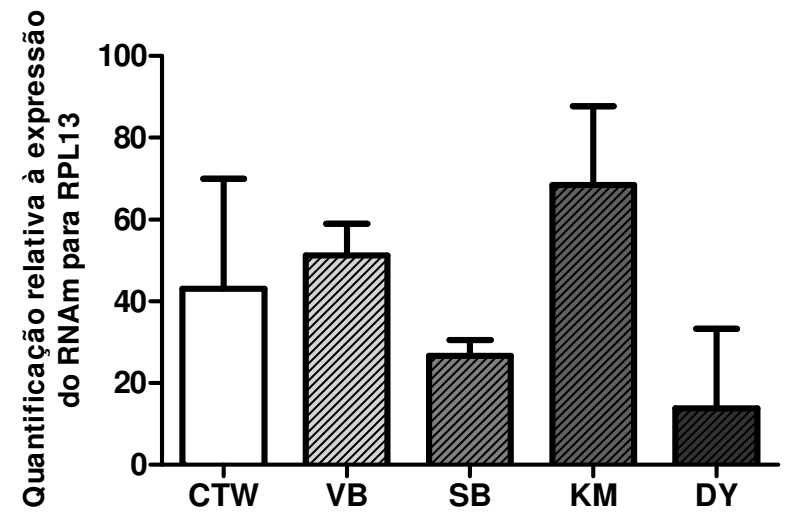

Figura 30- Produção in vitro de IL-6 por fibroblastos de polpa dental humana estimulados pelos materiais VB (Vitrebond), SB (Single Bond), KM (Ketac Molar), DY (Dycal) no período de 24 horas. Valores representativos das médias \pm o desvio padrão. $O$ ensaio foi realizado em duplicata.

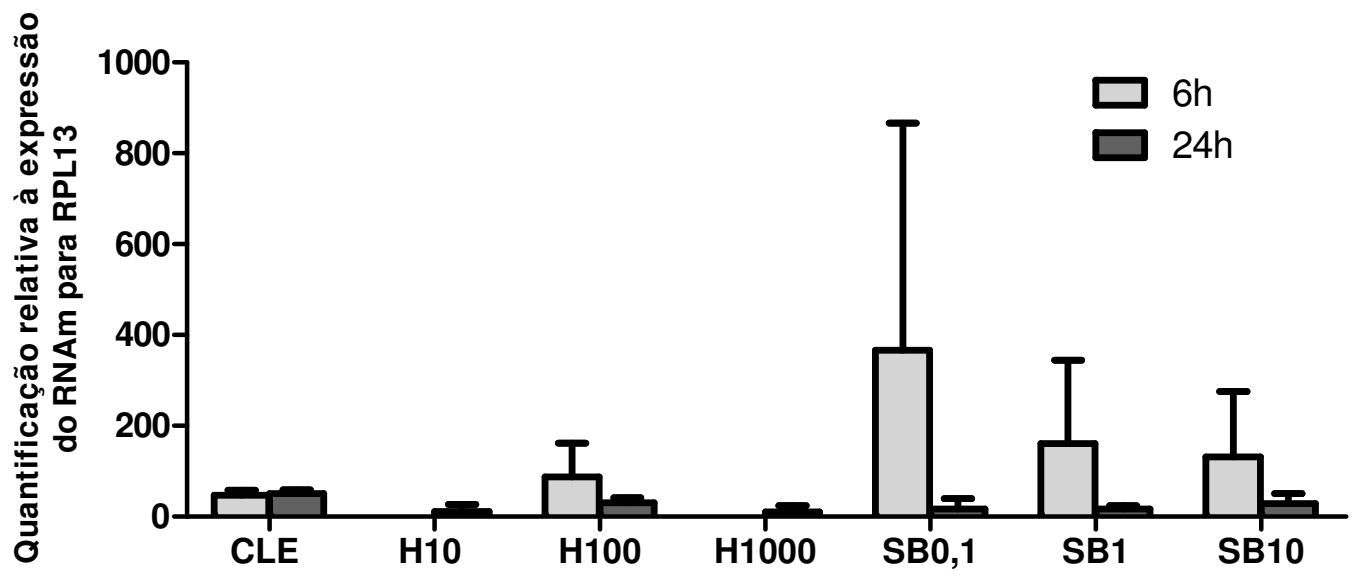

Figura 31- Produção in vitro de IL-6 por fibroblastos de polpa dental humana estimulados pelos materiais H10 (HEMA $10 \mathrm{nM}$ ), H100 (HEMA 100 nM), H1000 (HEMA $1000 \mathrm{nM}$ ), SB 0,1 (Single Bond 1:10.000), SB 1 (Single Bond 1:1.000), SB 10 (Single Bond 1:100) no período de 6 e 24 horas. Valores representativos das médias \pm o desvio padrão. $\mathrm{O}$ ensaio foi realizado em duplicata. 


\section{DETECÇÃo dA PRODUÇÃo DE IL-8/CXCL8}

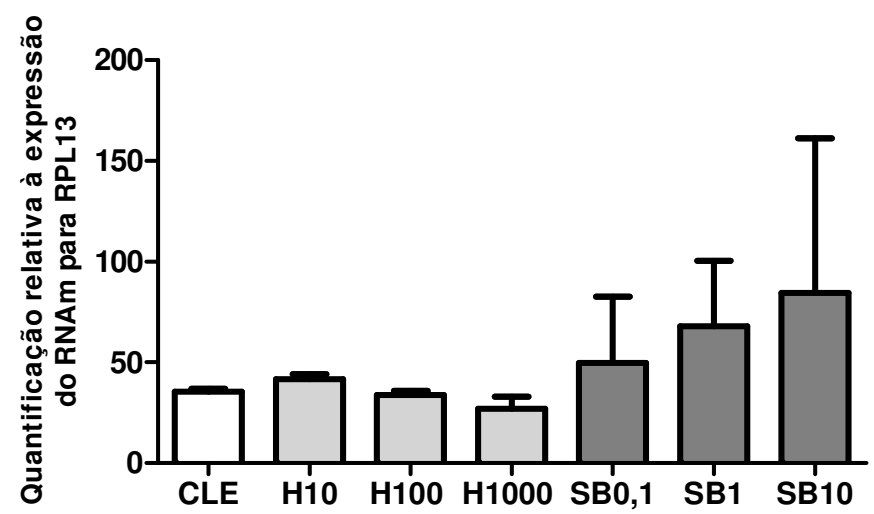

Figura 32- Produção in vitro de IL-8/CXCL8 por fibroblastos de polpa dental humana estimulados pelos materiais H10 (HEMA $10 \mathrm{nM}$ ), H100 (HEMA $100 \mathrm{nM}$ ), H1000 (HEMA $1000 \mathrm{nM}$ ), SB 0,1 (Single Bond 1:10.000), SB 1 (Single Bond 1:1.000), SB 10 (Single Bond 1:100) no período de 6 horas. Valores representativos das médias \pm o desvio padrão. $\mathrm{O}$ ensaio foi realizado em 




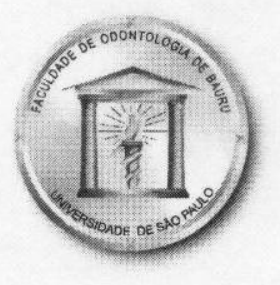

Processo $n^{\circ} 137 / 2007$

\section{Universidade de São Paulo Faculdade de Odontologia de Bauru \\ Al. Dr. Octávio Pinheiro Brisolla, 9-75 - Bauru-SP - CEP 17012-901 - C.P. 73} PABX (0XX14)3235-8000 - FAX (0XX14)3223-4679

Comitê de Ética em Pesquisa (14)3235-8356 mferrari@fob.usp.br

Bauru, 07 de novembro de 2007.

Senhora Professora,

O projeto de pesquisa encaminhado a este Comitê de Ética em Pesquisa intitulado "Produção de MIP-1 alfa e SDF-1 por fibroblastos da polpa dental humana em cultura estimulados por um sistema adesivo, CIVMR e HEMA" de autoria de Karin Cristina da Silva Modena, sob sua orientação e co-orientação da Prof ${ }^{a}$ Dr $^{a}$ Maria Teresa Atta e Prof. Dr. Carlos Ferreira dos Santos, foi enviado ao relator para avaliação.

Na reunião de 31 de outubro de 2007, o relator emitiu o seguinte parecer, que foi considerado APROVADO COM RECOMENDAÇÃO pelo Comitê:

\section{Análise e parecer do relator:}

"Os objetivos deste estudo são: avaliar a capacidade de fibroblastos de polpa dental humana em cultura quanto a produção das quimiocinas MPI-1/CCL3 e SDF-1/CXXL12 e Avaliar a liberação das quimiocinas MPI-1/CCL3 e SDF-1/CXXL12 por fibroblastos de polpa dental humana em cultura quando estimulados por um sistema adesivo, cimento de ionômero de vidro e o monômero HENA. Serão utilizados 10 dentes, recém extraídos, terceiros molares não irrompidos, de pacientes livre de doenças sistêmicas obtidos no Laboratório de fisiologia e Farmacologia Clínica da FOB/UPS. Os dentes serão doados pelos pacientes, que assinarão a doação, em formulário específico. Serão utilizados procedimentos especializados para a realização do estudo.

Observação: Por tratar de material biológico, alterar o item número de sujeitos participantes nas folhas de rosto do Ministério da Saúde."

Ressaltamos que, de acordo com o estabelecido pela Resolução $n^{\circ}$ 196/96, no Conselho Nacional de Saúde: APROVADO COM RECOMENDAÇÃO, considerando que o quesito a ser atendido não é impeditivo para o início da pesquisa, devendo o pesquisador encaminhar as modificações sugeridas ou documentos solicitados, para complementação de análise do Projeto.

Atenciosamente,

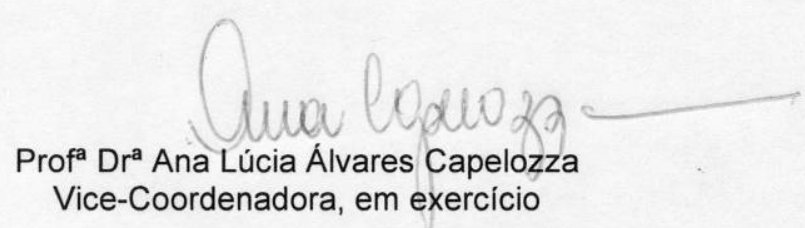

Prof ${ }^{a}$ Dr ${ }^{\mathrm{a}}$ Maria Fidela de Lima Navarro

Docente do Departamento de Dentística, Endodontia e Materiais Dentários 


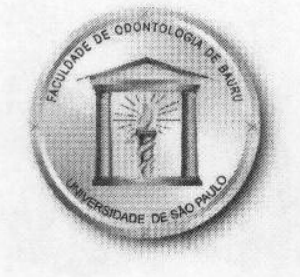

Processo $n^{\circ} 137 / 2007$

Bauru, 29 de fevereiro de 2008.

\section{Universidade de São Paulo \\ Faculdade de Odontologia de Bauru}

Al. Dr. Octávio Pinheiro Brisolla, 9-75 - Bauru-SP - CEP 17012-901 - C.P. 73

PABX (0XX14)3235-8000 - FAX (0XX14)3223-4679

Comitê de Ética em Pesquisa (14)3235-8356

mferrari@fob.usp.br

Senhora Professora,

Informamos que após o envio da documentação solicitada referente ao projeto de pesquisa encaminhado a este Comitê de Ética em Pesquisa "Produção de MIP-1 alfa e SDF-1 por fibroblastos da polpa dental humana em cultura estimulados por um sistema adesivo, CIVMR e HEMA" de autoria de Karin Cristina da Silva Modena, sob sua orientação e coorientação da Prof ${ }^{a}$ Dr $^{\mathrm{a}}$ Maria Teresa Atta e Prof. Dr. Carlos Ferreira dos Santos, foi novamente analisado e considerado APROVADO por este Colegiado, em reunião realizada no dia 26 de fevereiro de 2008.

Solicitamos que ao término do trabalho, seja enviado a este Comitê um relatório final para novo parecer, o qual será utilizado para publicação em revista científica.

Atenciosamente,

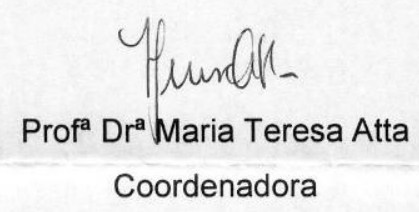

Prof $^{\mathrm{a}} \mathrm{Dr}^{\mathrm{a}}$ Maria Fidela de Lima Navarro

Docente do Departamento de Dentística, Endodontia e Materiais Dentários 


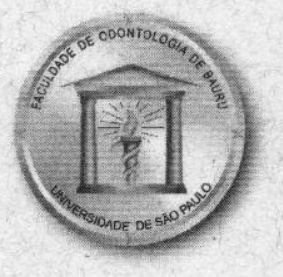

\section{Universidade de São Paulo Faculdade de Odontologia de Bauru}

Al. Dr. Octávio Pinheiro Brisolla, 9-75 - Bauru-SP - Brasil - CEP 17012-901 - C.P. 73 PABX (0XX14)3235-8000 - FAX (0XX14)3223-4679

Comitê de Ética em Pesquisa (3235-8356)

e-mail: mferrari@fob.usp.br

Of. ${ }^{\circ}$ CEP/34 2008/FOB

Proc. CEP n $137 / 2007$

Bauru, 29 de agosto de 2008.

Senhora Professora,

Informamos que após análise por este Comitê de Ética em Pesquisa em Seres Humanos, a alteração do título do projeto de pesquisa "A Produção de MIP-1 alfa e SDF-1 por fibroblastos da polpa dental humana em cultura estimulados por um sistema adesivo, CIVMR e HEMA" de autoria de Karin Cristina da Silva Modena, sob sua orientação e co-orientação da Profa $\mathrm{Dr}^{\mathrm{a}}$ Maria Teresa Atta e Prof. Dr. Carlos Ferreira dos Santos, para "Influência de materiais odontológicos na capacidade de resposta de fibroblastos cultivados de polpa dental humana e diferentes antígenos" foi aprovado considerando não ter modificado sua metodologia.

Lembramos que após o envio do trabalho concluido, este Comitê enviará o parecer final, que será utilizado para a publicação do trabalho.

Atenciosamente,

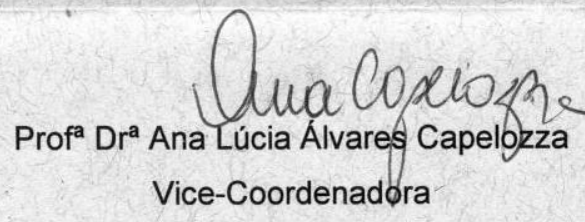

Profa Dra Maria Fidela de Lima Navarro

Docente do Departamento de Dentística; Endodontia e Materiais Dentários 


\section{TERMO DE DOAÇÃO}

$\mathrm{Eu}$

portador de $\mathrm{RG} \mathrm{n}^{\circ}$

residente à Rua (Av.)

no , na cidade de

Estado

concordo

em doar o dente extraído nesta ocasião para a pesquisa de Título: "Produção de MIP-1 alfa e SDF-1 por fibroblastos da polpa dental humana em cultura estimulados por um sistema adesivo, CIVMR e HEMA" realizada por Karin Cristina da Silva Modena, CROSP 85.298; sob orientação da Drª . Maria Fidela de Lima Navarro, CRO-SP 2.049.

A referida pesquisa tem como objetivo o estudo dos fenômenos inflamatórios das células da polpa. A minha participação consiste na doação voluntária do elemento dentário com indicação para extração e estou ciente de que a mesma é opcional e dela posso desistir a qualquer momento, sem explicar os motivos e sem comprometer meu tratamento no Laboratório de Fisiologia e Farmacologia Clínica da Faculdade de Odontologia de Bauru.

Bauru, I

Assinatura do Paciente

Pesquisador Responsável: Karin Cristina da Silva Modena

Endereço: Rua Prof. Gerson Rodrigues, 7-51, apto. 804

Bauru São Paulo CEP: 17043-535

Telefone: 14 3235-8282 